UNIVERSIDADE DE SÃO PAULO

FACULDADE DE FILOSOFIA,

LETRAS E CIÊNCIAS HUMANAS

DEPARTAMENTO DE TEORIA LITERÁRIA

E LITERATURA COMPARADA

\title{
Figuras Infernais no Teatro de Samuel Beckett
}

Cláudia Maria de Vasconcellos

Tese apresentada ao Programa de Pós-Graduação em Teoria Literária e Literatura Comparada da Faculdade de Filosofia, Letras e Ciências Humanas da Universidade de São Paulo, para a obtenção do título de Doutor em Letras.

orientador: Professor Doutor Fábio de Souza Andrade

São Paulo 
para Rubens Rusche 


\section{Agradecimentos}

A Fábio de Souza Andrade, pela amizade, pela condução serena e generosa deste doutorado, pelos excelentes cursos ministrados que acompanhei com enorme proveito.

A Rubens Rusche por partilhar suas meditações sobre a obra de Beckett em longas conversas, por suas traduções deixadas à disposição deste estudo, pela amizade e inspiração constante.

Às colegas do grupo de estudos 'Dramáticas em Cena' - Marici Salomão, Vera de Sá, Beatriz Gonçalves - que compartilham comigo o entusiasmo pelo teatro e por Bekcett.

Aos professores Jorge de Almeida e Luiz Fernando Ramos, cujas observações, por ocasião da qualificação, foram determinantes para o desenvolvimento desta tese.

À meus pais e irmãs que acompanharam este percurso sempre com interesse.

À Vera Villela, atriz beckettiana, pela amizade, pela gentil atenção cedida a este estudo, pelas conversas sobre Escher e sobre a coatividade. 
Resumo

A tese analisa as cinco primeiras peças teatrais de Beckett - Esperando Godot, Fim de Partida, A Última Fita de Krapp, Dias Felizes e Peça - e procura identificar seus procedimentos formais básicos, chamados de 'figuras infernais'. Na esteira de Adorno, o estudo da forma aqui realizado encontra na obra de Beckett uma 'reflexão' das configurações sociais e do estado paradoxal da arte dentro deste quadro. As figuras infernais - circularidade, confinamento, paradoxo, inconcludência, intermitência, dissimulação e coatividade - erigemse também como instrumental crítico para a compreensão do teatro subsecutivo de Beckett, bem como de outros gêneros explorados pelo autor.

\section{Abstract}

The thesis analyses the first five plays written by Beckett - Waiting for Godot, Endgame, Krapp's Last Tape, Happy Days and Play - aiming to identify their fundamental formal procedures, which we call here 'hellish figures'. Inspired by Adorno, our study of form finds in the work of Beckett a reflection about the social configuration and the paradoxal state of the Arts during his time. The 'hellish figures' - circularity, confinement, paradox, inconclusiveness, interminttence, dissimulation and enforcement - can be used as a critical tool to understand Beckett's other plays and writings.

Palavras-chave: Beckett, Teatro, Figuras, Escher, Coatividade 


\section{Índice}

Apresentação....................................... p.7

Esperando Godot........................................ 10

Fim de Partida............................................. 45

A Última Fita de Krapp..............................p.85

Dias Felizes................................................ 101

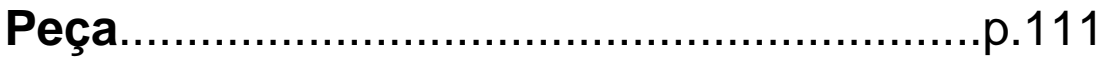

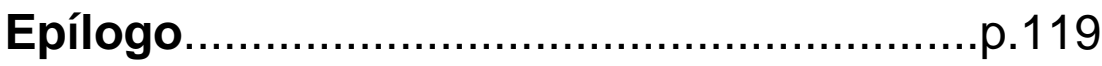

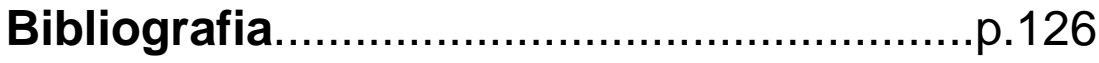




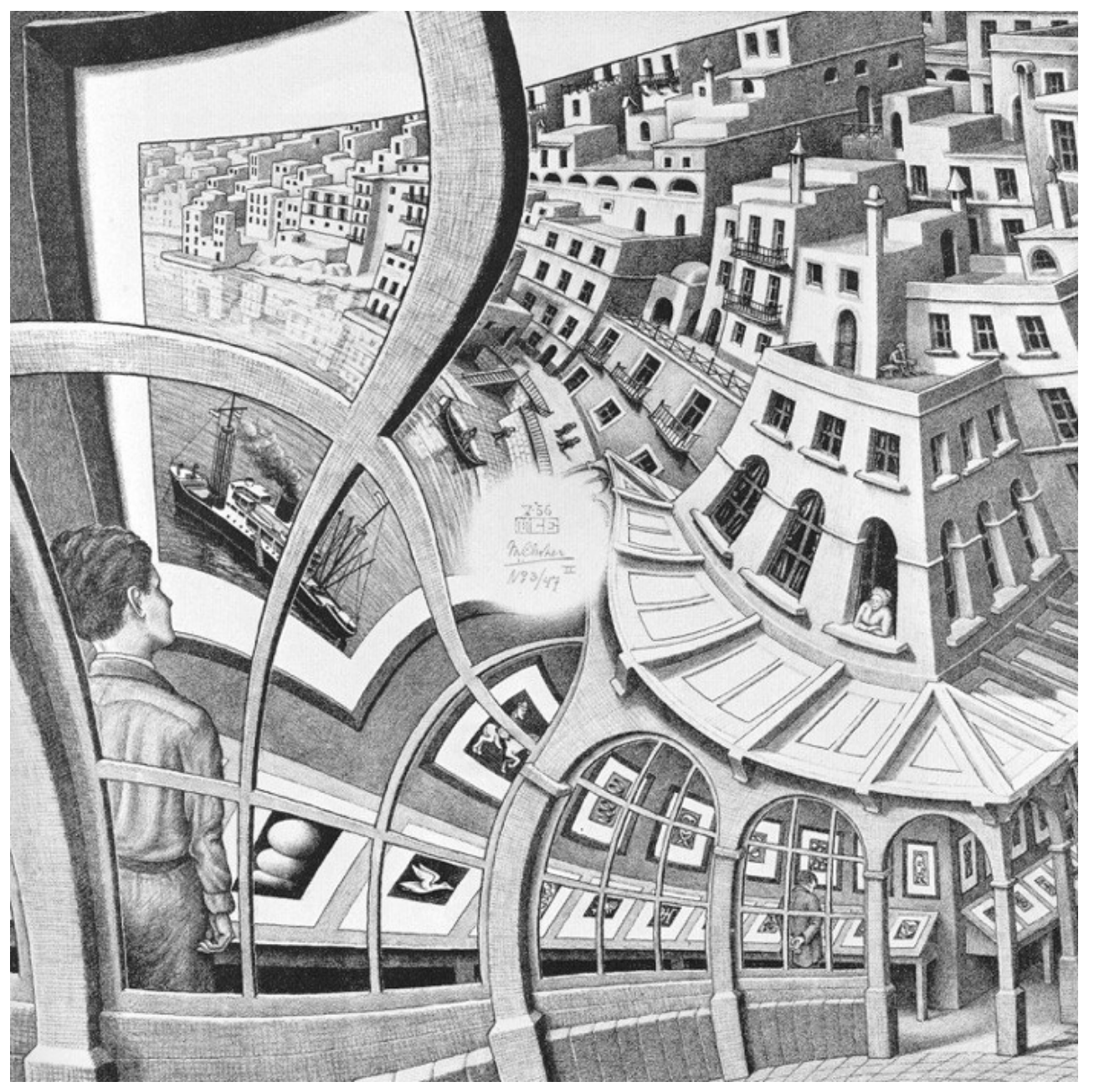

Galeria de Arte, Escher 


\section{Apresentação}

\section{"Lasciate ogne speranza, voi ch'intrate."}

Dante Alighieri, Inferno

Investigar os procedimentos formais adotados por Samuel Beckett em suas cinco primeiras peças teatrais ${ }^{1}$ é escopo deste estudo. A análise formal preserva no objeto de investigação seu viés de derrisão e crítica social, o que foi perdido em uma das agendas analíticas mais populares de sua obra dramática. Divulgada principalmente por Martin Esslin, no livro $\mathbf{O}$ Teatro do Absurdo $^{2}$, esta agenda confere a Beckett o papel de defensor dos pilares fundantes do humanismo ocidental, retirando-o do debate social e político e alçando-o a defensor de verdades transcendentais e transhistóricas. Ao avizinhar a dramática de Beckett, em última instância, da escola existencialista (notadamente a parisiense), Esslin e seus epígonos ignoraram o fato de que o retrato do indivíduo apresentado pelo dramaturgo é aquele que figura o seu ocaso, retirando-Ihe qualquer substancialidade ou condição de sustentar "o que tinham em comum Kierkegaard, Jaspers e a versão sartreana do

\footnotetext{
${ }^{1}$ Não estão incluídos aqui a peça Eleuthéria, escrita contemporaneamente à Godot (que apesar do interesse indiscutível, ainda não compõe integralmente com o teatro posterior de Beckett, estando muito próxima da estética pirandelliana), nem os mimodramas Atos sem Palavras I e II (que dispensam um elemento fundamental do presente estudo, a fala, enquanto narração ou conversação), nem a obra radiofônica (que explora magistralmente e exaustivamente o som sem o suporte da cena, e, por isso, abre um campo de estudo próprio).

${ }^{2}$ Esslin, Martin; O Teatro do Absurdo, Rio de Janeiro: Zahar, 1968.
} 
existencialismo"3. $\mathrm{Na}$ esteira de Adorno, o estudo da forma aqui realizado encontra na obra de Beckett uma 'reflexão' das configurações sociais e do estado paradoxal da arte dentro deste quadro. Como explica Fábio de Souza Andrade: "num mundo privado de sentido imanente, a partir de um sujeito esvaziado da capacidade de reflexão, é preciso elaborar formas significativas, ao mesmo tempo denúncia e cópia deste estado de coisas”"4.

Contudo, se, por um lado, a vertente crítica humanista gerou - ao alijarse do fator histórico - leituras "equivocadamente alegóricas" e metafísicas; por outro lado, produziu estudos que se detiveram pertinentemente no confronto de Beckett com os cânones artísticos tradicionais. Trabalhos seminais como Samuel Beckett: The Comic Gamut de Ruby Cohn, Samuel Beckett: A Critical Study e A Reader's Guide to Samuel Beckett de Hugh Kenner têm o mérito de realçar finamente a mecânica dos textos e apontar sua vocação metalingüística. O presente estudo, ao mesmo tempo em que insere a obra de Beckett em sua época, acatando a abordagem adorniana, preocupa-se igualmente em fundamentar-se numa análise detida das peças em questão, que revele o interesse de Beckett pela forma dramática enquanto problema.

Os dois primeiros capítulos, se têm em comum a identificação das configurações formais das peças analisadas, singularizam-se ao proporcionar conexões extratextuais independentes. Assim, à análise das figuras da

\footnotetext{
${ }^{3}$ Cf. Adorno, T. W; "Intento de entender Fin de Partida" in Notas sobre Literatura, Madrid: Akal, 2003, p.282.

${ }^{4}$ Andrade, Fábio de Souza; Samuel Beckett: O Silêncio Possível, São Paulo, Ateliê, 2001, p.31.

${ }^{5}$ Idem, ibidem, p.29.
} 
circularidade e do confinamento em Esperando Godot, segue-se uma resposta a Peter Szondi, quem concedeu a Beckett um posto assaz modesto no seu 'clássico' Teoria do Drama Moderno. O capítulo dedicado a Fim de Partida, no qual são discutidas as figuras do paradoxo e da inconcludência, empreende uma investigação sobre o lugar da arte num mundo em que "a alienação se completa" ${ }^{\prime}$. O ensaio de Beckett sobre Bran van Velde ${ }^{7}$ e aquele de Adorno sobre Fim de Partida pontuam esta análise. Os três últimos capítulos, que discorrem sobre A Última Fita de Krapp, Dias Felizes e Peça, revisam, nestes textos, as figuras anteriormente analisadas, identificando, no entanto, três figuras novas: a intermitência, a dissimulação e a coatividade. $\mathrm{Na}$ análise das três peças, destaca-se, porém, o interesse de Beckett em promover o público teatral como matéria de investigação (o que já ocorre em certa medida em Esperando Godot e Fim de Partida).

O trabalho conclui com uma justificativa do epíteto 'infernal' para as figuras analisadas, e advoga um adensamento destas figuras em conceitos que possam ser proveitosos para a compreensão tanto da obra desta fase, como da obra beckettiana posterior.

\footnotetext{
${ }^{6}$ Adorno, T. W.; "Intento de entender Fin de Partida" in Notas sobre Literatura, Madrid: Akal, 2003, p.282.

${ }^{7}$ Beckett; Samuel, "Três diálogos com Georges Duthuit", tradução de Fábio de Souza Andrade, in Andrade, Fábio de Souza, opus cit., pp.174-81.
} 


\section{Esperando Godot əo Confinamento e Circularidade əo}

"C'est ça le spetacle, attendre le spetacle"

Samuel Beckett, L'Innommable

"Giramos no mesmo círculo, nunca saímos dele"

Lucrécio, III, 1080 


\section{Introdução}

Vladimir: "Um cão foi à cozinha/ Roubar pão e chouriço/ O chefe e um colherão/ Deram-Ihe fim e sumiço/ Outros cães, tudo assistindo,/ O companheiro enterraram,/ Sob uma cruz que dizia/ Aos demais que ali passavam:/ Um cão foi à cozinha..."

Com esta canção circular, Vladimir inicia o $2^{0}$ ato de Esperando Godot e faz notar alguns elementos formais da peça.

Os infinitos epitáfios insinuados na canção remetem a imagem do girar em falso, em que se retorna sempre ao mesmo ponto, sem fim. E, de fato, em Esperando Godot o público não conta com o alívio de um desfecho. A situação encenada no $1^{\circ}$ ato se repete no $2^{\circ}$, e dá a entender, depois de baixado o pano, que se repetirá. Insinua, inclusive, que é ela mesma repetição ${ }^{9}$. Esta figura, sofrida pelos personagens Estragon e Vladimir em registro espacio-temporal (pois parecem confinados a um mesmo dia e lugar), será discutida na primeira parte deste ensaio.

A canção manifesta ainda outra característica formal da peça: o encaixotamento, representado aqui em duas figuras.

A primeira figura define-se como efeito-matrioshika: a história do cão fala de um epitáfio que contém a história do cão que fala de um epitáfio que contém

\footnotetext{
${ }^{8}$ Beckett, Samuel; Esperando Godot, tradução de Fábio de Souza Andrade, São Paulo: Cosac Naify, 2005, pp. 109-10.

${ }^{9}$ Ao final do $1^{\circ}$ ato, com a primeira entrada do pastorzinho - que traz a notícia de que Godot não virá - Estragon comenta: "Lá vamos nós de novo". Fica sugerido, então, que o pastorzinho já apareceu em outros dias, e com a mesma arenga.
} 
a história do cão que etc. A segunda figura remete à gravura "Galeria de Arte"10 de Escher, em que um "jovem faz parte do mesmo quadro que está a observar"11 . A canção sobre o infortunado cão pode, portanto, ser entendida ao modo das bonequinhas russas, envolvendo-se uma às outras; mas pode também ser entendida como um sistema autocontinente, afinal, a história do cão descreve um epitáfio que descreve a própria história do cão. Estas duas figuras aparecem no segundo momento deste ensaio.

O texto apresenta ainda a análise de um quarto motivo formal, também encontrado na canção: o espelhamento. Aqui os personagens (muitas vezes divididos em duplas) Estragon, Vladimir, Pozzo, Lucky, pastor de cabras, pastor de ovelhas e Godot são abordados a partir dos reflexos com que suas imagens se comunicam.

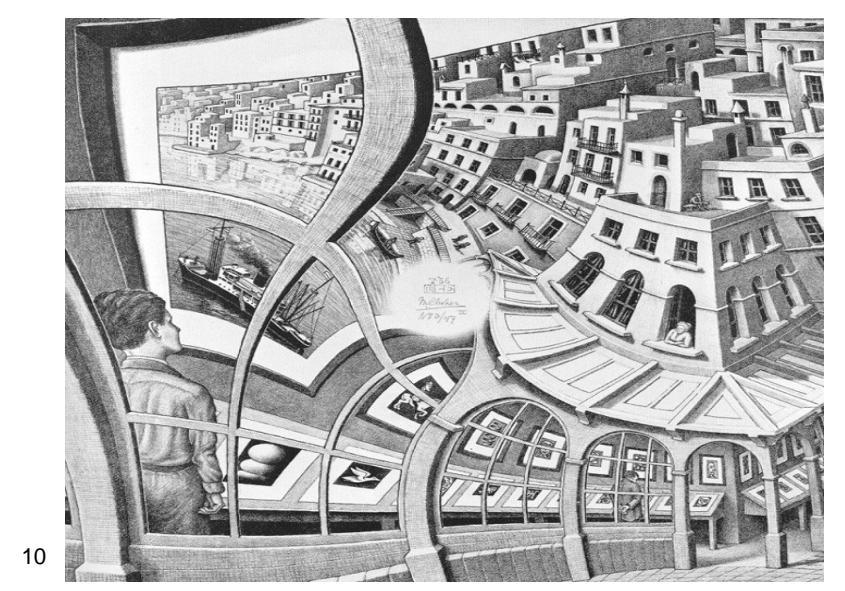

Ernst, Bruno; O Espelho Mágico de Escher, Coréia de Sul: Taschen, 2007.

${ }^{11}$ Idem, ibidem; pp.35-6. 


\section{Paralisados no País da Merda}

Egressos de um mundo que um dia os acolheu, Vladimir e Estragon, encontram-se, no presente que a peça encena, à sua margem. Pois foram respeitáveis em outra época, ao menos o minimamente para poderem ser admitidos entre aqueles que subiam a torre Eiffel, ou para participar das vindimas. Agora encontram-se ao lado de uma árvore, à margem de uma estrada, que, curiosamente, não os conduzirá a parte alguma.

Eis uma introdução possível a Esperando Godot, que, porém, simplifica tanto a sua estrutura temporal - ao conferir-Ihe uma linearidade - como a sua estrutura espacial - ao sugerir diferenças topográficas. Pois Torre Eiffel e vindima são, assim como árvore, marcos possíveis para um fim.

Vladimir: De mãos dadas, pular do alto da torre Eiffel, os primeiros da fila. Éramos gente distinta, naquele tempo. Agora é tarde demais. Não nos deixariam nem subir. ${ }^{12}$

Estragon: Lembra do dia em que me atirei no Reno?

Vladimir: Na colheita das uvas.

Estragon: Você me pescou de volta.

Vladimir: Tudo isso está morto e enterrado. ${ }^{13}$

[Silêncio. Estragon olha atentamente para a árvore]

Vladimir: E o que fazemos agora?

Estragon: Esperamos.

Vladimir: Sei, mas enquanto esperamos?

Estragon: E se a gente se enforcasse ${ }^{14}$

\footnotetext{
${ }^{12}$ Beckett, Samuel; opus cit. p. 19.

${ }^{13}$ Idem, ibidem, p.106.

${ }^{14}$ Idem, ibidem, p.34.
} 
Torre Eiffel, vindima e árvore são, portanto, índices de referência à possibilidade de um desfecho, que, ao serem superpostos - e é isto que a obra parece propor, como lemos abaixo -, diluem o passado no presente cênico, e confundem topografias.

\footnotetext{
Vladimir: ... Não reconhece o lugar?

Estragon: Reconhece? O que há para se reconhecer? Toda a merda da minha vida eu chafurdei na lama! E você fica falando de cenografia! (olha a sua volta) Olhe esse esterco! Eu nunca saí daqui! [...]

Vladimir: Mas você já esteve no País de Gales.

Estragon: Não, eu nunca estive no País de Gales! Eu mijei toda a mijada da minha vida aqui mesmo. Aqui! No País da Merda! $!^{15}$
}

Este espaço-tempo que se encerra em si mesmo, com laivos de eternidade, configura o que Estragon chama de 'País da Merda', perene clausura na espera.

Está enclausurado na espera, aquele a quem um fim ou desfecho é interdito. Não foi possível a Estragon deixar-se afogar no rio durante as colheitas; enquanto clochards, está vedada aos dois personagens a subida à torre Eiffel para um salto espetacular, de mãos dadas; na árvore, não será possível enforcar-se.

\footnotetext{
${ }^{15}$ Beckett, Samuel; Esperando Godot, tradução de Flávio Rangel, São Paulo: Abril, 1976, pp. 111-12. Como se dispõe, em português, de duas ótimas traduções desta obra, citar-se-á ora uma ora outra, quando a tomada de partido do tradutor se afina mais com idéia que se está desenvolvendo neste ensaio. Assim, para facilitar a notação, indicar-se-á com "EG, fsa" a tradução de Fábio de Souza Andrade, e com "EG, fr", a tradução de Flávio Rangel.
} 
Mas esta árvore indica também, na economia da peça, o impedimento para um outro tipo de desfecho diferente do suicídio. Como ficamos sabendo, ela é o ponto de encontro de Vladimir e Estragon com Godot, quem os poderá salvar.

Vladimir: Amanhã nos enforcamos. (Pausa) A não ser que Godot venha.

Estragon: E se vier?

Vladimir: Estaremos salvos! $!^{16}$

Ponto de encontro, no entanto, incerto:

Estragon: [...]Tem certeza que é aqui?

Vladimir: O quê?

Estragon: Que era para esperar.

Vladimir: Ele disse perto da árvore. (Olham a árvore) Você vê outras árvores?

Estragon: Que árvore é essa?

Vladimir: Parece um chorão.

$[\ldots]$

Estragon: Acho que é um arbúsculo.

Vladimir: Um arbusto.

Estragon: Um arbúsculo.

Vladimir: Um... que é que você quer insinuar? Que a gente errou o lugar? ${ }^{17}$

Sem a certeza de estarem no lugar marcado, Vladimir e Estragon protelam a possibilidade deste outro tipo de desfecho, que seria a salvação.

\footnotetext{
${ }^{16}$ EG, fsa, p.194.

${ }^{17}$ EG, fr, pp.19-20.
} 
A soteriologia agostiniana referida por Beckett no $1^{\circ}$ ato ${ }^{18}$, reza que não devemos nem nos desesperar nem presumir diante da promessa da salvação ${ }^{19}$. Afinal, dos dois ladrões, crucificados ao lado de Cristo, um foi salvo e o outro não. O estado de incerteza - nem desespero nem presunção - cria no crente uma suspensão similar àquela em que se encontram Vladimir e Estragon. A espera, suspensão de um desfecho, é aqui, então, não a esperança pela vinda de Godot, mas a incerteza em relação a este acontecimento ${ }^{20}$.

Sem acesso a um futuro redentor, e despojados de passado - ponto de fuga permitido aos nostálgicos personagens tchekovianos -, os dois

18

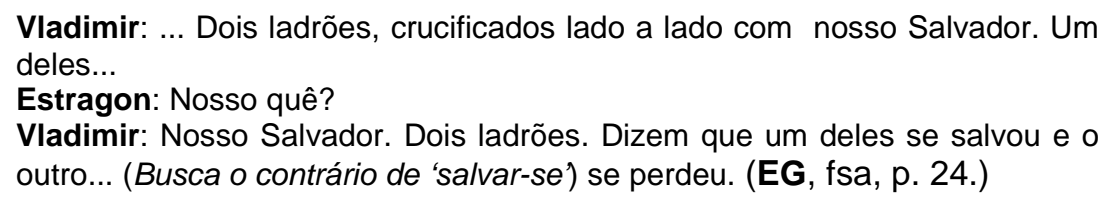

${ }^{19}$ Michael Worton cita a declaração de Beckett feita à Harold Hobson em 1956: "Não tomo partido. Estou interessado na forma [shape] das idéias, mesmo quando não acredito nelas. Há uma frase maravilhosa em Agostinho, queria poder lembrá-la em latim. 'Não desespere, um dos ladrões foi salvo. Não presuma, um dos ladrões foi condenado'. Esta frase tem uma forma maravilhosa. É a forma que importa". Worton, Michael; "Waiting for Godot and Endgame" in The Cambridge Companion to Beckett, Cambridge: Cambridge University Press, 1996, p. 75.)

${ }^{20} \mathrm{O}$ paralelismo sugerido por Beckett entre Vladimir/Estragon/Godot e ladrão-salvo/ladrãocondenado/Jesus não pretende sublinhar o tema da salvação, mas o de sua incerteza. Segundo o comentador francês Bruno Clément, "Encontra-se a mesma oscilação entre o desespero e a confiança no leitor de santo Agostinho como em Vladimir ou Estragon esperando sua salvação ou sua danação com a vinda de Godot. A citação de santo Agostinho, que não é feita, insiste mais sobre a oscilação do que sobre a salvação (...), quer dizer, mais sobre uma forma do que sobre um conteúdo" (Clément, Bruno; L'CEuvre sans Qualités: Rhétorique de Samuel Beckett, Paris: Seuil, 1994, p. 356). A forma, ou seja, a oscilação, manifesta-se semanticamente, pode-se dizer, como incerteza, estando o tema da salvação submisso a este mecanismo instável. 
companheiros encontram-se confinados à eterna presentificação da espera, ao desassossego da espera incerta.

Não é, no entanto, a passividade que preside a sua situação. Ainda que repitam o bordão 'nada a fazer', são inesgotáveis em jogos e conversação:

Estragon: Enquanto esperamos, vamos tratar de conversar com calma, já que calados não conseguimos ficar.

Vladimir: É verdade, somos inesgotáveis. ${ }^{21}$

O que 'não fazem' nem poderiam fazer é atuar ao modo clássico, pois não partilham a liberdade e suficiência dos personagens dramáticos, exercidas no conflito e agraciadas com um desenlace.

Tampouco a inconsciência os domina completamente. Com a entrada de Pozzo e Lucky no $2^{\circ}$ ato, Vladimir discorre sobre a dádiva desta distração, esgotados que pareciam seus esforços para tornar o tempo da espera menos penoso.

Vladimir: Não estamos mais sós, esperando a noite, esperando Godot, esperando - esperando. Lutamos a tarde inteira, com nossos parcos recursos. Agora acabou. Já é amanhã. [...] O tempo voltou a fluir... $^{22}$

E mesmo que ele e Estragon protelem o socorro à outra dupla - que se acidenta tão logo entra em cena -, mesmo que os devaneios de Vladimir retardem o socorro implorado, ele sabe que não deve perder a oportunidade de

\footnotetext{
${ }^{21}$ Idem, ibidem, p. 120.

22 Idem, ibidem, p. 155.
} 
ajudá-la, pois identifica o ato de ajudar a uma diversão, a um desvio de seu enorme tédio.

Vladimir: Estamos esperando. Estamos entediados. (Levanta a mão) Não, não me conteste, estamos tremendamente entediados, é inegável. Bom. Aparece uma diversão e o que nós fazemos? Deixamos apodrecer. Vamos, ao trabalho... ${ }^{23}$

Vladimir e Estragon sofrem e sabem que sofrem a clausura da espera. Ao declarar que a vida inteira se comparou a Cristo, Estragon toma 0 sofrimento como termo da comparação, diante do qual a crucificação parece um alívio.

Vladimir: Mas você não pode andar descalço.

Estragon: Jesus andava.

Vladimir: Jesus! Olha só o que você está dizendo! Não vai querer se comparar a ele?

Estragon: A vida toda me comparei.

Vladimir: Mas por lá fazia calor! Não chovia!

Estragon: É. E crucificavam rápido. ${ }^{24}$

E de fato é ele quem a todo instante tem - ainda que sempre malogrados ${ }^{25}$ - 0 rompante de partir e o desejo de matar-se. É ele ainda que pressente sua relação com Godot como aprisionamento ${ }^{26}$ :

${ }^{23}$ Idem, ibidem, p. 162.

${ }^{24}$ Idem, ibidem, pp. 104-5.

${ }^{25}$ São inúmeras as passagens em que Estragon propõe que partam, mas sempre tem o intento malogrado ao ser lembrado por Vladimir de que precisam esperar Godot. É também Estragon quem sempre quer dormir (e dorme), para evitar o tempo da espera.

Estragon: Vamos Embora.

Vladimir: A gente não pode.

Estragon: Por quê?

Vladimir: Estamos esperando Godot.

Estragon: É mesmo.

Idem ibidem, pp. 93-4.

${ }^{26}$ Para ressaltar a idéia de aprisionamento, Beckett sugeriu, nas montagens do SchillerTheater e de San Quentin, que os movimentos de Vladimir lembrassem aqueles de alguém em uma cela, e aventou, inclusive, a possibilidade de serem projetadas no palco, durante a 
Estragon: (...) Perguntei se estamos amarrados.

Vladimir: Amarrados?

Estragon: A-mar-ra-dos.

Vladimir: Amarrados, como?

Estragon: Pés e mãos.

Vladimir: Mas a quem? Por quem?

Estragon: Ao seu homem.

Vladimir: A Godot? Amarrados a Godot? Que idéia! De maneira nenhuma! (Pausa) Não... ainda. ${ }^{27}$

\section{O Círculo dos Sonâmbulos}

Contudo, o exemplo mais contundente de lucidez, vem de Vladimir que, no $2^{0}$ ato, toma posse de sua condição. Este lampejo, ainda que efêmero, luzindo no corpo de poucas frases logo esquecidas, revela a chave temáticoformal da obra, e lança o espectador num redemoinho de referências culturais alentado pelas filosofias cética e gnóstica, pelas Meditações de Descartes, pela ontologia de Berkeley e pela comédia A Vida é Sonho.

Ao final do $2^{\circ}$ ato, depois da saída de Pozzo e Lucky, Estragon, sem paciência para as digressões de Vladimir a respeito da cegueira de Pozzo, sugere ao amigo que:

encenação, a sombra de barras. Beckett pediu ainda, para estas montagens, que os dois personagens estivessem juntos em cena já no início dos dois atos, reforçando a idéia de sua inseparabilidade. Cf. Knowlson, James e Mcmillan, Douglas; The Theatrical Notebooks of Samuel Beckett - Waiting for Godot, New York, Groove Press, 1994 p. xxii-xxiii. Os dois personagens encontram-se, portanto, amarrados a Godot (ou ao menos à sua espera) e amarrados um ao outro (assim, como Lucky está literalmente amarrado a Pozzo, quem o conduz por uma corda).

${ }^{27}$ Idem, ibidem, p. 44. 
Estragon: Você sonhou tudo isso ${ }^{28}$.

Vladimir, no entanto, como é seu costume, estende o sentido de um comentário prosaico a seus possíveis significados metafísicos ${ }^{29}$.

\begin{abstract}
Vladimir: Eu estava dormindo, enquanto os outros sofriam? Estarei dormindo agora? Amanhã, quando eu estiver pensando que acordei, que direi do dia de hoje? Que junto com Estragon, meu amigo, neste lugar, até o cair da noite, eu esperei por Godot? Que Pozzo passou com seu escravo e falou conosco? Sem dúvida. Mas o que haverá de verdade em tudo isso $?^{30}$
\end{abstract}

Desde os antigos, o ceticismo problematizou, por meio de argumentos (ou tropos), a possibilidade de poder-se ter das coisas um conhecimento seguro ou verdadeiro. $\mathrm{O}$ argumento do sonho postula a eqüipolência das

${ }^{28}$ EG, fr, p. 177. Note-se que outras são as vezes em que Estragon acusa Vladimir de estar ou ter sonhado suas lembranças:

Vladimir: A árvore, preste atenção na árvore.

Estragon olha para a árvore.

Estragon: Não estava aí ontem?

Vladimir: Claro que estava. Esqueceu? Estivemos a ponto de nos enforcarmos nela. (...) Não está lembrado?

E ainda: Estragon: Você sonhou.

Estragon: Estou dizendo que não estávamos aqui ontem à tarde. Você teve um pesadelo.

Idem Ibidem, p. 116 e 130.

${ }^{29}$ A primeira frase da peça é emblemática: 'nada a fazer'. Estragon diz a frase referindo-se ao sapato que não consegue tirar do pé. Mas Vladimir a entende de outro modo, fazendo-a deslizar semanticamente da dificuldade com o sapato para a impotência do homem em mudar (sua vida, ou a vida). Segundo Jean-Pierre Ryngaert, o cruzamento destes dois sentidos de 'nada a fazer' estabelecem "de entrada o registro do texto, confrontando o banal e o pomposo, o extremamente prosaico com a declaração demasiadamente grave para ser também honesta". (Ryngaert, Jean-Pierre; Lire en Attendant Godot de Beckett, Paris Dunod, 1993, p. 49.)

${ }^{30}$ EG, fr, p. 178. 
impressões advindas do sonho e da vigília ${ }^{31}$, e sugere, assim, a impossibilidade de decidir-se por uma ou por outra.

Descartes atualiza este argumento nas Meditações. "Quantas vezes confessa - ocorreu-me sonhar durante a noite, que estava neste lugar, que estava vestido, que estava junto ao fogo, embora estivesse inteiramente nu dentro do meu leito? Parece-me agora que não é com olhos adormecidos que contemplo este papel; que esta cabeça que mexo não está dormente; que é com desígnio e propósito deliberado que estendo esta mão e que a sinto: o que ocorre no sono não parece ser tão claro nem tão distinto quanto tudo isso. Mas, pensando cuidadosamente nisso, lembro-me de ter sido muitas vezes enganado, quando dormia, por semelhantes ilusões. E, detendo-me neste pensamento, vejo tão manifestamente que não há quaisquer indícios concludentes, nem marcas assaz certas por onde se possa distinguir nitidamente a vigília do sono, que me sinto inteiramente pasmado: e meu pasmo é tal que é quase capaz de me persuadir de que estou dormindo"32.

A dúvida natural - que se apóia no argumento do sonho para recusar o fundamento sensível do conhecimento -, juntamente com a dúvida metafísica que postula a existência de um deus enganador para recusar a matemática como fundamento do conhecimento -, pertencem a uma etapa do método

\footnotetext{
31 "Estar dormindo e estar acordado [...] gera diferentes impressões, pois não imaginamos quando acordados, aquilo que imaginamos durante o sono, nem quando adormecidos imaginamos o mesmo que acordados; portanto, a existência ou não-existência de nossas impressões não é absoluta, mas relativa ao nosso estado de sono ou vigília". (Sextus Empiricus; Outlines of Pyrrhonism, London: Harvard University Press, 1993, p. 139)

32 Descartes, R.; Meditações in Obra Escolhida, tradução de J. Guinsburg e Bento Prado Júnior, São Paulo: Difel, 1973, p. 119.
} 
cartesiano. Ao colocar em xeque todas as representações, de modo radical e hiperbólico, o filósofo está à procura de uma certeza que não seja passível de dúvida, um ponto fixo a partir do qual possa reconstruir todo o saber. Este ponto fixo será, como se sabe, o cogito, o pensamento. Portanto, o ceticismo de Descartes é instrumental e provisório ${ }^{33}$.

O ceticismo antigo, por sua vez, não pretende duvidar da existência do mundo, mas suspender o juízo sobre as opiniões e crenças a ele relativas, pois constata, por investigação constante, a impossibilidade de encontrar-se nelas a verdade. Suspendendo o juízo, o cético alcançaria a ataraxia, uma serena impassibilidade diante de quadro tão instável.

Contudo, o assombro com que Vladimir questiona a verdade de suas vivências recentes, o assombro com que considera a possibilidade de estar de fato dormindo, extrapola o caráter epistemológico, moral e provisório com que o argumento do sonho se reveste nos exemplos precedentes e sugere o caráter onírico da própria existência. Poderiam ser suas as palavras com que Segismundo, personagem de A Vida é Sonho, declara a vida como ilusão: "Que é a vida? Um frenesí. Que é a vida? Uma ilusão, uma sombra, uma ficção; o maior bem é tristonho, porque toda a vida é sonho e os sonhos, sonho são"34.

${ }^{33}$ Cf. Leopoldo e Silva, Franklin; Descartes - a metafísica da modernidade, São Paulo: Moderna, 2005., pp. 26-41.

${ }^{34}$ Calderón de La Barca, Pedro; A Vida é Sonho, traduzido por Renata Pallottini, São Paulo: Página Aberta, 1992. 
Mas não é apenas a sensação onírica da existência que aproxima Esperando Godot de A Vida é sonho, aproxima-as também o fato de nas duas peças serem mantidos deliberadamente em inconsciência os personagens. Num caso, Segismundo, preso numa torre, é vigiado por Clotaldo, que sabe de sua ascendência nobre, mas não lhe revela; no outro, Vladimir considera-se observado por alguém que reconhece a precariedade de sua consciência, mas o abandona simplesmente à própria ignorância. Diz Vladimir, na seqüência de seu devaneio sobre estar ou não dormindo:

\begin{abstract}
Vladimir: (Estragon, que tentara em vão tirar os seus sapatos, cochilou de novo. Vladimir o contempla.) [...] Também para mim alguém está olhando, também sobre mim alguém estará dizendo: Ele está dormindo, ele não sabe de nada, deixe-o dormir ${ }^{35}$.
\end{abstract}

Em Esperando Godot, exercitam-se vários modos de articulação do par observado-observador, dos quais vale destacar dois ${ }^{36}:$ 1) o personagem ignora que está sendo observado; 2) o personagem necessita do testemunho de um outro. É exemplar, neste último caso, a primeira entrada de Pozzo, que instaura abertamente o teatro dentro do teatro:

Vladimir: Ele vai falar.

Imóveis, um apoiado no outro, [Estragon e Vladimir] esperam.

Pozzo: ... Todos a postos? Todos olhando pra mim? (Olha para Lucky, puxa a corda, Lucky levanta a cabeça) Olhe para mim, porco! (Lucky olha) Ótimo. (Coloca o cachimbo no bolso, retira um pequeno

\footnotetext{
${ }^{35}$ EG, fr, p. 178.

${ }^{36}$ Uma outra ocorrência seria aquela em que os personagens necessitam do outro como distração, divertimento. Estragon e Vladimir, por exemplo, distraem-se de sua espera com as duas entradas de Pozzo e Lucky.
} 
vaporizador, vaporiza a garganta...) Estou pronto. Estão todos me escutando? $[\ldots]^{37}$

Também Vladimir necessita de testemunha. Ao final dos dois atos, insiste ao menino - pastor dos rebanhos de Godot - que este avise seu senhor de tê-los visto:

Menino: O que eu digo ao senhor Godot, Senhor?

Vladimir: Diga... (hesita) diga que nos viu. (Pausa) Você viu mesmo, não viu?

Menino: Sim, senhor. (Recua, hesita, vira-se e sai correndo) ${ }^{38}$

O princípio berkeleyano "esse est percipi" (ser é ser percebido ${ }^{39}$ ) parece mover Pozzo e assombrar Vladimir nestes dois casos. Eles sofrem o mesmo terror de Mr. Knot, personagem do romance Watt, que necessita de empregados como testemunhas 'perceptivas' de sua existência. O terror de não-ser ao não ser percebido parece, no entanto, menos sinistro do que estar inconsciente sob o olhar (e do olhar) de um outro. No $2^{0}$ ato, após a partida de Pozzo, agora cego, Vladimir tem a impressão incômoda de ter sido observado:

\footnotetext{
${ }^{37} \mathrm{EG}$, fsa, p. 61.

${ }^{38}$ Idem, ibidem, p. 103.

39 "O que se tem dito da existência absoluta de coisas impensáveis sem alguma relação com o seu ser-percebidas parece perfeitamente ininteligível. O seu esse é percipe [o seu ser é serem percebidas]; nem é possível terem existência fora dos espíritos ou coisas pensantes que os percebem". (Berkeley, George; Dos Princípios do Conhecimento Humano, I, 3, in
} Pensadores: Berkeley, Hume, São Paulo: Abril, 1984.) Estragon, no entanto, não vincula o ser (existir) ao ser percebido, mas ao inventar maneiras de distrair-se:

Estragon: Até que a gente se vira, não é, Didi, os dois juntos? [...] Estamos sempre achando alguma coisa, não é, Didi, para dar a impressão de que existimos?

(EG, fsa, p. 138.) 
Vladimir: Fiquei com a impressão de que [Pozzo] estava nos vendo. $^{40}$

$\mathrm{E}$, ao início dos $1^{\circ}$ e $2^{\circ}$ atos - de acordo com a versão revisada da peça feita por Beckett para as produções do Schiller-Theater e de San Quentin - deparase com os seguintes quadros: num caso, Vladimir, meio à sombra, em silêncio, presta atenção em Estragon sentado no chão; no outro, Estragon, à sombra, observa Vladimir cantar, sem que este o veja ${ }^{41}$.

Ser sob o olhar de um outro é estar subtraído de uma verdade, de um sentido a respeito de si mesmo. Tem-no apenas aquele que 'percebe'. Quem, então, percebe-observa Vladimir, do mesmo modo que ele observa Estragon?

Em Berkeley, é a mente de Deus, sujeito cognoscente absoluto, que percebe todas as coisas, garantindo a existência do mundo. Será, então, Deus aquele que percebe-observa Vladimir observar Estragon dormir? Ou se pode conjecturar - por livre associação - que aquele que olha Vladimir, não é o Deus 'perceptor' de Berkeley, mas o deus enganador de Descartes, entorpecendoIhe o entendimento? Ou será Godot, esta caricatura de deus - conjugando em seu nome a palavra God (deus) mais a partícula diminutiva 'ot' (do francês) será Godot, incompetente até para honrar um simples encontro, o deus que abandona Vladimir em sua inconsciência? Ou talvez ainda - dando livre curso a imaginação -, não se poderia supor que aquele que olha para Vladimir seja o demiurgo gnóstico, deus mau, que, desconhecendo a própria origem e natureza, mantém na ignorância e na dor os homens, suas criaturas? Afinal,

\footnotetext{
${ }^{40}$ Idem ibidem, p. 185.

${ }^{41}$ Cf. Knowlson, J., McMillan, D.; opus cit., p. xiii.
} 
como diz Vladimir, atestando, ao que parece, a condição existencial perversa do homem:

Vladimir: [...] Com um pé na cova e um nascimento difícil. Do fundo do buraco, indolentemente, o Coveiro aplica seu fórceps. Temos tempo de envelhecer. $\mathrm{O}$ ar está cheio de nossos gritos. (Escuta) Mas o hábito é uma grande surdina. ${ }^{42}$

Ora, mas se estas digressões são possíveis - e muitos foram os comentadores que defenderam uma leitura teônoma da obra - elas são sustentadas, no entanto, por pensamentos clandestinos, enxertados num texto que oferece uma definição própria de Deus. Diz Lucky logo no início de seu longo monólogo:

\footnotetext{
Lucky: (exposição monótona) Dada a existência tal como se depreende dos recentes trabalhos públicos de Poinçon e Wattmann de um Deus pessoal quaquaquaqua de barba branca quaqua fora do tempo e do espaço que do alto de sua divina apatia sua divina athambia sua divina afasia nos ama a todos com algumas exceções não se sabe por quê mas o tempo dirá... ${ }^{43}$
}

Deus, portanto, é descrito no texto como um ser apático (insensível), 'athâmbico' (ou seja, indiferente) e afásico (impotente para falar, para comunicar-se $)^{44}$. Um Deus como este não se importaria com o estado de consciência de Vladimir, velando-o e interpretando-o ('ele não sabe de nada'),

\footnotetext{
${ }^{42} E G$, fr, p. 178.

${ }^{43}$ EG, fsa, p.85.

${ }^{44}$ E se há, pelo menos na versão em inglês da obra, referência explícita ao Bispo Berkeley, esta é feita em tom satirizante, por Lucky, em seu monólogo. "... I resume Fulham Clapham in a word the dead loss per caput sinde the death of Beishop Berkeley being to the tune of one inch four ouce per caput approximately..." (Samuel, Beckett; The Complete Dramatic Works, London: Farber and Farber, 1990, p. 43.)
} 
nem demonstraria por ele esta compaixão cansada, revelada na frase: 'deixe-o dormir'.

Se não for Deus aquele que vigia Vladimir, deve-se aventar, portanto, outra hipótese que respeite os dados oferecidos pelo texto, bem como seu estatuto teatral.

Em Esperando Godot, os personagens, repetidas vezes, enunciam (e denunciam, ainda que inconscientemente) seu caráter ficcional e o jogo teatral a que estão submetidos. À quase recusa e dificuldade de Estragon em encetar uma conversa (um diálogo mitigado), Vladimir reclama com jargão do métier.

Vladimir: [...] Puxa, Gogo, devolve a bola de vez em quando. ${ }^{45}$

Estragon, para apaziguar Vladimir, que se mostra aturdido pelo fato de ter despertado inutilmente todo um ossário, declara que o contratempo não foi em vão, ao menos serviu como 'aquecimento'46. E ao tentar sair de cena e fugir da alarmante vacuidade de seu dia, Estragon bate na parede de fundo do palco, retorna de uma tentativa de evasão pelas coxias, e, apavorado, recua do fosso da orquestra, pontuando os limites de seu território. E como isso não bastasse, Vladimir reforça ainda mais a idéia de estarem sobre um palco, dizendo:

\footnotetext{
${ }^{45}$ EG, fr, p. 16 .

${ }^{46}$ Em francês: "Estragon: Ce n'est pas si mal comme petit galop." (Beckett, Samuel; En Attendant Godot, Paris: Minuit, 1990, p. 91.). Em inglês: "Estragon: That wasn't such a bad little canter." (Beckett, Samuel; The Complete Dramtic Works, London: Farber and Farber, 1990, p. 61.
} 
Vladimir: De fato, estamos num platô. Não há dúvida, servidos num platô. $^{47}$

Em francês, platô (plateau) carrega mais sentidos do que em português. Plateau, além de uma espécie de planalto, é também bandeja, prato, e, o que interessa, o próprio palco ${ }^{48}$. Os personagens são, portanto, peças movidas num jogo dramático, cuja sensação existencial onírica coincide com sua condição ficcional. Como dizia Segismundo: ‘Que é a vida? Uma ilusão, um sonho, uma ficção'.

Isso posto, não seria sem propósito presumir que aquele que observa silenciosamente a condição existencial-ficcional de Vladimir é, nada mais nada menos, que o público na platéia.

Se assim for, o público participa também deste círculo de sonâmbulos. 0 sono de Estragon é percebido por Vladimir, e a condição onírico-ficcional dos dois amigos é percebida pelo público, que é, por sua vez, 'percebido' (assimilado) pela própria peça.

Mas, se a peça sonha a todos (público, Vladimir e Estragon), é o hábito, pode-se dizer, que os mantém dormindo. Vladimir entende o mecanismo habitual perfeitamente:

Vladimir: ...Com um pé na cova e um nascimento difícil. Do fundo do buraco, indolentemente, o Coveiro aplica seu fórceps. Temos tempo

\footnotetext{
${ }^{47}$ EG, fsa, p. 148.

${ }^{48}$ Cf. Knowlson, J., McMillan, D.; opus cit., p. xv.
} 
de envelhecer, o ar está cheio de nossos gritos. (Pausa) Mas o hábito é uma grande surdina. ${ }^{49}$

Vladimir ressente, aqui, a indolência do coveiro a dilatar o tempo, que, como foi dito, é o tempo angustiante de uma espera incerta. Espera, lembre-se, sofrida com intensidade igual por personagens e platéia. O que se enfatiza nesta fala, não é o mistério do não-Ser nas pontas de uma existência, mas o sofrimento da espera. O foco está nos gritos emitidos durante o lento percurso entre estes dois 'buracos': o útero e a cova. No entanto, 'o hábito é uma grande surdina'. Por força do hábito, Estragon prosseguirá com suas tarefas comezinhas.

Vladimir: ... Ele [Estragon] não saberá de nada. Ele falará dos golpes que recebeu e eu Ihe darei uma cenoura... ${ }^{50}$

E o próprio Vladimir será 'dormido' pelo hábito ao final de seu lampejo de lucidez, tornando-o inócuo.

Vladimir: ... (Olha Estragon) Também para mim alguém está
olhando, também sobre mim alguém estará dizendo: Ele está
dormindo, ele não sabe de nada, deixe-o dormir. (Pausa) Não posso
mais continuar. (Pausa) O que foi que eu disse? ${ }^{51}$

No momento em que pressente a presença do público ("também para mim alguém está olhando"), e implicitamente tem revelada sua condição existencial como condição ficcional, é neste momento de lucidez que Vladimir se desespera ("não posso mais continuar"). Lucidez fugaz, porém, rapidamente esquecida (“o que foi que eu disse?"). O hábito-surdina abafa gritos e apaga

\footnotetext{
${ }^{49}$ EG, fr, p. 178.

${ }^{50}$ Idem, ibidem, p. 178.

${ }^{51}$ Idem, ibidem, p. 178.
} 
clarividências. Vladimir renovará com o menino-pastor o compromisso de esperar mais um dia por Godot. E mesmo o público, por hábito, também esperará por um desfecho e um sentido, tentando manter com esforço sua costumeira passividade, sem entender que foi tragado para dentro deste círculo de sonâmbulos.

Assim como as bonequinhas russas, que contém uma às outras, em Esperando Godot os personagens estão contidos um no olhar do outro (Estragon, no olhar de Vladimir, e ambos no olhar de um público, assimilado à peça). Assim como na gravura 'Galeria de Arte' de Escher, em que um rapaz está contido no quadro que observa, aqui o público está contido na peça que assiste. As figuras de encaixotamento, expostas deste modo, conferem ao conceito de hábito um outro efeito além daquele de surdina. O hábito tem revelado também seu efeito de prisão ou aprisionamento. É o hábito que aferra Vladimir e Estragon a Godot, é o hábito que os aferra um ao outro. A peça desenvolve o tema da espera enquanto hábito na forma de um confinamento espacio-temporal (personagens limitados ao palco, e à eterna repetição). 


\section{Um Espelho Imperfeito ${ }^{52}$}

Vladimir, Estragon, Pozzo, Lucky, assim como, de modo mais discreto, pastorzinho de cabras, pastorzinho de ovelhas e Godot, revelam traços comuns que se refletem uns nos outros, mas ao modo de um espelhamento imperfeito ${ }^{53}$. Pode-se dizer que os personagens fazem eco uns aos outros em reverberações que se distorcem, mas persistem de algum modo. Sem pretender esgotar todos os reflexos, seguem-se alguns:

- A violência física é traço de todos os personagens. Estragon confessa, ao início dos dois atos, ter sido espancado; por relato, fica-se sabendo que Godot surra o pastorzinho de ovelhas; Lucky chuta Estragon, que depois tem a oportunidade de revidar; Vladimir bate em Pozzo.

\footnotetext{
${ }^{52}$ Pode-se pensar na relação especular entre esta peça e outras obras de Beckett, como, por exemplo, uma que lhe é muito próxima, o romance Mercier et Camier. A relação especular entre a peça e o que se pode chamar 'mundo ativo' também não deve ser negligenciada. A ação que inscreve o homem no mundo contemporâneo não corresponde pacificamente à ação dramática clássica. Diversos fatores históricos tornam problemático este acordo. Segundo Günther Anders, em seu ensaio "Être sans temps", a atividade torna-se hoje uma variante da passividade, na medida em que os milhões de homens ativos, sujeitos ao trabalho mecânico, não compreendem o que fazem, ou qual o objetivo de suas funções. Ao subverter a ação dramática em pseudo-ações falhadas, Beckett, de acordo com Anders, apontaria a congruência destas ações - que querem fingir-se ações -, com a atividade das massas, que, em verdade, não têm efeito real sobre o mundo. Vladimir e Estragon, em sua inatividade, representariam milhões de homens ditos ativos. O público espelhado assim no palco, encararia seu traço absurdo: continuar otimista e obstinadamente, a despeito da esterilidade dessa persistência. (Anders, Günther; "Être sans temps - à propos de la pièce de Beckett En Attendant Godot" in L'Obsolescence de L'Homme - Sur l'Âme à l'Époque de la Deuxième Révolution Industrielle, Paris: Éditions de L'Encyclopédie des Nuisance, Édition Ivrea, 2002)

${ }^{53}$ Como lembra Kristin Morrison, Beckett em suas anotações para a montagem de Godot em Berlim (1975) usou largamente as palavras 'espelho', 'eco' e 'paralelo'. (Morrison, Kristin;
} Canters and Chronicles - the use of narrative in the plays of Samuel Beckett and Harold Pinter, Chicago, London: The University of Chicago Press, 1986, p.53) 
- Dormir 'no seco, sobre a palha', na casa de Godot, é anelo de Vladimir e Estragon, e é realidade para os pastorzinhos, que dormem 'sobre a palha' no celeiro de Godot.

- Vladimir e Estragon esperam ser 'salvos' por Godot; Vladimir se refere também aos dois ladrões crucificados ao lado de Cristo, dos quais apenas um foi salvo; Pozzo pretende vender Lucky no mercado de 'São Salvador ${ }^{54}$.

- Pozzo, que se diz dono de terras e proprietário de uma mansão, reflete de algum modo a imagem que se faz de Godot, também proprietário de casa, terras e rebanhos.

- Súplicas por piedade são emitidas por Estragon a Deus; por Pozzo a Estragon e Vladimir; e o papel dos dois amigos em relação a Godot é o de 'suplicantes'.

- Enquanto Estragon se sente 'amarrado' a Godot, Lucky está literalmente amarrado a Pozzo, por uma corda que the cinge o pescoço.

- Vladimir, Estragon, Pozzo e Lucky usam chapéu côco.

- O bordão 'nada a fazer' pontua toda a permanência de Estragon e Vladimir em cena e faz ressaltar a esterilidade de suas pequenas e intermináveis ações. A esterilidade de toda ação é enfatizada também por Pozzo, em chave conformista, quando diz que "as lágrimas do mundo são em quantidade constante. Para cada um que irrompe em choro, em outra parte alguém pára. Com o riso é a mesma coisa. (...) Não falemos mal, então, dos nossos dias, não são melhores nem piores do que os que vieram antes. (...) Não falemos bem, tampouco. (...) Não

\footnotetext{
${ }^{54} \mathrm{Na}$ versão em inglês, não é mencionado o nome do mercado.
} 
falemos" ${ }^{\prime \prime 5}$. De um modo e de outro, os personagens revelam-se inapropriados ao jogo dramático: resignando-se a não atuar (não fazer nada) e a não falar (não externar conceitos e defendê-los).

- Usar o outro como divertimento é comum às duas duplas. Vestir as botas pode ser um bom divertimento, garante Vladimir a Estragon, pois "ajuda a passar o tempo". O outro é sempre objetificado, e, assim como um par de botas, torna-se instrumento para di-vertir do tempo angustiante da espera. À saída de Pozzo e Lucky no $1^{\circ}$ ato, Vladimir comenta que o encontro com eles 'ajudou a passar o tempo'. No $2^{\circ}$ ato, a chegada da mesma dupla é comemorada por Vladimir como uma diversão - "Estamos entediados. (...) Aparece uma diversão e o que nós fazemos? (...) Vamos ao trabalho"56 -, diversão que contribui para que 0 tempo 'volte a fluir'. Note-se, no entanto, que este mote da filosofia pascaliana, o divertimento, comparece aqui com os sinais trocados. $O$ divertimento, segundo Pascal, é buscado pelos homens para fugirem da consciência de sua condição existencial miserável. Em Esperando Godot, porém, a diversão manifesta sua própria precariedade, criando mais angústia e revelando de modo enfático aquilo que quer disfarçar. Para Pozzo também o divertimento é relevante. Mas tem valor monetário, como acumulação e troca. No primeiro caso, Pozzo considera possível capitalizar todos os imprevistos que pontuam o seu percurso. Como diz: "Até da mais humilde das criaturas nós nos despedimos mais sábios, mais ricos, mais seguros de nossas bençãos. Até vocês... [Estragon e Vladimir] (...) até vocês, quem sabe, me

\footnotetext{
${ }^{55}$ EG, fsa, p. 65.
}

${ }^{56}$ Idem, ibidem, p. 162. 
acrescentarão alguma coisa" ${ }^{\text {"57 }}$. No segundo caso, Pozzo oferece para Vladimir e Estragon uma performance de Lucky, seu ex-bufão, como pagamento à 'correta' reação da dupla diante de sua piegas descrição do ocaso. Lucky, então, é forçado a exibir-se, dançando e, depois, pensando.

- $\underline{O}$ ato de pensar é problema para as duas duplas. Lucky performa o ato de pensar, parodiando o modus acadêmico, numa digressão tripartite ${ }^{58}$ que, iniciada com a constatação da indiferença divina, excursiona pelo apequenamento do homem (que ocorre a despeito do progresso das ciências), e se encerra com uma assemblage de imagens (crânios ${ }^{59}$, pedras, escuridão e gelo) que associa o nosso planeta a um enorme túmulo ${ }^{60}$. O pensamento de Lucky, à medida que se desenvolve, causa em seus ouvintes desconforto, inquietação, mostrando-se, finalmente, insuportável, e levando-os a encerrá-lo à força. A última palavra pronunciada por Lucky, no entanto, 'inacabados', remete não só aos trabalhos acadêmicos citados, ou a seu próprio pensamento inconcluso,

\footnotetext{
${ }^{57}$ Idem, ibidem, p. 59.

${ }^{58}$ Beckett, nas anotações para a montagem do Schiller Theater, dividiu em três partes a estrutura temática do pensamento de Lucky: céu indiferente, homem diminuente e terra como morada de pedras. Cf. Knowlson, opus cit., p.132.

${ }^{59} \mathrm{Em}$ francês, tête; em inglês, skull. Vale lembrar que 'skull' remete o leitor à paixão de Cristo, ocorrida no Gólgota, lugar da caveira (segundo Marcos, 15:22).

${ }^{60} \mathrm{Na}$ versão francesa, a idéia de túmulo é reforçada pela menção à Normandia. Esta região, como se sabe, foi palco da devastadora invasão aliada, no chamado dia-D. Além disso, na pequena vila normanda de Saint-Lô (que o autor chamou de Capital das Ruínas), Beckett serviu junto à cruz vermelha. (Cf. Knowlson, James; Damned to Fame, London: Bloomsbury, 1997, pp. 345-51) É curioso que nas versões para o inglês e para o alemão (esta supervisionada por Beckett), substitui-se o nome da região por outros - Connemara, Oldenburg - que mantêm em comum com a Normandia apenas seu caráter geológico: as formações rochosas.
} 
mas, de um modo mais geral, à inconcludência da peça e do destino de seus personagens. Para Vladimir e Estragon, por sua vez, $\underline{0 \text { ato de }}$ pensar desperta vozes mortas, ressuscita cadáveres, faz aflorar ossadas, engendra todo um cemitério ${ }^{61}$. O pensamento é ressurrector e impede que o passado simplesmente passe. Nos dois casos, o ato de pensar aparece associado à morte, mais precisamente à impossibilidade da morte: em nível cosmológico, o planeta, apesar (ou em razão) de todos os progressos humanos, é um túmulo inacabado; no nível pessoal, o passado assombra o presente, orbitando ${ }^{62}$ (mas nunca integrando) a unidade apaziguadora de um sujeito.

- Todos os personagens padecem de lapso de memória ${ }^{63}$. No $1^{\circ}$ ato, Vladimir não se lembra de já ter estado 'ontem' - como Ihe comunica Estragon - no local onde se encontram ${ }^{64}$. No $2^{\circ}$ ato é Estragon quem não reconhece o lugar, e recusa a aceitar que os fragmentos de lembranças que tem do $1^{\circ}$ ato $^{65}$ aconteceram 'ontem'. Pozzo, no $1^{\circ}$ ato,

\footnotetext{
${ }^{61}$ EG, fsa, pp. 120-6.

${ }^{62}$ Segundo Bruno Clément, "como Vladimir e Estragon, personagens sem peça que procuram uma intriga, um lugar, um tempo, [assim também] as vozes mortas, memoria sem memória, erram como fantasmas à procura de um crânio ondem possam, não reencarnar, mas prosseguir, perseverar em sua conversação eterna". (Clément, Bruno; opus cit. p. 378). A mala repleta de areia, empunhada por Lucky nos dois atos, poderia ser compreendida, neste sentido, como insígnia do pensamento estéril (ou esterilizado). Carregar a mala repleta de areia é também ação absurda. Neste caso, portar a mala estaria para Pozzo e Lucky, como o hábito (ação irracional) está para Vladimir e Estragon, ao comparecerem dia após dia a um encontro impossível.

63 "As perdas de memória se justificariam em parte pela acumulação dos dias sempre semelhantes dos quais veremos apenas dois..." (Ryngaert, J-P.; Lire en Attendant Godot de Beckett, Paris: Dunod, 1993, p. 79.)

${ }^{64}$ EG, fsa, pp. 29-30.

${ }^{65}$ Idem, ibidem, pp. 116-117.
} 
não reconhece (ou ao menos parece não reconhecer) Vladimir e Estragon, a despeito de - como relata Vladimir - já haverem se encontrado antes ${ }^{66}$. E no $2^{\circ}$ ato, retornando cego e desgraçado, Pozzo declara não se lembrar de quando o destino the abateu, e mais, que nada sabe sobre ontem, e tudo o que vivenciar hoje não estará mais do que esquecido amanhã ${ }^{67}$. Também, os pastorzinhos não se lembram de já terem visto Vladimir e Estragon, não obstante os dois amigos darem a entender que os conhecem como também o teor recorrente de sua desoladora mensagem ${ }^{68}$. A levar em conta a filosofia agostiniana, que identifica a memória ao próprio espírito, os personagens de Esperando Godot reúnem de modo insuficiente as próprias vivências sob uma unidade, ajustando-as mal sob o designativo 'eu'. Sem memória, estão privados de 'eu', e assim de uma história. "Estamos sempre achando alguma coisa, não é Didi, para dar a impressão de que existimos?"69, comenta Estragon. E, com efeito, estes seres amnésicos praticamente não existem: não são personagem (ao modo clássico), e não participam de um enredo (a não ser precariamente). Se sua condição ficcional já os eterifica, eterifica-os muito mais seu completo esquecimento/alheamento do cânon dramático.

\footnotetext{
${ }^{66}$ Pozzo, após descrever o ocaso, confessa ter uma 'memória defeituosa'. Idem, ibidem, pp. 76.

${ }^{67}$ Idem, ibidem, p. 181.

${ }^{68}$ Ao ouvir a voz do pastorzinho no 1ํato, Estragon desabafa: "Lá vamos nós de novo!" (Idem, ibidem, p. 95). E, no $2^{\circ}$ ato, é Vladimir que, ao ouvir a voz do pastorzinho, desabafa: "Aí vamos nós de novo. (Pausa. Ao menino) Não está me reconhecendo?" (Idem, ibidem, p. 186).

${ }^{69}$ EG, fsa, p. 138.
} 
- Pode-se dizer que o mal das duas duplas é o tempo. A peça registra, assim, dois modos de estar no tempo, ou de sofrê-lo. "O tempo parou", comenta Vladimir, no $1^{\circ}$ ato, ao que Pozzo, levando seu patacão ao ouvido, objeta: "Não tenha tanta certeza, senhor, não tenha tanta certeza. (...) Tudo que quiser, menos isso"70 ${ }^{\prime 7}$ Vladimir e Estragon vivem a estagnação do tempo (aeternitas), a espera. Em seu universo está interdita a mudança (de cena, de fortuna), e se há movimento, é um movimento cíclico (o dia termina para recomeçar de modo idêntico). O tempo estagnado da espera, sofre-o também o público, que juntamente com os dois amigos, aguarda a chegada de Godot. O tempo de Pozzo e Lucky, por sua vez, é linear e seu percurso, marcado pela decadência (tempus edax rerum). Por exemplo, nos minutos que convive com Vladimir e Estragon, no $1^{\circ}$ ato, Pozzo perde, um após o outro, seu cachimbo, seu vaporizador e seu relógio, objetos-sinais de uma certa distinção social. O passar dos dias, para Pozzo e Lucky, modifica-os. "Eles mudaram bastante", comenta Vladimir a Estragon, quando, no $1^{\circ}$ ato, os dois viajantes partem. E no $2^{\circ}$ ato, o tempo implacável subtrai a visão de Pozzo e a voz de Lucky. Pozzo cego perde a noção do tempo passado: "O cegos não têm noção do tempo. (...) As coisas do tempo eles não vêem""71. E, com mais ênfase, explica: "Não me lembro de ter encontrado ninguém ontem. Mas amanhã não vou me lembrar de ter encontrado ninguém hoje. Não conte comigo para esclarecer nada..." ${ }^{\text {272 }}$. A cegueira confina Pozzo ao presente, e, deste modo, não há resposta

\footnotetext{
${ }^{70}$ EG, fsa, p. 73.

${ }^{71}$ EG, fsa, p. 176.

${ }^{72}$ EG, fsa, p. 181.
} 
possível para a insistente curiosidade de Vladimir em saber quando um ficou cego e o outro, mudo. “...Quando! Quando! - irrita-se Pozzo - Um dia, ..., um dia como os outros, ficou mudo, um dia fiquei cego, um dia, ficaremos todos surdos, um dia, nascemos, um dia, morremos, no mesmo dia, no mesmo instante, não basta para vocês?"73. Se para Vladimir e Estragon os dias são iguais por estarem sempre sob o signo da espera (ou suspensão de um desfecho), para Pozzo e Lucky os dias parecem iguais, porque a constante mudança de fortuna (entenda-se: de um mal para um mal maior) a que estão submetidos, nivela-os.

\section{$\underline{4 . \text { Aqui é o Inferno }}$}

Considerar a peça a partir de seu esquema formal, figurado na canção circular, permite, ao mesmo tempo que um distanciamento das interpretações metafísicas e humanistas ${ }^{74}$ uma maior atenção a seus aspectos intrateatrais ${ }^{75}$. Beckett procura sutil e intencionalmente realçar a teatralidade da peça (que não se confunde com a ilusão teatral). A exigência de um desfecho (oriunda da

\footnotetext{
${ }^{73}$ EG, fsa, p. 183.

${ }^{74}$ Tais interpretações derivam principalmente da obra O Teatro do Absurdo de Martin Esslin, que entendem a peça como representação de instâncias transcendentais da condição humana, e têm como inspiração conceitual um tipo de existencialismo parisiense mitigado (sem suas conseqüências políticas). Cita-se também nesta linha, o crítico Alain Robbe-Grillet. (Cf. Boxall, Peter (editor); Samuel Beckett: Waiting for Godot, Endgame, Cambridge: Icon Books, 2000) 75 Intrateatral é um termo forjado e proposto neste ensaio como alternativa ao termo metateatral. Metateatro entende-se como teatro dentro do teatro, ou teatro que discorre sobre teatro. Intrateatro quererá indicar o jogo dramático que se mostra como tal, como que liberto de um enredo, e expondo a crua nudez de seu enervamento. Como diz Bruno Clément: "Há efetivamente, nesta peça, as marcas de uma reflexão sobre as formas e, portanto, sobre a essência do drama...". (Clément, B.; opus cit., p. 335)
} 
dramática tradicional), por exemplo, é subvertida em Esperando Godot pela repetição. Ora, escolher a repetição (ou circularidade) como percurso da obra é acatar a virtualidade repetitiva do texto teatral, atualizado dia após dia durante as temporadas ${ }^{76}$. Um outro exemplo: a unidade de lugar. Pode-se dizer, que em Esperando Godot tal unidade comparece de modo diferente daquele prescrito pelo teatro clássico. Se as três unidades eram requeridas para efeito de verossimilhança, para que o espectador pudesse fruir melhor a fábula, aqui a unidade de lugar denuncia a fragilidade da fábula, e reafirma para o espectador o confinamento dos personagens a seu único sítio possível. Já foi descrita acima, a cena em que Estragon, buscando desesperadamente fugir, colide com a parede dos fundos, não encontra vazão pelas coxias, apavora-se com a visão do público a sua frente, resignando-se, por fim, a seu lugar de personagem, o intransponível palco. O acontecimento teatral é apresentado assim nos eixos temporal-espacial, como circularidade e confinamento. Nem limbo, nem purgatório, como diz Estragon, definindo este teatro: "Aqui é o inferno! ${ }^{177}$.

\footnotetext{
${ }^{76}$ Pode-se dizer também que a repetição dos atos reforça a unidade de ação. Como explica Bruno Clément: “... o que 'transborda' de cada parte da peça, antes de subir e depois de cair o pano, só pode ser sempre a mesma coisa. Assim se funda a verdadeira unidade de ação, bem mais profunda e autêntica que a clássica, a qual devia, a cada peça, refazer suas provas; bem mais abrangente também porque vale, dir-se-ia, para todos os atos. Pela regra, pela exigência, clássicas por excelência, da verossimilhança, sucede a preocupação, ou melhor, a declaração da preocupação com a realidade. O que é circunstancial no teatro clássico torna-se no teatro beckettiano fundamental". (Idem ibidem, pp. 326-7)

${ }^{77}$ EG, fsa, p. 147.
} 
Este inferno, configurado sobre o modelo dramático tradicional, mas em chave negativa $^{78}$, é fundamentalmente teatral. Sartre em Huis Clos engendrara seu inferno sobre o modelo desiderativo (a angústia do desejo insatisfazível) para atingir a máxima filosófica 'o inferno são os outros'. Em nenhum momento o filósofo francês questiona o meio artístico utilizado para 'passar sua mensagem ${ }^{79}$. E, no entanto, Esperando Godot e Huis Clos são tratadas como peças irmãs por Peter Szondi em Teoria do Drama Moderno ${ }^{80}$. Problematizar este parentesco, diferenciar seus projetos 'infernais' poderia realocar Beckett na reflexão sobre o drama moderno.

A breve consideração sobre Huis Clos e a brevíssima sobre Esperando Godot, encontradas em Teoria do Drama Moderno, insere-as na contramão de um processo histórico: segundo Szondi, o teatro, a partir de fins do século 19, abandona gradativamente a dramática pura (de origem renascentista), e passa a incluir elementos épicos em sua construção. Assim, atinge-se 0 patamar dos teatros épicos de Brecht, Piscator, Wilder, entre outros.

O drama erigia-se triplicemente como 'acontecimento presente intersubjetivo', ou seja, como uma trama, em tempo praticamente real, levada a cabo pelos personagens - sem a presença de um narrador -, através do conflito dialogado. O drama moderno subverte a antiga base, adotando o elemento

\footnotetext{
${ }^{78}$ Aqui faltam desfecho, conflito, trama, curva dramática, exposição, reconhecimento, catarse etc.

79 "... a forma, que em Satre é aquela da peça de tese, concebida de modo um tanto tradicional, nada audaciosa, visando mais o efeito, em Beckett assume o expressado e o altera" ("Intento de entender Fin de Partida" in Notas sobre Literatura, Madrid: Akál, 2003).

80 Szondi, Peter; Teoria do Drama Moderno, tradução de Luiz Sérgio Rêpa, São Paulo: Cosac\&Naify, 2001.
} 
narrativo, e expandindo assim seu alcance artístico para além da esfera interpessoal presente: pode-se abordar, deste modo, questões contemporâneas, políticas, psíquicas, históricas. Se, num primeiro momento, neste processo histórico em direção ao épico, as peças (de lbsen, Tchèkhov, Hauptmann etc) incorrem na contradição entre enunciado da forma e enunciado de conteúdo ${ }^{81}$ (presas que estavam ao modelo dramático), com o passar do tempo surgem textos que ensaiam de várias maneiras a solução da contradição anterior. Dois exemplos para entender esta mudança: Ibsen tentara ajustar o passado ao presente cênico, por meio de relatos 'disfarçados' de diálogos $^{82}$, e criara assim um conflito entre forma dramática e conteúdo romanesco; Thorton Wilder, em Nossa Cidade, pode retratar a passagem de décadas na vida de uma cidade sem incorrer em contradição com a forma, pois inclui um diretor de cena (narrador) na peça, que apresenta e monta a história para o público. O conteúdo romanesco - ou seja, décadas de história -, encontra aqui sua forma: a narração.

Contudo, nem todo texto teatral tendeu para o épico no século passado, e muitos, segundo Szondi, buscaram a 'salvação' do drama, acomodando-se a um de seus esteios. A maior parte deste teatro regressivo incorreu na contradição forma e conteúdo. A peça de conversação, por exemplo, pretendeu salvar o diálogo. O assunto (ou conteúdo) deste teatro - a saber, voto feminino,

\footnotetext{
${ }^{81}$ Pasta Júnior apresentando a genealogia da teoria de Szondi, faz notar seu débito para com Hegel, Luckàcs, Benjamin e Adorno, e ressalta o caráter dos enunciados de conteúdo: "os 'conteúddos' temáticos, advindos da vida social, não são, por oposição à forma artística, algo informe a que esta daria forma: eles já constituem por seu turno, enunciados, isto é, são formados”. (Pasta Júnior, José Antônio; 'Apresentação' in Szondi, Peter; opus cit, p. 12)

${ }^{82}$ Nas palavras de Szondi, "quando o passado predomina, ele [o diálogo] se torna a sede monológica da reminiscênica". (Idem, ibidem, p. 105)
} 
amor livre, socialismo etc -, que se queria moderno, entra em contradição com a forma adotada, próxima da dramática clássica. Mantém-se a presença dialógica dos personagens, mas estes já não têm o que dizer de si mesmos, não se revelam, comparecendo apenas para desenvolver o tema da peça, que os ultrapassa. O diálogo que se definia antes como "espaço coletivo onde a interioridade das dramatis personae se objetiva[va]"83, que se definia como motor da ação dramática, torna-se agora conversação. Também as chamadas peças de confinamento fazem dissonar forma e conteúdo. Aqui, "homens isolados, aos quais corresponderia formalmente o silêncio ou o monólogo, são forçados por fatores externos a voltar ao dialogismo da relação intersubjetiva" ${ }^{\prime 4}$.

No entanto, existem peças - como Der Schwierige (de Hofmannsthal), Huis Clos, Esperando Godot, entre outras - que não se inclinam à épica, que se mantêm próximas ao drama, que não desdenham os complexos temas contemporâneos, e, ainda assim, resolvem sua presumível contradição interna. Der Schwierige, considerada por Szondi como peça de conversação, apresenta a aristocracia vienense - que vive na conversação -, através do personagem conde Bühl, que critica a linguagem e o alcance do diálogo. Assim, pode-se dizer que a forma (conversação) concorda com o tema: a problematização da conversação. Huis Clos, por sua vez, considerada por Szondi como peça de confinamento, encerra seus personagens no inferno, forçando a relação intersubjetiva no plano formal, para, no plano temático, expor a impossibilidade das relações sociais ("o inferno são os outros"). Nestes

\footnotetext{
${ }^{83}$ Idem, ibidem, p. 105.

${ }^{84}$ Idem, ibidem, p. 113.
} 
dois exemplos, "o elemento puramente formal se inverte em elemento temático" ${ }^{, 85}$, e de um modo crítico: usa-se a conversação para criticar a conversação; força-se a relação interpessoal para mostrar sua impraticabilidade.

Aplicar, no entanto, a Esperando Godot este modelo dicotômico impõe dificuldades para o entendimento do texto. Ao fazê-lo, Szondi força uma leitura metafísica da peça, que encobre seu caráter intrateatral. Para Szondi, Esperando Godot é uma peça de conversação, na qual esta "torna-se temática" "86. a conversa esvaziada revelaria a "misère de l'homme sans Dieu",87, ou seja, a ruína presente na forma denunciaria a ruína existencial humana. A preocupação de Beckett, no entanto, revela-se mais dramatológica do que existencial $^{88}$. Não é fácil separar aqui enunciado formal de enunciado temático. Pode-se conjecturar que se trata de um texto teatral investigando, por meio de sua forma, o que seria o drama, sem remissão a um enredo, ou ainda, investigando o que sustenta o mecanismo dramático quando toda possibilidade semântica ruiu ${ }^{89}$. Mais do que uma peça de conversação, portanto, esta mostrar-se-ia como um ensaio sobre os únicos índices irredutíveis do drama: o

\footnotetext{
${ }^{85}$ Idem, ibidem, p. 107.

${ }^{86}$ Idem, ibidem, p. 108.

${ }^{87}$ Idem, ibidem. (em francês no original)
}

${ }^{88}$ Apesar de Beckett e o existencialismo, como nota Fábio de Souza Andrade, partirem de um ponto em comum: "a de que o mundo administrado, nossa realidade, é totalitária e desprovida de significado a ponto de enfraquecer os modos de reação subjetivos possíveis". (Andrade, Fábio de Souza; Samuel Beckett: O Silêncio Possível, São Paulo: Ateliê, 2001, p.32)

${ }^{89}$ As implicações mais filosóficas desta dramaturgia, distintas de suas leituras existencial e humanista, serão abordadas no próximo capítulo, tendo como ponto de apoio o ensaio de Adorno sobre Fim de Partida (Adorno, T. W.; "Intento de entender Fin de Partida" in Notas sobre Literatura, Madrid: Akal, 2003) 
espaço e o tempo. Com a ressalva, contudo, de que não há uma discussão sobre espaço e tempo, mas uma ampliação formal de sua função teatral.

O inferno de Sartre toma o drama de assalto para defender uma concepção filosófica. O inferno de Beckett é o próprio drama, meditado passo a passo, sofrido em sua contemporânea agonia, em sua incerta e ainda obscura ressurgência. 


\title{
II. Fim de Partida \\ ¿ Paradoxo e Inconcludência əo
}

\author{
"Le temps ne passe pas, \\ ne vous laisse pas [...] \\ il vient s'entassser autour de vous, \\ instant par instant, \\ de tous les côtés, \\ de plus en plus haut, \\ de plus en plus épais" \\ Samuel Beckett, \\ L'Innommable
}

"Se a cada palavra obtemos vitória sobre o nada, é tão-somente para sofrer melhor o seu domínio"

Cioran, Breviário de Decomposição

"That corpse you planted last year in your garden/ Has it begun to sprout?/ Will it bloom this year?"

T.S. Eliot, The Waste Land 


\section{O Monte Impossível}

Fim de Partida desenrola-se articulando dois planos simultâneos, o fabular (nos registros dramático e narrativo ${ }^{90}$ ) e o teatral.

No plano fabular, a situação dramática figura quatro personagens confinados em um abrigo, ou bunker, fora do qual grassa a destruição completa da natureza e da civilização. São eles Hamm, cego e paralítico; Nagg e Nell, aleijados; e Clov, coxo. Com as provisões acabando, esta família desditada aguarda o fim revolvendo o passado e buscando infligir-se mais dor. A situação narrativa, por sua vez, se dá a partir da situação dramática, e manifesta-se na forma de um romance em processo de criação enunciado oralmente por Hamm. O romance discorre sobre um pai moribundo que, após rastejar por uma paisagem morta, chega, às vésperas do natal, à propriedade de Hamm, e pede pão para o filho, abandonado sem forças há muitas horas dali.

O que se chama de plano teatral, apóia-se em aspectos teatrais irredutíveis: a instituição de um começo, uma duração e um final, e a potencial repetição deste processo.

O dois planos organizam-se, no entanto, de modo a confundir o espectador. Ao mesmo tempo que esclarecem, também obscurem o

${ }^{90}$ Como explica Kristin Morrison, “... Beckett compôs uma 'crônica' substancial para Fim de Partida, oferecendo um dos melhores exemplos de uma narrativa longa como parte essencial do drama. [...] A peça termina, quando a narrativa termina". (Morrison, Kristin; Canters and Chronicles: The use of the narrative inthe plays of Samuel Beckett and Harold Pinter, London, Chicago: The University of Chicago Press, 1986, pp. 27-8) 
entendimento um do outro, ao mesmo tempo que parecem convergir, distiguem-se irreconciliavelmente. Assim, instauram incertezas e incongruências e confirmam o universo paradoxal confessado logo ao início da peça:

Clov: (olhar fixo, voz neutra) Acabou, está acabado, quase acabando, deve estar quase acabando. (Pausa) Os grãos se acumulam, um a um, e um dia, de repente, lá está um monte, um [pequeno monte], o monte impossível. ${ }^{91}$

O paradoxo do monte (ou sorites), referido por Clov, remonta ao filósofo megárico Eubulides de Mileto (400 a.C.), e pertence àquele gênero de paradoxos que contêm predicados vagos e desafiam lógicos e matemáticos até os dias de hoje e2. $^{92}$

A qualidade vaga do termo 'monte' é tal que tolera mutações pontuais as quais não comprometem seu sentido. Assim, diz-se que, se $\boldsymbol{n}$ grãos de sal é um monte, $\boldsymbol{n}$-1 será também um monte. Contudo, aplicando o princípio de

91 Beckett, Samuel; Fim de Partida, tradução de Fábio de Souza Andrade, São Paulo: Cosac\&Naif, 2002, p.38. Será utilizada neste capítulo esta edição da peça, estando indicado entre colchetes, nas citações, tanto os cortes efetuados, quanto propostas de tradução mais literais, quando houver necessidade. A partir daqui, indicar-se-á esta edição por FP. Observese que também foi consultada a tradução de Rubens Rusche, Fim de Jogo, utilizada na montagem com sua direção de 1996.

${ }^{92}$ Ainda que não se detenha na questão do paradoxo do monte, o artigo "Paradox in Beckett" de Rolf Breuer (Jstor - The Modern Language Review, vol 88, n.3, pp.559-580) deve ser lembrado como ótima referência ao tema. Sobre a questão específica do paradoxo do monte, foram consultados os seguinte livros: Beall, J.C. (editor), Liars and Heaps - New Essays on Paradox, Oxford: Clarendon Press, 2003; e Keefe, Rosanna, Smith, Peter (editors); Vagueness: A reader, Cambridge, London: MIT Press, 1997. 
tolerância sucessivamente chega-se a conclusão paradoxal de que 1 grão de sal é um monte.

Mais freqüente em sua forma subtrativa, pode-se, não obstante, elaborar este paradoxo na forma aditiva: assim, se $\boldsymbol{n}$ grãos de sal não é um monte, então $n+1$ não é um monte; se $n+1$ não é um monte, então $(\boldsymbol{n}+1)+1$ não é um monte; se $(\boldsymbol{n}+1)+1$ não é um monte, então $\{(\boldsymbol{n}+1)+1\}+1$ não é um monte. Procedendo deste modo sucessivamente, alguém estará forçado a concluir, no plano da razão teórica, que aquele gigantesco monte que se the ergue na frente (no plano empírico) não é um monte ${ }^{93}$.

O 'monte impossível' de Clov espelha a estrutra paradoxal de Fim de Partida, arquitetada sobre dois planos que se desencontram ${ }^{94}$.

Se, por um lado, a peça acaba, com Hamm estancando o fluxo de suas palavras ao cobrir o rosto com um trapo, por outro lado, a peça não conclui nem dramática nem narrativamente. Beckett não concede ao espectador 0 prêmio de um sentido que possa restaurá-lo de hora e meia de incertezas. Pela lógica teatral a peça termina - cai o pano -, pelas lógicas dramática e narrativa

\footnotetext{
${ }^{93}$ Beckett explicou assim o paradoxo do monte a seus atores do Schiller-Theater em Berlim em 1967: "O que é um monte? Talvez ele não possa nem existir, uma vez que um grão não é um monte, e dois também não: um não-monte mais um não-monte não pode produzir nenhum monte, e assim por diante... Ergo: o grão deve ser um monte". (Gontarski, S. E. - edited by; Theatrical Notebooks of Samuel Beckett: Endgame, London: Faber and Faber, 1992, p.47)

${ }^{94}$ Bruno Clément já notara isso: "...a obra dramática de Samuel Beckett propõe freqüentemente ao espírito do espectador uma dualidade de planos; e é a inadequação fabricada de um plano a outro que constitui, como o destino na tragédia clássica, a dinâmica das peças." (Clément, Bruno; L'Oeuvre sans Qualités - Rhétorique de Samuel Bekcett, Paris: Seuil, 1994, p.328)
} 
não remata. O final da peça simplesmente interrompe duas ações (uma referente à narrativa, outra à situação dramática) em iminência de desfecho. Beckett parece denunciar, assim, a impotência lingüística - vividas nas situações dramática (dialógica) e narrativa -, em que palavras deshistoricizadas jorram 'in-conseqüentes' e 'in-significantes' de seus elocutores, palavras, por isso mesmo, condenadas a luzir e apagar-se no presente da enunciação.

Assim como os grãos, que, acumulados um a um sucessivamente, formam um monte no plano empírico, enquanto em plano lógico-paradoxal não o formarão jamais, Fim de Partida encena o conflito inconciliável entre devir dramático (o qual pressupõe palavras fomentadoras de futuro) e impotência verbal.

\section{O Fim e o Jogo}

O próprio título, Fim de Partida, reúne temas-chave do texto: o fim e o jogo.

Jogo compreendido como jogo teatral ${ }^{95}$, cujas regras mantêm-se no seu mínimo e irredutível viger: um início, uma duração, um final, e a repetição de

\footnotetext{
95 Jane Alison Hale lista todos os momentos em que os personagens de Fim de Partida refletem sobre sua fala e sobre suas ações, valendo-se do "vocabulário e da objetividade cínica de um crítico dramático experimentado". Assim nomeiam como tais suas deixas, apartes, solilóquio, saída de cena, etc. (Alison Hale, Jane; "Endgame: How are your eyes", in Connor,
} 
todo o processo em dias seqüentes. Se no início está o fim, se a duração arrasta instantes inúteis, se o final só remata pelo cair do pano (ou trapo), deixando sem desfecho a história, não importa, as regras impõem-se, e os personagens, atônitos, submetem-se ao jogo como ao destino.

Em certo nível semântico a peça significa o fim deste jogo, que se mantém como remedo do teatro passado, e vislumbra, na devastação que the circunda, formas fantasmáticas para um teatro futuro.

"Minha... (bocejos) ...vez. (Pausa) De jogar"96, anuncia Hamm, parodiando um enxadrista. A expressão 'fim de partida' designa a última etapa de uma partida de xadrez, quando há poucas peças no tabuleiro, quando os peões tornam-se mais importantes (podem deixar 0 tabuleiro, e ser promovidos), e o rei, antes em guarda contra o xeque-mate, deve, então, ocupar o centro do jogo e atacar. Postado no centro do palco, cego e paralítico, entronado na cadeira com rodízios emperrados, o 'rei' Hamm ataca, porém com palavras. Claudicante, mas móbil, o 'peão' Clov parece buscar sua emancipação.

Steven (editor); Waiting for Godot and Endgame, Hong Kong: The McMillan Press, 1993, p.78). Hugh Kenner indica também o aspecto metalingüístico da peça em que os personagens se comportam como atores, ao usarem seu jargão; em que a própria peça se apresenta como tal, representando-se a si mesma. Por exemplo, quando Clov, olhando através da janela do abrigo, relata que não há nada além, Kenner pontua: "pois o que se pode ver através de janelas cenográficas?" (Kenner, Hugh; A Reader's Guide to Samuel Beckett, Syracuse: Syracuse University Press, 1996, p.121)

${ }^{96}$ FP, p.39. "Me to play", em inglês, remete ao modo de abrir uma partida de xadrez:' White to play'. Gontarski, opus cit. p.49. 
Mas as palavras que atacam ferem reflexivamente quem as enuncia, e há motivos bastante convincentes contra a gana de transpor o tabuleiro: fora dali é a morte, nem terra, nem mar, nem sol, nem chuva, zero, zero, zero. Afinal, se esta é uma partida de xadrez, será de tal sorte que, empatada e concorrida por péssimos jogadores ${ }^{97}$, prorroga-se por força de manobras inúteis:

Hamm: É, é isso mesmo, está na hora disso acabar e mesmo assim eu ainda hesito em ter um... (boceja) ....fim ${ }^{98}{ }^{99}$

No interior sem mobílias, que a rubrica prescreve de entrada, repousam cinco 'panos', que substituem a vetusta cortina do teatro ${ }^{100}$. Clov, contra-regra e personagem, recolhe quatro deles, ${ }^{101}$ remedos de cortina. Hamm, logo em seguida, recolherá o último, este, sim, reformador. Trata-se de um trapo

\footnotetext{
${ }^{97}$ Segundo Worton, o próprio Beckett confessou o seguinte: "Hamm é um rei numa partida de xadrez perdida desde o iníio. Desde o início ele sabe que está empreendendo manobras sem sentido. Que não fará progresso nenhum com o gancho [gaff]. [...] Um bom jogador teria desistido há muito tempo. Ele está apenas tentando adiar o fim inevitável. Cada um de seus gestos é mais uma manobra inútil, que protela o fim. Ele é um mau jogador". (Worton, Michael; "Waiting for Godot and Endgame" in The Cambridge Companion to Beckett, Cambridge: Cambridge University Press, 1996, p. 71)

${ }^{98}$ FP, p.39.

${ }^{99}$ Note-se que, enquanto Hamm hesita em ter um fim, Clov o anseia sofregamente. Poder-se-ia entender a peça, assim, como o embate entre dois modos de jogar. Um voltado para o fim, outro para a sua protelação.

100 Como nota Hugh Kenner, "quando o teatro está vazio é prudente manter [os objetos] cobertos contra a poeira. Portanto, somos lembrados desde o começo [da peça] que iremos testemunhar uma exibição dramática empoeirada, repetida e repetida". Kenner, Hugh; Samuel Beckett, A Critical Study, London: John Calder, 1962, p.155).

${ }^{101}$ Clov retira dois panos que cobriam as janelas, um pano que cobria os latões de lixo, outro, que cobria Hamm, sentado na cadeira de rodas.
} 
(stancher, em inglês - trapo usado para estancar o sangue ${ }^{102}$ ), que lhe cobre o rosto e the represa as palavras - ao que parece pelo tempo entre uma apresentação e outra. Reduzida a tapa-bocas, a cortina revela a natureza do palco, pois, puxado o pano (ou trapo), o palco se assume como lugar da palavra.

Mas de qual palavra ${ }^{103}$ ? Não, certamente, da palavra clássica, porta-voz da vontade de sujeitos livres, cujo confronto era o próprio motor da peça. Não desta palavra cujo sentido é inequívoco: o futuro desfecho. Não. O palco dá lugar aqui a uma outra palavra - que não serve ao duelo -, dá lugar à palavra conformada, aquela que pressupõe desigualdade entre personagens, e, assim, submissão de um ao outro.

Hamm: Não vou lhe dar mais nada para comer.

Clov: Então nós vamos morrer.

Hamm: Vou Ihe dar apenas o suficiente para você não morrer. Você vai ter forme o tempo todo.

Clov: Então não vamos morrer ${ }^{104}$.

Hamm: Vá buscar o croque.

Clov vai até a porta, pára.

Clov: Faça isso, faça aquilo, e eu faço. Nunca me nego. Por quê?

Hamm: Você não consegue ${ }^{105}$.

\footnotetext{
${ }^{102}$ Lembre-se que stanch designa também lealdade. O trapo, assim, seria o único elemento fiel a Hamm, que atende às suas necessidades.

${ }^{103}$ Diz Bruno Clément, salientando o lugar destacado da palavra no teatro de Beckett: "o que o teatro de Samuel Beckett põe gradativamente em jogo [...] é um drama que não tem apenas a palavra como meio, mas como assunto dramático. Os dois protagonistas mais comuns dos dramas de Samuel Beckett são, com efeito, uma consciência e um certo estado da (mais freqüentemente da sua) palavra". (Clément, Bruno; opus cit., p.335)

${ }^{104}$ FP; p.43.
} 
Esta palavra, inaugurada de sob um trapo ensangüentado, mas desafeita ao conflito, também não se sustenta enquanto ímpeto para uma ação. Todo impulso é rapidamente atenuado, e por fim esquecido: o desejo de Hamm de parafusar os pais em seus latões é substituído pela vontade de 'fazer xixi'; a disposição de dar 'a volta ao (seu) mundo', deixando-se arrastar por Clov rente às paredes do refúgio, é interrompida na metade do percurso; a ânsia de partir por mar numa jangada, na esperança de encontrar outros mamíferos, é arrefecida pela dúvida quanto a existência de tubarões. Diferentemente do teatro clássico cujas palavras serviam ao progresso da ação, as palavras aqui estão impedidas de porvir, e por isso seu desempenho fica restrito a modos verbais 'in-conseqüentes'. Mesmo o romance de Hamm, que - na articulação interna da peça - assume a função de motor dramático, acaba por não fomentar um devir, pois, ao fim e ao cabo, confunde-se com o plano dramático ${ }^{106}$.

A palavra encontra-se esterilizada também enquanto vocábulo, e não serve mais.

Hamm: Vá buscar o óleo.

Clov: Pra quê?

Hamm: Pra lubrificar as rodinhas.

Clov: Eu lubrifiquei ontem.

Hamm: Ontem! Que quer dizer isso? Ontem!

${ }^{105}$ FP; pp.95-6.

106 "A narração, no teatro de Samuel Beckett, é, com raras exceções, não apenas a condição, mas a própria essência do drama [...]". (Clément, Bruno; opus cit., p.331) 
Clov: (com violência) Quer dizer a merda do dia que veio antes desta merda de dia. Uso as palavras que você me ensinou. Se não querem dizer mais nada, me ensine outras. Ou deixe que eu me cale ${ }^{107}$.

Clov: [...] Pergunto às palavras que sobraram: sono, despertar, noite, manhã. Elas não têm nada a dizer. [... $]^{108}$

Neste universo em que é sempre 'a mesma hora de sempre', em que faz sempre o mesmo tempo de sempre, em que a luz não varia nas matizes noite, aurora, dia, crepúsculo, mas se mantém num invariável tom cinza, neste universo em que nada parece capaz de transformação (e, não obstante, pode terminar), aqui, todo o vocábulo afeito a estados transitórios (sono, despertar, noite, manhã, ontem) obsolesce.

A palavra ontem, por exemplo, só terá sentido referida a uma época remota e derrocada, quando havia natureza e mundo e quando perguntas obtinham respostas $^{109}$. Nell, por exemplo, se torna nostálgica ${ }^{110}$ à menção da palavra 'ontem', deslocando-a de seu sentido imediato, para aquele longínquo e perdido:

Nagg: Meu dente caiu.

Nell: Quando isso?

Nagg: Ontem ainda não tinha caído.

\footnotetext{
${ }^{107}$ FP; pp.96-7.

${ }^{108}$ FP; p. 146.
}

109

Hamm: Gosto das velhas perguntas. (Com ânimo) Ah, velhas perguntas, velhas respostas, não há nada como elas. [...]. (FP, P.88-9)

${ }^{110}$ Como explica Clément, é a nostalgia que funda a temporalidade beckettiana: "A nostalgia, discreta e tocante (de Winnie), ou amarga e derrisória (de Clov), é, paradoxalmente, aquilo que funda a temporalidade beckettiana". (Idem ibidem, p.269) 
Nell: (elegíaca) Ah ontem! $!^{111}$

Nagg: Será que não daria pra você me coçar antes?

Nell: Não. (Pausa) Onde?

$[\ldots]$

Nagg: [...] No buraco.

Nell: Que buraco?

Nagg: O buraco, qual outro? (Pausa) Você não podia? (Pausa)

Ontem você me coçou ali.

Nell: (elegíaca) Ah ontem! $!^{112}$

Note-se, no entanto, que este ontem não resguarda um tempo imaculado, apenas indica 'o tempo linear'. O tom elegíaco de Nell transporta-a para uma época trágica, quando ela e Nagg perderam as pernas num acidente de tandem, este 'ontem' transporta-a para a data de sua lua-de-mel, quando não se ria de felicidade, mas por ouvir uma piada ${ }^{113}$. Contudo, apesar dos pesares, o tempo passava 'naturalmente':

[Hamm: Morreu naturalmente, aquele velho médico?

Clov: Ele não era velho.

Hamm: Mas morreu?

Clov: Naturalmente. $]^{114}$

Agora que não há mais natureza - mostrador implacável do trabalho das horas - e as palavras não servem mais como meio para um télos, o tempo, simplesmente, encolhe e o fim anelado tarda. Não fosse pelas regras do jogo a

\footnotetext{
${ }^{111}$ FP, p.57.

${ }^{112}$ FP, pp.63-4.

113
}

Nagg: Você ria tanto que quase emborcamos. Mais um pouco e teríamos nos afogado.

Nell: Era porque me sentia feliz.

Nagg: Feliz coisa nenhuma, era por causa da minha história. (FP, P.66)

114 FP, p.70. 
que estão submetidos, que prescreve um final, os personagens de per se, jogando com palavras fracas, não alcançariam um termo.

No teatro clássico, as cenas eram demarcadas pela entrada ou saída de personagens. Em Fim de Partida, as 'saídas' de Clov pontuam o próprio progresso da peça, e provocam, por quatro vezes, o comentário de Hamm: "Estamos progredindo". Assim, um dispositivo superficial, referente à estrutura externa $^{115}$ da peça - entrada e saída de personagem -, substitui o dispositivo estrutural interno faltante, qual seja, o conflito como motor da história.

Mas a ardilosidade deste "estamos progredindo" não basta para desenvolver a trama, e a tentativa malograda em avançar é lamentada por Hamm: "isso não anda"116; "isso anda meio sem graça"117; "isso não vai acabar nunca"118. Por duas vezes Hamm, lastimando a imutabilidade de sua situação, é corrijido por Clov, que acena com a esperança de um fim (ou monte impossível):

Hamm: Você não está cheio disso?

Clov: Estou! (Pausa) Do quê?

Hamm: Desse... dessa... [coisa].

Clov: Desde sempre. (Pausa) Você não?

Hamm: (melancólico) Então não há razão para que isso mude.

Clov: Pode acabar. ${ }^{119}$

\footnotetext{
115 Cf. Scherer, Jacques; La Dramaturgie Classique en France, Mayenne: Nizet, 1997, pp.214-28.

${ }^{116}$ FP; p.52.

${ }^{117}$ FP; P.55.

${ }^{118}$ FP; p.67. Note-se que os comentários de Hamm, em relação ao andamento da peça, cessam quando ele transfere para seu romance in progress a expectativa por um final.

${ }^{119}$ FP; p.42.
} 
Hamm: Você não acha que isso durou o bastante?

Clov: Acho! (Pausa) o quê?

Hamm: Esse... essa... [coisa].

Clov: Sempre achei. (Pausa) Você não?

Hamm: (abatido) Então é um dia como os outros.

Clov: Enquanto durar. ${ }^{120}$

Clov intui o preceito do jogo a que estão submissos. Alguma coisa acontece à revelia de as suas (anti)ações e contra todas as expectativas:

Hamm: (com angústia) Mas o que está acontecendo, o que está acontecendo?

Clov: Alguma coisa segue o seu curso ${ }^{121}$.

Esta coisa, ou jogo, da qual Hamm 'está cheio', esta coisa que estranhamente e até inexplicavelmente segue o seu curso, pode, no entanto, terminar.

Mas o fim não será um consolo. Na pergunta que Nell e Clov se fazem, "Por que esta comédia, todos os dias?"122, espreita uma espécie de maldição constitutiva do jogo: a abertura da performance teatral à reencenação, o fato de que a performance teatral é potencialmente sem fim. "O fim está no começo e no entanto continua-se"123, declara Hamm, corroborando a estrutura circular da peça com uma antinomia.

Os tableaux final e incial assemelham-se, como se um preparasse 0 outro. Não são, porém, idênticos. A ordem almejada por Clov, o seu sonho de

\footnotetext{
${ }^{120}$ FP; p.99.

${ }^{121}$ FP; p.55.

${ }^{122}$ FP; p.57 e p.80.

${ }^{123}$ FP; p. 128.
} 
"um mundo onde tudo estivesse silencioso e imóvel, e cada coisa em seu lugar final, sob a poeira final”124, só é alcançado pelo tempo que separa uma apresentação da outra e não perfeitamente.

O universo em Fim de Partida é anti-aristotélico ${ }^{125}$. Aqui o que acontece não caminha mais para seu lugar ou tópos natural. E assim, a peça como um todo não progride (nem causalmente nem teleologicamente), e não revela, assim, um sentido. No primeiro terço da história Hamm pergunta a Clov: "Não estamos começando a... a... significar alguma coisa?"126. Mas a resposta do outro consiste em um riso breve, desdenhoso. Só ao final, Hamm resigna-se com a qualidade sem qualidades deste jogo:

Hamm: Momentos nulos, nulos desde sempre, mas que são a conta, fazem a conta e fecham a história. ${ }^{127}$

O jogo, sem motivação para um fim (nem para um começo), está prestes a terminar, a voz ou fala que o sustenta será interrompida pela cortina-trapo, as palavras cessarão seu fluxo e os personagens jazerão em coma.

\footnotetext{
${ }^{124}$ FP; p.112. Como explica Souza Andrade "a ordem aspirada por Malone é análoga àquela sonhada por Clov em Fin de Partie: o silêncio final de cada coisa devolvida ao pó, inerte, inanimada". (Andrade; Fábio de Souza, Samuel Beckett: 0 silêncio Possível, São Paulo: Ateliê, 2001, p.120)

${ }^{125} \mathrm{O}$ anelo de Clov e Malone pela ordem, por cada coisa em seu lugar é impossível. Em Malone Morre lê-se: "Mas no coração das trevas, havia o silêncio, o silêncio da poeira e das coisas que nunca sairiam do lugar, se dependesse delas. E o tique-taque do invisível relógio era como a voz do silêncio que, um dia, como a treva, também iria triunfar. E então tudo seria silencioso e escuro e as coisas estariam, finalmente, em seu lugar para sempre" (Beckett, Samuel; Malone Morre, São Paulo, Brasiliense, 1986, p.36).

${ }^{126}$ FP; p.81.

${ }^{127}$ FP; $p .147$.
} 
Até que tudo se repita ${ }^{128}$.

\section{Além é o outro Inferno}

Como apontou Adorno ${ }^{129}$, a situação em Fim de Partida é aquela na qual já não há mais natureza, em que a reificação do mundo se completou. Tudo está transformado por mãos humanas, transformado, porém, em ruínas ${ }^{130}$. Pelas duas janelas do abrigo, não se avistam as coisas próprias da terra, nem do mar, nem do céu. Segundo a descrição de Clov, o que a paisagem oferece aos olhos é "zero, zero, zero".

Ainda que o renitente Hamm alegue que dentro do abrigo todos respirem e mudem, percam os cabelos e os dentes, a juventude e os ideais ${ }^{131}$ - estando sujeitos aos efeitos decadenciais da natureza -, a ruína comum, no entanto, é residual, como a folha que desprega de uma árvore morta. A pulga e o rato, por

\footnotetext{
${ }^{128}$ A circularidade em Fim de Partida, contudo, pode ser encontrada em escala menor dentro da própria peça, naquilo que Luiz Fernando Ramos chamou de "reinícios dos vários ciclos contidos na circularidade de Fim de Partida", quando os personagens remetem, mais de uma vez, à sua rotina dramática: "Por que esta comédia todos os dias?" ou "alguma coisa segue o seu curso". (Ramos, Luiz Fernando; O Parto de Godot e outras encenações imaginárias: a rubrica como poética da cena, São Paulo: Hucitec/Fapesp,1999, p.59)

${ }^{129}$ Adorno, T. W.; "Intento de entender Fin de Partida" in Notas sobre Literatura, Madrid: Akal, 2003, p.274.

${ }^{130}$ A Dialética do Esclarecimento já previa que 'a terra totalmente esclarecida resplandece sob o signo de uma calamidade triunfal'. (Adorno, T.W.; Horkheimer, Max; Dialética do Esclarecimento, Rio de Janeiro, Jorge Zahar, 1985, p.19)

${ }^{131}$ Cf. FP; p.51.
} 
sua vez, que comparecem inopinadamente neste quadro desertificado, não trazem esperança de ressurreição da terra, mas denunciam o modus operandi de um mundo que pôde chegar a este estado: pulga e rato são seres passíveis de extermínio ${ }^{132}$.

A aversão à alteridade aliada a seus meios de massacre levam, paradoxalmente, à nivelação de tudo. Fim de Partida retrata, assim, a situação de indiferenciação total entre sujeito e objeto, figura o estado em que a alienação se completa ${ }^{133}$. A enigmática risadinha de Clov, que acompanha sua inspeção do mundo através das janelas do abrigo, parece expressar o prazer de um reconhecimento: sujeito e mundo estamos acabados. Nell de modo inverso, testemunha com seu riso um distanciamento. Ela pode rir de si mesma, remetendo-se ao dia em que foi mutilada, porque, simplesmente, não há mais si-mesma. Só pela condição de completa alienação, entende-se seu cruel aforisma: "nada é mais engraçado que a infelicidade"134.

Os personagens em Fim de Partida não se constituem como sujeitos ${ }^{135}$, são seres ocos atravessados por memórias alheatórias e palavrório estéril.

132
Clov: Tem um rato na cozinha.
Hamm: Um rato! Existem ratos ainda?
Clov: Na cozinha tem um.
Hamm: E você não o exterminou? (FP; pp.108-9)

133 "...Fim de Partida ocupa o nadir daquilo que a construção de sujeito-objeto requisitou no zênite da filosofia: a identidade pura é a daquele que está destruído, a de sujeto e objeto no estado de completa alienação...". (Idem, ibidem, p. 282)

${ }^{134}$ FP; p. 62.

135 "As catástrofes que inspiram Fim de Partida, fizeram saltar pelos ares aquele indivíduo cuja substancialidade e condição absoluta constituía o que tinham em comum Kierkegaard, Jaspers 
A memória, por exemplo, faz emergir um passado que se aliena da situação presente. Nell refugia-se na acalmia de um remoto passeio através do lago de Como; Hamm não se atribui o quinhão de indiferença que parece ter levado, um dia, ao 'apagamento' do médico e de mãe Pegg ${ }^{136}$.

Clov, por sua vez, deixa claro que soam como flatus vocis as palavras que lhe ensinaram para designar o mundo:

Hamm: [...] Fui eu quem foi um pai para você.

Clov: Foi. (Olhar fixo em Hamm) Você foi isso para mim.

Hamm: E minha casa o seu lar.

Clov: É (Longo olhar circular) Esse lugar foi isso para mim. ${ }^{137}$

E ainda:

e a versão sartreana do existencialismo. [...] Fim de Partida destrói esta classe de ilusões. O indivíduo mesmo, enquanto categoria histórica, resultado do processo capitalista de alienação e protesto desafiador contra este, mostrou-se uma vez mais como algo efêmero. A posição individualista se situou no pólo oposto do princípio ontológico de todo existencialismo, inclusive de Ser e Tempo. A dramaturgia de Beckett abandona-o como a um bunker antiquado. [...] Fim de Partida pressupõe que a aspiração do indivíduo à autonomia e ao ser tornou-se inverossímil." (Idem, ibidem, pp.279-280) 136

[Hamm: Morreu naturalmente, aquele velho médico?

Clov: Ele não era velho.

Hamm: Mas morreu?

Clov: Naturalmente.] (Pausa) É você quem me pergunta isso? (FP; p.70)

Hamm: Ausente, sempre. Tudo aconteceu sem mim. Não sei o que aconteceu. (Pausa) E você, sabe o que aconteceu? (Pausa) Clov!

[...]

Clov: (com dureza) Quando a Mãe Pegg pedia óleo para a lamparian dela e você a mandava pastar, naquele momento você sabia o que estava acontecendo, não sabia: (Pausa) Sabe do que ela morrer, a Mãe Pegg? De escuridão. (FP; pp.135-7)

${ }^{137}$ FP; p.89. 
Clov: (olhar fixo, voz neutra) Me disseram, O amor é isso que você está vendo, isso mesmo, veja bem agora como... [...] ....como é fácil. Me disseram, $A$ amizade é isso que você está vendo, nem mais, nem menos, não precisa continuar procurando. Me dissseram, O lugar é aqui, pare, levante a cabeça e repare quanto esplendor. Quanta ordem! Me disseram, Vamos, você não é um animal, pense sobre essas coisas e vai ver como tudo ficará claro. E simples! Me disseram, Quanta ciência se aplica, na cura desses feridos de morte. $^{138}$

As palavras estão esgotadas como tudo o mais. Já foi apontado acima, que impedido de porvir, todo discurso aqui restringe-se a modos verbais 'inconseqüentes'. A imprecação, por exemplo, concentrando um máximo de violência, apenas afirma o curso inexorável do mundo. Desejar que o outro sofra, prever-Ihe uma desgraça é somente afirmar o inevitável. É assim que Nagg amaldiçoa seu filho Hamm:

Nagg: [...] Quando era um menininho e tinha medo no meio da noite, quem você chamava? Sua mãe? Não. Eu. Deixávamos você berrar. Até trancávamos a porta para poder dormir. [...] Espero que chegue o dia em que realmente precise que eu escute você, e precise ouvir minha voz, qualquer voz. (Pausa) Sim, espero viver até lá, para ouvir você me chamando, como quando era um menino, com medo, no meio da noite, e eu era a sua única salvação. ${ }^{139}$

E Hamm faz a seu filho adotivo Clov um cruel voto de infelicidade:

Hamm: [...] Um dia você ficará cego, como eu. Estará sentado num lugar qualquer, pequeno ponto perdido no nada, para sempre, no escuro, como eu. [...] Estará rodeado pelo vazio do infinito, [e] nem todos os mortos de todos os tempos, ainda que ressuscitassem, o

\footnotetext{
${ }^{138}$ FP; p. 145.

${ }^{139}$ FP; p.111.
} 
preencheriam, e então você será como um pedregulho perdido na estepe. ${ }^{140}$

No universo de Fim de Partida, o papel de cada geração é manter a próxima no sofrimento. Clov, no entanto, sem poder contar com uma geração mais jovem, vinga-se naqueles que the precederam enunciando o esgotamento do mundo: 'não há mais natureza, não há mais papa, não há mais cobertores, não há mais roda de bicicleta, e - com deleite ${ }^{141}$ - não há mais calmante'.

Mesmo sem haver referência explícita, a situação encenada e os personagens da peça aparecem sob os signos de Auschwitz e da guerra ${ }^{142}$. As Ardenas e Sedan ${ }^{143}$, onde se deu o acidente que mutilou Nagg e Nell, remetem ao local da última ofensiva alemã na segunda grande Guerra. O abrigo em que se confinam os personagens, com suas pequenas janelas altas, lembra um bunker. O pisar das botas de Clov, que soam como um 'regimento de dragões,' evocam comandos militares de reconhecimento. Os latões de lixo contendo o casal de velhos e a urgência em exterminar a pulga e o rato propagam as sombras do holocausto.

\footnotetext{
${ }^{140}$ FP; p.86.

${ }^{141} \mathrm{O}$ anúncio do esgotamento do calmante, sadicamente adiado por Clov, alcança ferir Hamm a ponto de embargar sua voz. Clov apezinha, então, o sofrimento de Hamm, percebendo sua voz embargada: "Está com dor de garganta? (Pausa) Quer uma pastilha? (Pausa) Não? (Pausa) Pena." (FP, p.132)

${ }^{142}$ A autora Élisabeth Angel-Perez em Voyages au Bout du Possible explora este tema e o desenvolve, traçando um paralelo entre Fim de Partida e uma dramaturgia que leva em conta, em sua forma, um acontecimento como Auschwitz. (Angel-Perez, Élisabeth; Voyages au Bout du Possible: Les thèatres du traumatisme de Samuel Beckett à Sarah Kane, Langres: Klincksieck, 2006)

${ }^{143}$ Pelas Ardenas, as tropas alemãs invadiram a Bélgica na segunda Guerra Mundial, numa manobra surpresa.
} 
O espelhamento, na peça, do estado terminal do mundo aparece miniaturizado e está contido na anedota de Nagg. A velha piada discorre sobre um alfaiate inabilidoso que adia por meses a entrega de simples calças, pois a cada etapa da confecção estraga ora os fundilhos, ora o cós, ora a braguilha etc. Por fim, o cliente inconformado reclama, alegando que Deus fizera o mundo em seis dias - o mundo! - não havendo justificativa para o alfaiate levar três meses para fazer as suas calças. "Mas Milord, Milord, - responde o alfaiate - olhe... (gesto de deprezo, com repugnância) ...o mundo... (pausa) ...e olhe... (gesto carinho, com orgulho) ...minhas CALÇAS!"144. Mundo, calças; platéia, peça; aquém e além são dois infernos espelhados.

"Além é... o outro inferno"145, setencia Hamm.

Se o palco é o inferno localizado no aquém, pode-se conjecturar que os personagens estejam mortos ${ }^{146}$. Hamm, de fato, se refere a seus pais como 'pobres mortos', e fala de sua vida como algo que perdura mesmo após a morte:

Clov: [...] Você acredita na vida depois da morte?

Hamm: A minha sempre foi. ${ }^{147}$

\footnotetext{
${ }^{144}$ FP; p.66-7.

${ }^{145}$ FP; p.71.

${ }^{146}$ A solicitação de Hamm por seu caixão, corrobora esta idéia. (FP, p.139)

${ }^{147}$ FP; p. 104.
} 
Contudo, se além do palco é também inferno, está morta inclusive a platéia e os valores do mundo que ela representa.

Estar morto parece ser, no âmbito do texto, viver impermeável à dor do outro. A perplexidade ao mesmo tempo cínica e patética de Hamm, que afirma não saber o que aconteceu, que acredita que tudo eclodiu na sua ausência, esta irresponsabilidade diante da catástrofe, que se abstém diante daquilo que não entende, diante daquilo de que desconhece a causa ${ }^{148}$ (mas cujo efeito é patente), indica a morte da comiseração e sua sede, o coração:

Hamm: [...] Esta noite eu vi dentro do meu peito. Tinha uma ferida imensa.

Clov: Bah! O que você viu foi seu coração.

Hamm: Não, estava vivo. ${ }^{149}$

Pode-se dizer que Fim de Partida pratica uma categoria mimética que registra os estados terminais da palavra ${ }^{150}$ e da empatia. Com o esgotamento de ambos, deve-se esperar que também a história e a História acabem. Contudo, não é o que acontece. Depois de afligir seus ascendentes, reportando o esgotamento das provisões - diante do qual o finamento seria um alívio -, Clov anuncia, como um anjo torto, a possível perpetuação da indigência:

Clov aproxima a escada da janela, sobe, direciona a luneta. Pausa.

148

Hamm: Ausente, sempre. Tudo aconteceu sem mim. Não sei o que aconteceu... (FP, pp.134-5)

${ }^{149}$ FP, p.80.

150 Segundo Angel-Perez, "a desqualificação da linguagem, [como Adorno entendera na Dialética do Esclarecimento], constitui a pedra angular do sistema linguítisco beckettiano." (Angel-Perez, Élisabeth; opus cit. p.40) 
Clov: Ai, ai, ai!

Hamm: É uma folha? Uma flor? Um toma... (boceja) ...te?

Clov: (olhando) Tomate coisíssima nenhuma! Uma pessoa! É alguém!

$[\ldots]$

Clov: [...] Parece uma criança ${ }^{151}$.

Esta criança sinistra ${ }^{152}$, perdida no ermo fora do abrigo, ensimesmada, contemplando talvez o próprio umbigo, ou, mais ameaçadoramente, o próprio sexo, frustra a esperança do repouso final. Se o fim está no começo - como foi visto acima - há o perigo maior de que o começo esteja no fim ${ }^{153}$. O anúncio desta 'complicação' ao final da peça enfraquece o gesto do cair do pano. A despeito de todos os indícios, o fantasma, não da renovação, mas da perpetuação do esgotamento, em configurações cada vez mais desastrosas ${ }^{154}$, assombra esta fábula infernal. De um inferno incomodamente compartilhado aquém e além.

${ }^{151}$ FP, p. 140.

${ }^{152}$ Esta criança evoca (ao modo dos fantasmas) a criança descrita no romance de Hamm.

${ }^{153}$ Cf. Gontarski, S.E.; opus cit., p.46.

154 "...as peças de Beckett têm uma estrutura cíclica, que podem ser melhor descritas como uma espiral decrescente", propõe Michael Worton (Worton, Michael; opus cit., p.69) 


\section{A Criança dividida em muitas}

O proclamado 'romance' de Hamm - que é enunciado no processo mesmo de sua feitura - assoma à peça de modo a intensificar-lhe a tensão. Mantido em suspense até o final, o espectador, por força de pistas contrárias, é confundido, na situação dramática, quanto à capacidade de Clov deixar o abrigo. Do mesmo modo, na situação narrativa, o romance cria suspense quanto à capacidade de Hamm em ser magnânimo. A narrativa vem auxiliar, portanto, a tensão dramática ${ }^{155}$ (sempre insuficiente, se tomado por parâmetro o drama tradicional).

Como Clov não quer ouvir a história, Hamm suborna Nagg, com a promessa de um caramelo, para ter sua mínima audiência. É a audiência que autoriza o discurso. Hamm começa a narrar, então, seu romance já em andamento (“Onde é que eu estava?"156), romance, na verdade, próximo do desfecho ("Essa história não dura muito mais"157). Numa véspera de Natal, fria, ventosa, seca, em que o sol, esplêndido ${ }^{158}$, mergulhava entre os mortos conta Hamm -, chega em sua propriedade um moribundo rastejando. "Vamos,

\footnotetext{
${ }^{155}$ Bruno Clément salienta a importância da narrativa no drama beckettiano, ao afirmar que "o gênio de Samuel Beckett não é nem essencialmente dramático, nem fundamentalmente narrativo: ele consiste em fazer da cena o lugar onde se desenrola o drama da narração...". (Clément, Bruno; opus cit., p.331)

${ }^{156}$ FP, p. 106.

${ }^{157}$ FP, p. 108.

158 "As pertubações climáticas são as marcas, na narração, da desordem instalada em cena; mas são também os signos forjados de uma temporalidade [...]. A meteorologia é sem dúvida a derrisão da cronologia..." (Clément, Bruno; opus cit., p.270)
} 
vamos, apresenta tua súplica", incita o narrador. O homem alude a uma criança, seu filho, abandonada inconsciente em um rincão distante ("dez horas a cavalo") e devastado (sem mais "nem um pecador"), e pede pão para levar até ela. A reação de Hamm exprime o que se pode chamar de 'compaixão às avessas'. Num primeiro momento, tenta esclarecer o suplicante quanto à malignidade de prolongar a vida de seu filho, destinada como a de todos sobre a terra, à extenuação ${ }^{159}$ :

\begin{abstract}
Hamm: Eu dou um pouco de cevada, um quilo, um quilo e meio, você leva para o seu menino, faz, caso ele ainda esteja vivo, uma panela de papa. (...), uma panela e meia, bem nutritiva. Tudo bem. O menino fica corado novamente, pode ser. E depois? (Pausa) Perdi a paciência. Use a cabeça, pense bem, você está [sobre a terra], não tem remédio! $!^{160}$
\end{abstract}

Em seguida, propõe ao outro um emprego (afinal, ele "não teria mais muito tempo neste mundo"), testando, com indisfarçável regozijo, seu afeto paterno:

Hamm: [...] Ainda posso vê-lo de joelhos, as mãos apoiadas no chão, me olhando fixamente com os olhos dementes, apesar da minha proposta. ${ }^{161}$

O homem pergunta, finalmente, se Hamm consentiria em recolher também a criança. E aqui, em seu clímax, a história é interrompida. Alguns detalhes, porém, são fornecidos mais adiante, numa conversa com Clov. Que o emprego

159

Hamm [ao moribundo]: Mas qual é a sua esperança afinal? Que a terra renasça com a primavera? Que os peixes voltem aos mares e rios? Que ainda haja maná no céu para os imbecis como você? (FP, p.108)

${ }^{160}$ FP, p. 107.
${ }^{161}$ FP, p. 108. 
oferecido ao pedinte era ironicamente o de jardineiro (afinal, a história se passa num mundo cuja natureza já está em extinção). Que o menino era bem pequeno e poderia 'fazer todo o tipo de trabalho leve'. Que aquele que vinha "rastejando pelo chão" era "mais um", o que sugere um quadro de carestia geral - um mundo percorrido por seres agonizantes - e dentro dele um privilegiado Hamm, proprietário de alguma provisão.

O romance, supostamente ficcional, guarda, porém, com o presente e o passado dos personagens semelhanças inegáveis ${ }^{162}$ : a derrocada de tudo e a crueldade de Hamm diante dos necessitados. Mesmo a história pessoal de Clov poderia dar seqüência ao romance. Afinal, segundo consta, Clov era pequeno quando chegou até Hamm e não se lembra de seu pai verdadeiro; além disto, como agregado, fez sempre toda espécie de 'serviços leves'. Clov, portanto, poderia ser aquela criança do romance, recolhida por Hamm. Nada, no entanto, garante cabalmente que assim seja. Quando Hamm dá por encerrada sua narrativa, ao final da peça, não se tem certeza do que aconteceu. Na verdade, a história não avança em relação ao que já tinha sido narrado.

\footnotetext{
Hamm: Se ele [poderia] trazer a criança junto... (Pausa) Era o momento que eu esperava. (Pausa) Você não quer abandoná-[la]? Quer que [ela] cresça enquanto você encolhe? (Pausa) Que torne mais suaves seus cem mil derradeiros instantes? (Pausa) [Ela] não
}

\footnotetext{
162 Como nota Clément, o romance não apenas se assemelha a ação dramática, mas acaba por coincidir com ela. "A narração de Hamm, em Fim de Partida, representa em toda a sua complexidade, a única narração beckettiana, [...], perfeita. O tempo aqui é efetivamente aquele do mito, da fábula antiga (o passado), mas ele acaba por reunir-se, mesmo a coincidir com o tempo da ação". (Clément, Bruno; opus cit., p.227)
} 
faz a menor idéia, só sabe o que é a fome, o frio e a morte como chave de outro. Mas você! Você deveria saber o que é o mundo nos dias de hoje. (Pausa) Ah, fiz com que encarasse os fatos, suas responsabilidades! (Pausa. Voz normal) Pronto, aí está, aqui estou, aqui estamos, já chega. ${ }^{163}$

Talvez o pai tenha aceitado mesmo o serviço de jardineiro e abandonado a criança. Talvez, no entanto, tenha seguido adiante, na esperança de encontrar ajuda em outra parte. Talvez tenha voltado para junto da criança. Quem sabe tenha simplesmente morrido antes de qualquer reação. Ou tenha insistido ainda em buscá-la, a ponto de Hamm comover-se e reconsiderar seu ponto de vista. A profusão de hipóteses torna o final inconcludente. Se, por um lado, o quadro de hecatombe e a crueldade de Hamm - expostos na situação narrativa - está refletido no presente dramático; por outro lado, não se tem certeza da relação entre a criança e Clov.

O que se pode dizer é que o romance busca reproduzir o padrão da relação entre salvadores e supliciados, cuja escala iniciada por Deus-pai, passa de geração em geração ${ }^{164}$. Deus-pai, evocado na peça por Hamm ("Rezemos ao senhor"165), revela-se uma fraude: "O porco! Ele não existe!"166. Nagg, por sua vez, não existe como pai. Diz ele a Hamm:

\footnotetext{
Nagg: [...] Quando era um menininho e tinha medo no meio da noite, quem você chamava? Sua mãe? Não. Eu. Deixávamos você berrar. Até trancávamos a porta para poder dormir. (Pausa) Eu estava

${ }^{163}$ FP, p. 147.

${ }^{164}$ Num registro mais psicológico, Morrison analisa, o modo como uma geração, supliciada, suplicia a próxima. (Morrison, Kristin; opus cit., pp.31-2)

${ }^{165}$ FP, p. 109.

${ }^{166}$ FP, p. 110 .
} 
dormindo, feliz, como um rei, e você me acordava para escutá-lo. Não era indispensável, não precisava de verdade que eu escutasse. Além disso, eu não o escutei mesmo. ${ }^{167}$

E Hamm, no papel de pai e salvador, mostra-se um fiasco ${ }^{168}$. Ignorou as súplicas de seu filho adotivo, Clov, por uma bicicleta:

Clov: Quando ainda havia bicicletas, chorei para ganhar uma. Implorei a seus pés. Você me mandou passear ${ }^{169}$.

Recusou óleo para a lamparina de Mãe Pegg ${ }^{170}$, que morreu de escuridão. Dispersou os desesperados que podia ter ajudado, mandando-os de volta às $\operatorname{orgias}^{171}$ :

Hamm: [...] Todos aqueles que eu poderia ter ajudado. (Pausa) Ajudar! (Pausa) Salvar. (Pausa) Salvar! (Pausa) Apareciam por todos os lados. (Pausa. Com violência) Usem a cabeça, pensem bem, vocês estão [sobre a terra], não tem remédio. (Pausa) Partam! Amem-se! Lambam-se uns aos outros! (Pausa. Mais calmo) Quando não era pão, eram brioches. (Pausa. Com violência) Sumam da minha frente, voltem às orgias! $[\ldots]^{172}$

E, quando aparentemente é magnânimo, no romance, oferecendo ao homem ajoelhado a seus pés um emprego, sua intenção é, pelo contrário, restituir a

${ }^{167}$ FP, p.111.

${ }^{168}$ Assim como Godot, que é um salvador ineficiente para Didi e Gogo, "Hamm - segundo Morrison - é um deus falho de um mundo 'cadavérico', parodiando o papel tradicional da divindade de várias maneiras". (Morrison, Kristin, opus cit., p.33)

${ }^{169}$ FP, p.47.

${ }^{170}$ A metáfora luz/vida e escuridão/morte é evidente.

${ }^{171}$ Hamm culpa os suplicantes por sua própria miséria, e remete-os de volta à causa de todo 0 sofrimento: cópula e procriação. Quando chama seu pai de 'maldito fornicador', Hamm culpa-o por ser causa de sua existência e conseqüentemente de seu sofrimento.

${ }^{172}$ FP, p. 128. 
ordem perversa de um mundo em que pais ignoram os filhos, em que possíveis servadores são indiferentes à indigência alheia. Se consegue corromper o zelo ‘inadequado’ daquele homem, isso não se sabe.

Correspondente às memórias pessoais, o romance ${ }^{173}$ constitui a história de um impasse ${ }^{174}$, de um instante intransponível que exila Hamm de um devir. Fim de Partida, à luz deste exílio, revelaria os traços de um monodrama (ou drama da mente). Outros fatores na peça contribuem para esta hipótese:

- "Mais de um comentador notou a possível analogia da configuração do palco em Fin com a representação alegórica do interior de um crânio, com janelas no lugar de olhos[... ${ }^{175}$.

- A iterada menção à sua dor de cabeça, que lateja como um coração, que tortura como uma goteira ('desde os tempos da moleira'), vem confirmar a cabeça de Hamm como foco fundamental desta obra. A cabeça, notadamente em seu aspecto palratório, é o que vigora ainda neste corpo paralítico e com olhos cegos.

- A reivindicação de Hamm pelo lugar central no palco, reforça seu papel de orquestrador da história ou histórias.

\footnotetext{
${ }^{173} \mathrm{O}$ procedimento narrativo de Hamm, que confunde romance e memória pessoal, é próximo àquele de Malone. "Reprimidas - diz Souza Andrade a respeito de Malone -, as lembranças vão se insinuando, primeiro sorrateiramente, agentes provocadores, depois arregimentadas em milícias numerosas, tomando conta das rédeas da narrativa, fundindo as histórias à memória". (Andrade, Fábio de Souza; opus cit.; p.119)

${ }^{174}$ Como se Hamm - seu discurso - orbitasse um ponto-cego, uma memória-tabu, que não pode ser enfrentada.

${ }^{175}$ Idem, ibidem, p.84.
} 
- Citando Shakespeare, "Our revels now are ended"176, Hamm parodia Próspero. O mago dispensa, com esta frase, os espíritos que evocara para encenar suas fantasias. Hamm, com as mesmas palavras, dispensa seu pai - ou, dir-se-ia, o espírito deste -, que não ganhará mais a cena. Lembre-se ainda que é neste mesmo ato IV de A Tempestade, que se ouve o tão repetido apotegma "somos feitos da mesma matéria de nossos sonhos" ${ }^{\text {"177; }}$ que, por contágio, reiteraria o caráter onírico dos personagens.

- A falta de autonomia de Clov em relação a Hamm, permite entendê-lo como personagem daquele. O próprio Clov se surpreende com sua subserviência: "Faça isso, faça aquilo, e eu faço. Nunca me nego. Por quê?"178. E quando indaga sobre sua condição existencial - "Pra que eu sirvo?" -, a resposta de Hamm é inequívoca: "Para me dar as deixas"179. Se está fora de cena, Clov jaz em sua cozinha, rente à mesa e de frente para a parede, como um objeto a espera de uso. As rubricas que prescrevem seus dois monólogos ("olhar fixo, voz neutra"), pintam-no como um autômato. Hamm só desiste de Clov e o dispensa ("Acabou, Clov, acabamos. Não preciso mais de você" ${ }^{180}$ ), quando, preocupado em encontrar mais personagens para sua história, é alertado da presença da criança fora do abrigo. Um novo personagem dispensaria o antigo.

\footnotetext{
176 "Fim da folia”, em português. "Finie la rigolade", em francês. "Das Fest ist jetzt zu Ende", em alemão.

177 "We are such stuff as dreams are made of'. Shakespeare, The Tempest, IV, cena 1.

178 "Clov: Há uma coisa que não consigo entender. (...) Por que obedeço sempre? Pode me explicar isso?" (FP, p.137)

${ }^{179}$ FP, p.114.

${ }^{180}$ FP, p. 143 .
} 
- "Longe de mim é a morte"181, declara Hamm, supondo-se centro irradiador de vida, ou, dir-se-ia, de efabulação. A frase é um aviso sobre as consequências da partida de Clov. O vínculo ficcional que prende Clov a Hamm explicaria também a perplexidade com que é encaminhado para o fim: "Bom, isso nunca acabará, nunca vou partir. (Pausa) E então, um dia, de reprente, acaba, muda, não entendo nada, morre, ou morro eu, também não entendo"182. O personagem é manipulável, para vida ou para a morte, sujeito à extravagância de seu autor.

- A migração de temas ou frases de um personagem para outro, indicaria a sujeição destes a um agente comum. "Por que esta comédia, todos os dias?"183, diz Nell e, mais tarde, Clov. Clov e Hamm referem-se ao paradoxo do monte. "Os grãos se acumulam, um a um, e um dia, de repente, lá está um monte, um amontoado, o monte impossível”184, explica Clov. E Hamm: "Momento sobre momento, pluf, pluf, como os grãos de milho miúdo de... (hesita) ...daquele velho Grego, e passa-se a vida esperando que disso resulte uma vida"185. O modo como Clov veste-se para partir ("Panamá, paletó, sobretudo sob o braço, guardachuva, mala"186), externa um fascínio pelas variações metereológicas, similar ao demonstrado por Hamm enquanto romancista.

\footnotetext{
${ }^{181}$ FP, p. 130.

${ }^{182}$ FP, p.145-6.

${ }^{183}$ FP, p.57 e p.80.

${ }^{184}$ FP, p.38.

${ }^{185}$ FP, p. 129.

${ }^{186}$ FP, p. 147.
} 
Todavia, o dado mais contundente a corroborar a tese do monodrama nasce da análise do solilóquio de Hamm, notadamente o segundo deles, o qual além de conter a estrutura da peça inteira, confere explicitamente a Hamm o papel de dramaturgo: ele não apenas é autor do romance, mas, paradoxalmente, autor da própria peça em que atua.

Depois de descortinar o cenário (janelas e latões) e Hamm, Clov volta-se para o público e prefacia a peça, como porta-voz do autor ${ }^{187}$, estabelecendo para a audiência a qualidade deste jogo: um jogo que começa perto do fim ("Acabou, está acabado, quase acabando, deve estar quase acabando"188). Então, com o primeiro solilóquio de Hamm ("Minha vez. De jogar"”189), tem início a partida propriamente dita, definida de entrada como "hesitação em ter um fim".

O terceiro solilóquio, com o qual a peça se encerra, retoma o mesmo mote: "Minha vez. De jogar"190. Desta vez, no entanto, Hamm vai "acabar de perder", depois de hora e meia de 'hesitação'. Ele descarta seu croque (inútil desde o princípio, pois não serve como apoio para mover sua cadeira de rodas), descarta seu cão de pelúcia (inútil como sucedâneo de suplicantes reais), e seu apito (inútil para chamar Clov, seu contato com o mundo fora do abrigo, que foi dispensado). Ele retoma seu romance, mas não avança além do impasse já citado; recita Baudelaire, assinando com os versos do poeta o

\footnotetext{
${ }^{187}$ Autor, neste sentido, é Hamm. Beckett fica estrategicamente invisível sob a atuação de seus personagens autores.

${ }^{188}$ FP, p.38.

${ }^{189}$ FP, p.39.

${ }^{190}$ FP, pp.146-7.
} 
encerro do jogo ("Clamaste pela escuridão, a noite escura caiu"); acata a qualidade nula dos momentos desta partida, que fecham a história sem construir um sentido de conjunto ("Momentos nulos, nulos desde sempre, mas que são a conta, fazem a conta e fecham a história"); e cobre, por fim, a boca com seu velho trapo, interrompendo a fala, ao que parece, por falta de ouvintes $^{191}$. Clov, vestido para partir, está, porém, em cena, e uma criança espreita além do abrigo. O fim advém sob a sombra de um recomeço. Resta ainda que silenciosa - uma audiência possível.

A análise do segundo solilóquio ${ }^{192}$ sustenta, como se disse, a tese monodramática. Aqui, Hamm recapitula em frases-chave todo o enredo até o momento da enunciação do solilóquio. Contudo, quebrando a lógica temporal, Hamm extrapola as fronteiras do presente, e antecipa o final da peça ao modo das profecias. Arrolar estas frases-chave e deter-se nelas, permite compreender, além da estrutura monodramática do texto, o tratamento que Beckett confere às figuras de confinamento e circularidade em Fim de Partida. Segue-se a análise, frase a frase.

\section{1. “[Minha vez]".}

No lugar de "Minha vez. De jogar", como lemos no segundo e terceiro solilóquios, Beckett emprega desta feita a abreviação "Minha vez", e, de entrada, marca o caráter sintético de todo o parágrafo. ${ }^{193}$

\footnotetext{
${ }^{191}$ Como explica Worton: "Sem ouvintes (neste caso, Clov) a única alternativa é 'não falar mais"'. Worton, Michael, opus cit., p. 74)

${ }^{192}$ FP, pp.128-9. Localizado no último terço da peça.

${ }^{193}$ Em francês se lê a forma contracta "À mol", em inglês, contudo, mantém-se o "Me to play", pois não é possível forma mais sintética.
} 


\section{2. "Estamos progredindo".}

Repete-se o bordão que recapitula o truncado andamento da peça.

3. "A gente chora, chora, por nada, para não rir, e [pouco a pouco] vai se sentindo triste de verdade".

O choro entra em cena gradativamente. Primeiramente, Nell tenta chorar; depois, Hamm fala com a voz embargada ao saber que não há mais calmantes; e, por fim, Nagg chora, manifestando, com isso, seu estatuto existencial: choro, logo existo. Há também aqui referência ao paradoxo do monte. De grão em grão, ou melhor, de choro simulado em choro simulado, chega-se, apesar de aparentemente impossível, ao monte, ou melhor, à verdadeira tristeza.

4. "Todos aqueles que eu poderia ter ajudado. Salvar. Salvar! Apareciam de todos os lados. Usem a cabeça, pensem bem, vocês estão [sobre a terra], não tem remédio. Partam! Amem-se! Lambam-se uns aos outros! Quando não era pão, eram brioches. Sumam da minha frente, voltem às orgias! Isso tudo! Isso tudo!" Com esta passagem, comprova-se a ligação entre o passado de Hamm e o romance. Recapitula-se, assim, a indiferença de Hamm diante dos necessitados.

5. "Nem mesmo um cão de verdade".

Referência ao cão de pelúcia que Clov confecciona para Hamm. Mas também referência ao próprio Clov que é, em duas passagens, chamado de cão. Quando entra em cena com o lulu, Clov diz para Hamm: "Aqui estão seus cães"194. E, no primeiro solilóquio, Hamm diz: "Pode haver miséria mais sublime do que a minha? Sem dúvida. Naquele tempo. Mas e hoje? Meu pai? Minha mãe? Meu... cão ${ }^{195 "}$ Note-se que a hesitação em dizer

\footnotetext{
${ }^{194}$ FP, p.91.

${ }^{195}$ FP, p.39.
} 
'cão', neste primeiro solilóquio, é estruturalmente idêntica àquela em dizer 'filho' ('Terei chamado meu pai e terei chamado meu... (hesita) ...meu filho"), que se lerá mais adiante, no segundo solilóquio. Ao confundir-se com o cão de pelúcia, 'que não é de verdade', Clov expõe-se como artefato e fantasia (de Hamm).

6. "O fim está no começo e no entanto continua-se".

A peça, iniciada pelo fim ("Acabou, está acabado..."), prossegue apesar disso, uma vez que Hamm hesita em ter um fim.

7. “Talvez pudesse continuar minha história, dar um fim e começar outra”.

Pequena variação em relação ao final da narração de Hamm. Naquela, Hamm pressente que o fim da história poderia ser postergado com a criação de novos personagens. Aqui, pensa-se na possibilidade de prosseguir, no entanto, com uma história nova. Nos dois casos, porém, acentua-se a dificuldade em silenciar.

8. "Talvez pudesse me atirar no chão. Cravar as unhas nos vãos e me arrastar adiante, com a força dos pulsos. Será o fim então e me perguntarei por que chegou o fim, por qual... (hesita) ... por que motivo demorou tanto.

Retoma-se aqui o anelo, impossível de cumprir-se, de suicidar-se, exposto anteriormente com a seguinte passagem: "Se eu pudesse me arrastar até o mar! Eu faria um travesseiro de areia e a maré viria”"196.

As frases do solilóquio arroladas acima remontam sinteticamente as idéias-chave da peça expostas até este momento. A partir de agora, no entanto, o solilóquio descreverá, também sinteticamente, a continuação da peça. Hamm adianta, resumidamente, o que se estenderá nas páginas

${ }^{196}$ FP, p. 119 . 
seguintes até o final. Sua capacidade profética fortalece a tese do monodrama. O segundo solilóquio revelaria Hamm como irradiador da peça, mas de uma maneira peculiar: ele está contido na própria peça que inventa. A imagem escheriana do jovem na galeria de arte aplica-se também a Fim de Partida. Mas Hamm inventa a peça estando dentro da peça. Assim, pode-se afirmar que ele é prisioneiro de sua própria fantasia. Segue-se a análise da segunda metade do solilóquio.

9. “Lá estarei eu, no velho refúgio, sozinho contra o silêncio e... (hesita) ...a inércia. Se puder me calar e ficar em paz, estará acabado, todo som, todo o movimento". Sem poder arrastar-se por terra e finar, Hamm também não poderá terminar sua história ${ }^{197}$. Assim, estará no abrigo em desassossego (não ficará em paz nem em silêncio).

10. "Terei chamado meu pai e terei chamado meu... (hesita) ...meu filho. Até duas, três vezes, se não me ouvirem na primeira ou na segunda."

Um pouco antes de encerrar a peça, antes de cobrir-se com o trapo, Hamm chamará, de fato, seu pai (por duas vezes) e Clov (por uma vez).

11. "Direi, Ele vai voltar. E depois? E depois? Ele não pôde, foi longe demais. E depois? Todo tipo de alucinação! Que estão me vigiando! Um rato! Passos! Olhos! Respiração contida e depois... ."

Hamm sofrerá a partida de Clov, seu último ouvinte, e terá medo (conterá a respiração), assim como tinha medo quando era criança e buscava o pai como ouvinte. O medo o induzirá, ao que parece, a alucinações, e sentir-se-

\footnotetext{
${ }^{197}$ Para Jane Alison Hale, "a única maneira que ele [Hamm] pode imaginar um fim para seu efabular é imaginar um fim para sua vida". (Alison Hale; Jane, "Endgame: how are your eyes" in Connor, Steven (editor), opus cit., p. 76)
} 
á vigiado, ouvirá passos. E, de fato, ao final da peça, Clov entrará em cena, e fixará com seu olhar Hamm até o último momento.

12. "Depois falar, depressa, como a criança sozinha que se divide em muitas, duas, três, para ter companhia, conversar com outros, no escuro".

Em situação abismal, escuridão-cegueira-vazio, Hamm pode defender-se, como uma criança amedrontada, desdobrando-se em muitos (em Clov,

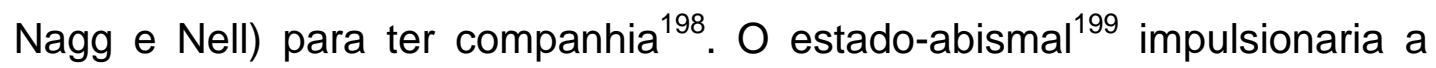
efabulação dramática. Neste caso, a peça não terminaria, mas se repetira, desdobrando-se em novas configurações, pois a falta de ouvinte (a iminente partida de Clov no final) e o escuro (a cegueira) gerariam o desdobramento de si. O fim da peça apontaria para seu recomeço, e assim, o começo da peça, com Clov, Nagg e Nell orbitando em torno de Hamm, seria decorrência imediata do fim. Note-se a situação cíclica. O esgotamento da história produzindo mais história. Hamm está, neste caso, condenado à efabulação.

13. "Momento sobre momento, pluf, pluf, como os grãos de milho [ ] de... (hesita) ...daquele velho Grego, e passa-se a vida esperando que disso resulte uma vida". Hamm adianta aqui a compreensão (exposta no final da peça) de que os momentos que escoam são nulos. A vida não terá um sentido, como atestou já o riso de Clov ("não estamos começando a significar alguma coisa"?). Padecer é sem sentido e a história fecha-se em vão.

14. "[Ah, basta]".

\footnotetext{
${ }^{198}$ Mais tarde, na obra de Beckett, encontrar-se-á este recurso em textos como Improviso de Ohio e Companhia.

${ }^{199}$ Hamm não é, neste caso um personagem solitário, mas um personagem em estado de total desamparo.
} 
A peça terminará. Hamm, de fato, cobrirá o rosto com o trapo. Contudo, a contar com o que se analisou até aqui, o fim do jogo não coincide com o fim da efabulação (dramática ou narrativa). Na situação de Hamm, a efabulação é infinita.

A leitura monodramática, que entende Hamm como um personagem dividido em muitos, não se impõe sobre outras possíveis leituras. O texto beckettiano legitima a presença de várias camadas semânticas. $O$ trabalho hermenêutico deve relevar este fato.

Para entender Fim de Partida como um drama de consciência, drama e consciência devem ser vistos em sua inadequação histórica. Drama como uma forma ultrapassada, inapropriada, mas paradoxalmente resistente; e consciência como o núcleo de um sujeito sem subjetividade, prisioneiro de determinações externas e habituais, sem consistência e imperativos internos, máquina passiva, mas inesgotável.

Existe, no entanto, a possibilidade de conjugar os vários estratos do texto, se se detém sobre questões de ordem formal. As figuras infernais até aqui desenhadas - circularidade, confinamento, inconcludência e paradoxo fazem convergir as muitas leituras da peça - moral, metadramática e filosófica $^{200}$ - num mesmo ponto historicamente determinado: o esgotamento dos valores fundantes de uma civilização, que, apesar disso, não fina.

${ }^{200}$ Leia-se: da impossibilidade da moral, do drama e da filosofia. 


\title{
5. De que se pode falar ainda?
}

Qual o papel do artista num quadro como este? O de Beckett é dividir-se em muitos. No caso de Fim de Partida, dividir-se em dois: em Hamm e no louco. O louco, trazido à memória por Hamm, era pintor. Hamm é efabulador.

\begin{abstract}
Hamm: Conheci um louco que pensava que o fim do mundo tinha chegado. Ele pintava. Eu gostava muito dele. la vê-lo no hospício. Eu o tomava pela mão e o arrastava até a janela. Olhe! Ali! $O$ trigo começa a brotar! E Ali! Olhe! As velas dos pesqueiros! Como é bonito! (Pausa) Ele me fazia soltar sua mão, bruscamente, e voltava para o seu canto. Apavorado. Tinha visto apenas cinzas. (Pausa) Apenas ele tinha sido poupado. (Pausa) Esquecido. (Pausa) Parece que o caso não é... não era... tão... tão raro ${ }^{201}$.
\end{abstract}

A natureza aporética do trabalho do artista é, como expressa Clov, 'terrível'202. Pelas duas janelas do hospício, uma voltada para a terra, outra para o mar, o pintor só vê cinzas. Do mesmo modo no abrigo: as duas janelas, uma voltada para o mar e outra para a terra, revelam uma hecatombe. A loucura reside em pintar, quando não há mais nada o que representar. Ou também se pode perguntar, que tipo de obcecação é essa em narrar, quando não há mais mundo nem sujeito? Entre os parcos objetos do abrigo, vê-se um quadro, com sua face voltada para a parede. Sinal de luto, talvez. Vestígio da ‘endofilia' de Hamm? Resíduo das visitas ao hospício? É possível.

\footnotetext{
201 FP, p.97.

202

Hamm: Eu gostava muito dele. (...) Ele pintava.

Clov: Há tantas coisas terríveis. (FP, p.98)
} 
A remissão, contudo, às artes plásticas faz transparecer a poética beckettiana, traçada pelo autor em "Três Diálogos com Georges Duthuit" que se irmana em alguma medida do 'fazer' de seus personagens. Beckett, nestes diálogos, buscando compreender a especificidade da obra do pintor Bram van Velde, acaba por revelar sua própria perplexidade enquanto autor. 'Artistas das cinzas', poder-se-ia dizer, a respeito daqueles que vivenciam o esgotamento da expressão. Segundo Beckett, van Velde dá as costas às possibilidades expressivas da arte, preferindo "a expressão de que não há nada a expressar, nada com que expressar, nada a partir do que expressar, nenhuma possibilidade de expressar, nenhum desejo de expressar, aliado à obrigação de expressar"204. Este imperativo artístico paradoxal está constelado em Fim de Partida: o exaurimento dos meios aliado a impossibilidade de um fim.

O quadro voltado para a parede epitoma em cena um contra-senso que levou Beckett, durante as conversa com Duthuit, a uma afasia de duas semanas:

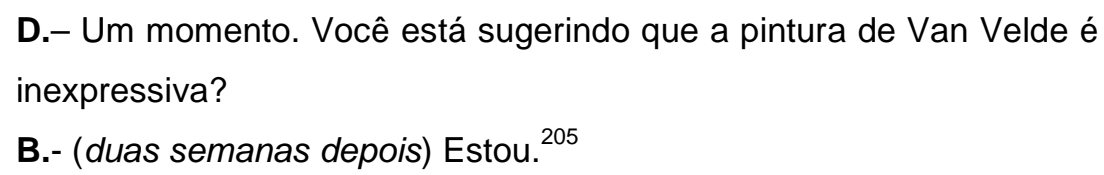

B.- (duas semanas depois) Estou. ${ }^{205}$

203 Beckett; Samuel, "Três diálogos com Georges Duthuit", tradução de Fábio de Souza Andrade, in Andrade, Fábio de Souza, opus cit., pp.174-81.

${ }^{204}$ Idem, ibidem, p.175.

${ }^{205}$ Idem, ibidem, p.175. 
A função do artista é falhar, "o fracasso é o seu mundo"206. Se Beckett falha pensadamente, organizando cinzas ${ }^{207}$, Hamm, que é assolado por uma narrativa insatisfatória, sofre-a de modo aparentemente inconsciente.

Contudo, o que se chamou acima de imperativo artístico paradoxal, a obrigação de prosseguir, sem material e sem porquê, é o traço infernal que submete tanto Beckett quanto a trupe de seus personagens palradores. Todos estão congregados na divisa d'O Inominável: "é preciso continuar, não posso continuar, vou continuar"208.

De que se pode falar ainda? Daquilo que a arte desdenha sempre que se encapsula na preocupação com suas possibilidades expressivas; daquilo que resta quando mundo e subjetividade estão destroçados. Ainda se pode falar - e Beckett o faz, assim como seus personagens - de nada ${ }^{209}$.

\footnotetext{
${ }^{206}$ Idem, ibidem, p.178.

207 Organizar cinzas é a tarefa paradoxal da poética de Beckett, e que Souza Andrade explica assim: "num mundo privado de sentido imanente, a partir de uma sujeito esvaziado da capacidade reflexiva, é preciso elaborar formas significativas, ao mesmo tempo denúncia e cópia deste estado de coisas". (Andrade, Fábio de Souza; opus cit., p.31)

208 Beckett, Samuel; O Inominável, tradução de Waltensir Dutra, Rio de Janeiro: Nova Fronteira, 1989, p.137.

209 'Nothing to express', no orginal, "significa não apenas que não há nada a expressar, mas também que há justamente este nada a ser expresso." Andrade; Fábio de Souza, opus cit., nota 1, p.175.
} 


\title{
III. A Última Fita de Krapp
}

\author{
¿ Intermitência ৯
}

"A little, wearish old man, very melancholy by nature"

Robert Burton, Anatomy of Melancholy

"Trata-se de um registro de ocorrências diversas e mutáveis e de vagas conjecturas, eventualmente contraditórias: seja porque sou outro eu-mesmo, seja porque tomo os assuntos

em outras circunstâncias e por outras considerações"

Michel de Montaigne, Os Ensaios, III, 2

"O hábito é o lastro que acorrenta o cão a seu vômito"

Samuel Beckett,

Proust 
Aos vinte e quatro anos, Krapp desenvolve o hábito de gravar fitas magnéticas nas noites de seu aniversário. Nestas datas, após meditar sobre o ano que passou, e separar - como explica - 'o joio do trigo', procede ao registro de sua crônica pessoal, selecionando apenas os fatos que merecem ser lembrados no futuro ${ }^{210}$. Cada fita magnética deveria conter, portanto, 0 conjunto de resoluções e escolhas, de acontecimentos e vivências, enfim, do artificioso passo a passo de Krapp na direção de seu apogeu. As fitas seriam, ao fim e ao cabo, o conjunto das ocorrências-chave que permitiriam entender causalmente o caminho percorrido até o zênite daquele que espera ver concretizada sua veleidade de escritor em um opus magnum. Caso contrário, o encadeamento dos fatos poder-se-ia perder, privando sua história de um nexo unificador. Aos sessenta e nove anos, porém - e quarenta e cinco fitas magnéticas gravadas ${ }^{211}$ - Krapp sofre uma ruptura no processo habitual. Seu presente - ele percebe - não é o futuro ansiado da juventude; o registro de seu passado não garantiu a unidade de sua história pessoal; o tempo, vivido na dimensão habitual, o iludiu; e a dúvida arruína retrospectivamente suas escolhas e ações. A história de Krapp contada aqui linearmente, é levada ao

\footnotetext{
210 "Sentado diante do fogo com os olhos fechados, separando o joio do trigo. [...] O trigo, o que agora quero dizer com isso, quero dizer... (hesita)... Suponho que queira dizer daquelas coisas que valerão a pena quando toda a poeira - quando toda a minha poeira tiver depositado". As citações de A Última Fita de Krapp são traduzidas por mim, baseadas no texto dos Theatrical
} Notebooks, revisto por James Knowlson e na versão francesa da Minuit. (Knowlson, James (editor); The Theatrical Notebooks of Samuel Beckett - Krapp's Last Tape, Londres: Farber and Farber, 1992)

${ }^{211}$ Como deduz James Knowlson, observando que são nove as caixas com bobinas que Krapp traz para a mesa, "há então logicamente quarenta e cinco fitas gravadas, uma vez que há cinco bobinas em cada caixa. Como cada bobina representa um aniversário, ele [Krapp] começou a gravar - ... - com vinte e quatro anos (sessenta e nove menos quarenta e cinco). (Knowlson, James; opus cit., p.19) 
palco por Beckett, no entanto, de modo concêntrico (e concentrado). O velho Krapp, no dia de seu aniversário, ouve a fita de seu aniversário de trinta e nove anos, nesta fita ele relata ter acabado de ouvir outra fita referente a seu aniversário de vinte e nove anos. O velho Krapp, o Krapp de meia idade e o jovem Krapp são assim apresentados simultaneamente ao público ${ }^{212}$. O efeitomatrioshika empregado por Beckett aqui percorre a peça em várias outras imagens:

- $\quad$ o envelope onde Krapp anota os fatos que deverá gravar;

- sua vestimenta cravada por muitos bolsos;

- as gavetas da escrivaninha que contêm fitas virgens;

- as caixas que armazenam as fitas gravadas;

- as bobinas que envolvem as fitas;

- um livro de registro que descreve de cada fita seus episódios principais;

- as próprias fitas que contêm os relatos;

- os próprios relatos que remetem a relatos passados;

- a escuridão que confina Krapp a um pequeno foco de luz;

- o compartimento iluminado na coxia, mas fechado por uma cortina onde Krapp vai buscar as caixas de fita e o magnetofone -, e que espelha o palco, ao contrastar luz e sombra ${ }^{213}$.

\footnotetext{
${ }^{212}$ Kristin Morrison torna preciso este quadro ao descrevê-lo assim: "Krapp-sobre-o-palco-comsessenta-e-nove; Krapp-na-fita-aos-trinta-e-nove; Krapp-na-fita-aos-vinte-e-nove-como-citadopor-Krapp-na-fita-aos-trinta-e-nove". (Morrison, Kristin; Canters and Chronicles - The Use of Narrative in the Plays of Samuel Beckett and Harold Pinter, Chicago, Londres: The University of Chicago Pres, 1995, p.54)

${ }^{213}$ Foi no Schiller Theater em Berlim (1969), quando dirigiu A Última Fita de Krapp, que Beckett introduziu este recesso na montagem (cubby-hole, em inglês; cagibi, em francês),
} 
Todas estas imagens traduzem a impossibilidade do registro magnético preservar definitiva e inabalavelmente um certo momento. Como explica Steven Connor, "cada relato pode ser tomado ou envelopado por uma outra circunstância, por um outro contexto de entendimento. Assim, a vida de Krapp gravada é menos uma série logicamente contínua de declarações distintas, cada uma localizada firmemente em seu contexto intencional, do que uma rede de envelopamentos mútuos, de momentos auto-referentes, cada um deles infinitamente deslocado de seu contexto original, e regrafado num outro lugar"214. Tais deslocamentos são responsáveis pela impossibilidade de Krapp se indentificar com seus 'eus' passados, fato que será analisado mais adiante.

Todas estas imagens afinam-se visualmente também com 0 'enclausuramento' de Krapp nos registros habitual e passional. No registro passional, fica-se sabendo, que, apesar da reiterada intenção de mudança, Krapp, ano após ano, mostra-se impotente diante de seus três vícios: a queda pelo álcool; o desejo por bananas (que Ihe provoca constipação); e a necessidade de sexo. No registro habitual, Krapp está preso à sua rotina, sobretudo a que reza gravar fitas em noites de aniversário.

novidade que manteve em todas as outras produções em que esteve envolvido. (Cf. Knowlson, James; opus cit. p.12)

${ }^{214}$ Connor, Steven; Samuel Beckett - Repetition, Theory And Text, Oxford: Basil Blackwell, 1988, p.130. 
A Última Fita de Krapp dialoga com a mecânica do hábito explorada por Beckett em seu ensaio sobre Proust ${ }^{215}$, em que discorre sobre as memórias voluntária e involuntária. Neste ensaio Beckett pondera as considerações de Proust a respeito do "trabalho do hábito sobre a memória, e as suas conseqüências para a experiência subjetiva do Tempo"216. Sob efeito do Tempo, o indivíduo nunca é um, mas vários: "não estamos meramente mais cansados por causa de ontem, somos outros"217. Assim, a possibilidade de realização (satisfação de um desejo) é praticamente impossível. Aquilo que desejei no momento $A$, não posso satisfazer no momento $B$, uma vez que já não sou mais o mesmo de antes. O hábito, contudo, pode garantir uma espécie de unidade, renovando permanentemente o pacto entre os diferentes sujeitos que eu sou e assim proteger-me do sofrimento, angústia e risco destas 'transubstanciações'. "O hábito, então, é um termo genérico para os incontáveis compromissos travados entre os incontáveis sujeitos que constituem o indivíduo e seus incontáveis objetos correspondentes"218, explica Beckett. A memória de um homem com hábito eficiente é uma memória uniforme, "um instrumento de referência e não de descoberta. (...) Sua memória é um varal e as imagens de seu passado são roupa suja redimida, [são] criados infalivelmente complacentes de suas necessidades de reminiscência"219. Esta é - na visão de Proust - a memória voluntária: menos do que uma memória, tratase de uma "simples consulta no índice remissivo do Velho Testamento do

\footnotetext{
${ }^{215}$ Beckett, Samuel; Proust, tradução de Arthur Nestrovski, São Paulo, Cosac \& Naify, 2003.

${ }^{216}$ Cf. Wood, Rupert; "An endgame of aesthetics: Beckett as essayist" in Pilling, Joe (editor), The Cambridge Companion to Beckett, Cambridge: Cambridge University Press, 1993, p.4.

${ }^{217}$ Beckett, Samuel; opus cit., p.11.

${ }^{218}$ Idem, ibidem, pp.17-18.

${ }^{219}$ Idem, ibidem, pp.29-30.
} 
indivíduo"220. Krapp e suas fitas magnéticas, organizadas em caixas, ordenadas em um livro de registro fácil de consultar, parecem ilustrar este mecanismo, qualificado por Beckett como mecanismo incondicionalmente 'democrata', uma vez que "não faz qualquer distinção entre os Pensamentos de Pascal e uma propaganda de saponáceo"221. E, de fato, o livro de registro de Krapp lista indiferentemente, uns depois dos outros, fatos tão distintos como a morte da mãe e sua condição intestinal ${ }^{222}$. Além disso, "a memória voluntária - explica Beckett - insiste na mais necessária, salutar e monótona forma de plágio - o plágio de si mesmo"223. Krapp, ao buscar a unidade de si pelo registro magnético de suas memórias, é plagiador compulsivo, forjando-se ficticiamente (pois seletivamente) uma história. A memória, propriamente dita, não obstante, é a memória involuntária. Esta tange, para Proust, a experiência mística, e sustenta a composição de sua obra. A memória involuntária irrompe independentemente da vontade, libera da familiaridade do mundo, e permite acesso ao encanto do real. Como diz Beckett: "quando o objeto é percebido como particular e único e não como simples membro de uma família, quando ele aparece independente de qualquer noção geral e desligado da sanidade de uma causa, isolado e inexplicável à luz da ignorância, então e somente então poderá ser uma fonte de encantamento"224. Contudo, se algo como a memória involuntária assoma à Krapp, isto não vem para proporcionar encantamento, mas para fazer suspeitar. Distintamente do universo proustiano, a memória

\footnotetext{
${ }^{220}$ Idem, ibidem, p. 31.

${ }^{221}$ Idem, ibidem, p. 32.

${ }^{222}$ A reiterada escatologia do texto faz ressonância ao próprio nome do personagem, Krapp (crap), excremento. O deleite com que Krapp pronuncia várias vezes ao início da peça a palavra spool (bobina), parece derivar da assonância entre spool e stool (fezes).

${ }^{223}$ Idem, ibidem, p. 32.

${ }^{224}$ Idem, ibidem, p.22.
} 
involuntária em A Última fita de Krapp não remete a um eu ou essência irredutíveis, ela simplesmente desestabiliza a mecânica de uma vida, por trás da qual não existe mais nada.

Diferentemente do Krapp com trinta e nove anos, que relata ter escolhido aleatoriamente uma fita para ouvir antes de iniciar a descrição de seu ano passado, o velho Krapp, antes de gravar sua crônica de aniversário, procura de modo intencional no livro de registro uma fita específica: "caixa três, bobina cinco". A idéia the ocorre logo ao início da peça, durante a pantomima de abertura, no momento em que contempla o vazio a sua frente com a ponta de uma banana enfiada na boca. A banana, derrisão talvez da madeleine proustiana, é abandonada e cede espaço a outros objetos cênicos: o livro de registro, as caixas com as bobinas de fitas e o magnetofone. Como dois olhos hipnotizantes, as bobinas girarão no aparelho durante toda a peça, traduzindo em imagem as órbitas que Krapp repetirá em torno do vazio. Vazio e silêncio 225 são a matéria destilada de sua vida:

- dos vinte e nove anos, remanesce um quadro que sugere separação ("uma moça num casaco verde surrado, na plataforma da estação");

- aos trinta e nove comemora o aniversário na taverna deserta, a voz cantante de miss McGlome (sua vizinha talvez) silencia, perde a mãe, diz adeus ao amor, é-lhe revelada epifanicamente a escuridão como

\footnotetext{
${ }^{225}$ Não se pode ignorar a possibilidade de que o humor beckettiano faça do silêncio e vazio, que circundam Krapp, consequência de sua mencionada surdez e miopia.
} 
elemento a ser abraçado doravante (ao que parece, para a realização de sua obra literária) ${ }^{226}$;

- aos sessenta e nove anos, a escuridão almejada o circunda, mas ameaçadoramente, e, desfeitos todos os laços externos, resta-lhe revolver os fantasmas da memória e reviver fantasias românticas.

Krapp velho chora relendo Effi Briest (heroína de Theodor Fontane) e no escuro do quarto reencena estar novamente no vale numa véspera de Natal juntando azevinho, reencena estar novamente em Croghan numa manhã de domingo ouvindo os sinos junto com sua cachorra. "Estar novamente, estar novamente. Toda esta velha miséria. Uma vez não foi suficiente para você", remorde-se. Ao modo das bobinas que rodam sobre si mesmas, Krapp circula como um prisioneiro no pátio estreito da memória, e regrava, ano após ano, uma mesma história, que, curiosamente, nunca reconhece como sua.

O paradoxo reside na impossível sincronização de tempos diferentes. Aos trinta e nove anos, Krapp escarnece do Krapp de vinte e nove anos: "Difícil acreditar que eu tenha sido um dia este fedelho". E aos sessenta e nove, demonstra o mesmo estranhamento em relação ao Krapp de trinta e nove: "Acabo de ouvir este bastardo idiota por quem me tomava há trinta anos atrás, difícil acreditar que um dia eu tenha sido tão medíocre assim". A tentativa de dar unidade à sua história pela manutenção e ordenação das memórias na fita,

\footnotetext{
${ }^{226}$ A aqui chamada epifania de Krapp não aparece no texto de modo explícito, Beckett lança mão de um recurso retórico que consiste em interromper uma frase no meio, deixando ao público a tarefa de completá-la. Uma análise consistente deste procedimento e do teor do 'insight' de Krapp é realizada por Kristin Morrison em livro supracitado. (Morrison, Kristin; opus cit. pp.60-1)
} 
não resiste, porém, à metamorfose operada pelo tempo. A aparente imparcialidade dos registros mecânicos é traída a cada audição. Só o fato de cindir-se em sujeito e objeto já é motivo de alienação. O plano epistêmico (em que ocorre a ação cognitiva) impõe ao plano fenomenal (o relato gravado nas fitas) o estranhamento de um outro. Contudo, o hábito cria a ilusão da identidade. Se gravar fitas em noites de aniversário tornou-se hábito, também transformou-se em ação habitual, paradoxalmente, a epifania vivida por Krapp na meia-idade. Como se lê em The Grove Companion to Samuel Beckett, no verbete sobre esta peça, Krapp e o personagem de That Time exemplificam o fato de que "as grandes decisões e epifanias na vida de alguém, fazem, no final, pouca diferença"227. O tempo passa, e as revelações já não servem mais. O hábito, no entanto, pode transmudar o instante único, numa série de plágios deste instante. Assim, reconhecer na escuridão o elemento a ser abraçado (para a realização de seu opus magnum), estar coerente com esta revelação a longo prazo, por toda a vida, é trair a singularidade mesma da revelação. A dificuldade da harmonização entre epifania e temporalidade está posta pelo próprio léxico empregado por Krapp - 'visão', 'fogo' e 'luz', palavras que qualificam a revelação - para anunciar a 'escuridão' a ser buscada doravante. Os termos antitéticos apontam menos para a sua complementaridade, do que para a dificuldade desta. Krapp velho manifesta-se no palco como a realização pela metade do programa de seu antecessor: vínculos humanos desfeitos, mas obra literária insignificante. $\mathrm{Na}$ escuridão que o circunda, a morte parece

\footnotetext{
${ }^{227}$ Gontarski, S.E. e Ackerley, C.J.; The Grove Companion To Samuel Beckett - A reader's guide to his works, life, and thought, New York: Grove, 2004, p.304.
} 
ameaçá-lo228, contudo é a dúvida que o paralisa. "Talvez meus melhores anos tenham passado, diz Krapp na fita. Quando havia chance de felicidade. Mas eu não os queria de volta. Não com este fogo agora em mim. Não, eu não os queria de volta". Sozinho e obscuro, frustrada a aspiração da magna obra, Krapp velho termina a peça contrapondo-se amargamente a seu outro-eu. Com o olhar fixo no vazio, que sugere a perplexidade de uma clarividência, Krapp parece questionar todo esforço empreendido na direção da escuridão.

Perplexidade se afina com inconcludência, figura que comparece também a esta obra. Krapp não padece da súbita certeza de ter um dia tomado uma decisão equivocada, mas da dúvida em relação a esta decisão. A dúvida paralisa, não conclui. Beckett disse certa vez que Krapp falharia tomasse a decisão que tomasse, e até imaginava uma peça com a situação reversa, em que Krapp não teria dito adeus ao amor, em que a senhora Krapp estaria em cena, mas "seu fracasso, e sua solidão seriam exatamente os mesmos" ${ }^{\text {"229 }}$. ato de cada escolha se acompanha da aniquilação imediata de todas as outras possibilidades abandonadas. Estas serão a sombra dos instantes vindouros no caminho escolhido. Às vezes algo as ilumina: a dúvida, por exemplo. Assim, Krapp velho, rompe com a cadeia do hábito, interrompendo bruscamente a gravação de aniversário, retomando a fita anterior, justamente no ponto em que disse 'adeus ao amor', em que trocou a possibilidade do amor pela possibilidade da obra. Se se trata da última fita que Krapp gravará, se a cadeia

\footnotetext{
228 "Uma outra importante mudança feita por Beckett pela primeira vez na produção do Schiller [Theater] foi associar indiretamente a escuridão, que circunda 'a zona de luz' de Krapp, com a morte". (Knowlson, James; opus cit., p.xvi)

${ }^{229}$ Lawley, Paul; "Stages of Identity: from Krapp's last tape to Play" in Pilling, John (editor); opus cit., p.93.
} 
habitual foi rompida pela dúvida definitivamente, isso não se pode afirmar, afinal o mecanismo habitual é auto-regenerativo. Em Proust, Beckett relembra a angústia do pequeno Marcel no quarto do Grande Hotel em Balbec-Plage, afastado de tudo o que conhecia. Aí, sozinho, sente-se ameaçado pelo ambiente novo, e sofre, pois ainda não se habituou à mudança, e deseja morrer. Seu sofrimento, contudo, cede a "um terror maior, quando ele pensa que à dor da separação sucederá a indiferença, que a privação deixará de ser uma privação quando a alquimia do Hábito tiver transformado o indivíduo capaz de sofrimento em um estranho para quem os motivos daquele sofrimento serão não mais que uma história sem importância..."230. O hábito pode se reorganizar. Apesar do quadro de devastação com que A Última Fita de Krapp se encerra, o final permanece inconcludente. $\mathrm{O}$ fantasma de um recomeço assombra 0 destino derruído do personagem.

Até aqui foram arroladas as figuras analisadas nas peças anteriores: confinamento (ao hábito, aos vícios); circularidade (enquanto repetição e girar em falso); paradoxo (gerado pela impossibilidade de conciliar os planos temporais); e inconcludência. Há, no entanto, uma outra figura que orquestra todo o texto, submetendo as demais a seu controle, e que se pode chamar de 'intermitência'. Em a Última Fita de Krapp a intermitência vem associada ao mecanismo ocular. Como Beckett comentou ao ator Rick Cluchey, "o olho é o

\footnotetext{
${ }^{230}$ Beckett, Samuel; opus cit., p.25.
} 
orgão da interrupação entre luz e escuridão"231 , e Krapp, pode-se acrescentar, é o grande interruptor.

A associação entre olho e interrupção é ilustrada pelos olhos das figuras femininas das quais Krapp se separou:

- Aos vinte e nove anos, Krapp viveu com Bianca, que possuía olhos 'incomparáveis'.

- Aos trinta e nove, Krapp é rejeitado pela enfermeira morena vestida de branco, que tinha olhos feito 'crisólitos'.

- Na mesma época, diz adeus ao amor, num gesto paradoxal em que olhos, acolhimento e separação se misturam: é somente depois de declarar a descrença na relação amorosa, que pode ter com sua companheira um momento de comunhão, explicitado pelo modo como ela acolhe Krapp em seu olhar. "Eu disse novamente - relembra Krapp que achava sem esperança [nossa relação] e que era inútil continuar e ela concordou, sem abrir os olhos. (Pausa) Eu pedi a ela que me olhasse e depois de alguns momentos - (pausa) - depois de alguns momentos ela os abriu, mas os olhos eram como frestas, por conta da claridade. Debrucei-me sobre ela para deixá-los na sombra e eles se abriram. (...) Deixaram-me entrar".

${ }^{231}$ Lawley, Paul; opus cit, p 92. O claro-escuro com que Beckett pontua a peça é analisado amplamente na seguinte obra de James Knowlson: Knowson, James; Lightness and Darkness in the Theatre of Samuel Beckett, London: Turret Books, 1972. 
- Ainda nesta época, Krapp sentado num banco perto do açude, viu o estore $^{232}$ (blind) ser baixado na janela de sua mãe, anunciando sua morte. Olho, 'eye' em inglês, remete foneticamente a ' $l$ ', eu.

Cada par de olhos relembrados por Krapp 'gravaram' uma vez sua imagem e consignaram-Ihe uma identidade. A máxima berkleyliana, 'ser é ser percebido', ressoa nestes olhos que se abriram para ele, mas que também se fecharam, não permitindo assim a manutenção de uma unidade subjetiva.

Submetido à lógica ocelar, Krapp é interruptor - e, pode-se dizer também, separador e ordenador - em outras esferas além daquela dos vínculos humanos:

- No plano escatológico, atua como um 'tipo anal-compulsivo,233, impedindo a dejeção (sua constipação, agravada pela ingestão de bananas, é aludida várias vezes: "impossível evacuação", "the sour cud and the iron stool').

- Empenha-se em regrar sua queda por bananas e pelo álcool, trancando aquelas em gavetas, e limitando aquele a intervalos de tempo marcados no relógio.

- Impede suas memórias de escoarem para o ralo do esquecimento, represando-as, retendo-as nas fitas.

\footnotetext{
${ }^{232}$ Cortina que se enrola ou desenrola presa a uma haste.
}

${ }^{233}$ Cf. Morrison, Kristin; opus cit., p.55. 
- Para isso, separa, antes, em foro íntimo, 'o joio do trigo', ou seja, os fatos memoráveis dos banais.

- Durante a audição das fitas, edita seus relatos parando, avançando e retrocendo, manipulando os registros, descontinuando-os.

Como uma resposta a Proust, A Última Fita de Krapp contraria o papel salvífico da memória involuntária, mas também o papel previsível da memória voluntária. A intermitência frustra a pretensa monotonia do hábito. $\mathrm{O}$ hábito será - tomando por base a experiência de Krapp - um conector ineficiente entre seus muitos 'eus'. As memórias de Krapp, consignadas às fitas, deveriam contentar-Ihe, assim como aquelas supracitadas 'memórias no varal', ao qual se recorre, segundo Beckett, para suprir a "necessidade de reminiscência". Mas o hábito krappiano não cria compromisso firme entre seus 'eus' e 'os desejos de seus eus'. Em A Última Fita de Krapp nota-se, pelo contrário, a total supremacia do tempo sobre o processo habitual. O hábito torna-se aqui não mais do que um impulso, e fadado ao insucesso. O impulso de recordar, o desejo de reviver um fato passado - aparentemente mais forte no velho Krapp, que procura reencenar passagens da infância - é portador de frustação, pelo descompasso entre o sujeito (presente) e o impossível resgate temporal, e é a angústia desta impossibilidade que leva Krapp a romper com a rotina.

Se Esperando Godot e Fim de Partida detinham-se na dialética entre sujeito e objeto, em A Última Fita de Krapp o acento é mais psicológico ${ }^{234}$.

${ }^{234}$ Com diz Rolf Breuer: "o que Descartes e Berkeley são para a relação sujeito-objeto em Beckett, é Marcel Proust para sua psicologia do Eu". (Breuer, Rolf; Samuel Beckett - Eine Einführung, München: Wilhelm Fink, 2005, p.116) 
Talvez, por isso, diferentemente das outras duas peças, nas quais há a quebra da quarta parede ${ }^{235}$, aqui não se detecta este procedimento, e a abordagem ilusionista é mais marcante. Mas não se engane em lê-la apenas pelo viés psicológico. Ao final da peça, Krapp, com o olhar perplexo, deixa a fita já terminada girar em falso no magnetofone $e^{236}$. O aparelho configura uma série de substituições, ele é a moça, seu amor, a quem disse adeus ${ }^{237}$; as bobinas, que giram, substituem os olhos das mulheres relembradas (olhos que the consignaram um dia uma identidade); estas boninas-olhos (eyes) substituem os 'eus' (I) de Krapp ${ }^{238}$. As fitas, o envelope, suportes de suas memórias, jogados no chão, resumem a vida derrocada que é, ao fim e ao cabo, sua magna obra. Ao interromper, ao modo dos olhos, a luz com a escuridão, Krapp cai na armadilha infernal e acaba por 'perder sua alma': esta fica aprisionada na máquina. O quadro final epitoma, mais do que um estado psíquico, um estágio

${ }^{235}$ Por exemplo:

\begin{abstract}
"Clov: ...(Desce, pega a luneta, examina-a, dirige-se para a platéia) Vejo... uma multidão... delireando de alegria...”. (FP, p.76)

"Vladimir: ... (Olha Estragon) Também para mim alguém está olhando, também sobre mim alguém estará dizendo: Ele está dormindo, ele não sabe de nada, deixe-o dormir." (EG, fr, p. 178)
\end{abstract}

236 Para Paul Lawley, o final da peça opera uma reviravolta, em que Krapp, a princípio exercendo sua autoridade sobre o magnetofone, acaba, ao final, subjugado por ela. (Lawley, P.; opus cit., p.102)

237 Idéia que é acentuada nas rubricas revisadas por Beckett na montagem do Schiller Theater, em que o autor prescreve quadro que sugere um abraço amoroso em torno do magnetofone: "nos próximos instantes, cabeça gradualmente desce para repousar finalmente na mesa. Mão direita tocando a base do gravador, mão esquerda do botão liga para o desliga, enquanto a cabeça desce". (Knowlson, J., opus cit., p.8)

238 "O brilho inanimado do aparelho finalmente substituiu tanto os 'olhos' [eyes] do amor como o 'eu' [I] da identidade, deixando Krapp, como Beckett escreveu na sua edição Faber, 'terrivelmente quieto'”. (Idem, ibidem, p.65) 
avançado da modernidade. Esvaziada a dimensão subjetiva em prol de uma tentativa de controle desta mesma dimensão, o sujeito moderno iguala-se às máquinas que cria. Aqui, nestes segundos silenciosos, enquanto a luz decresce, platéia e palco se confundem ${ }^{239}$ na penumbra, contemplados por estes 'olhos-bobinas', que são mantidos sob o foco de luz.

\footnotetext{
${ }^{239}$ Novamente, como nas outras peças analisadas, Beckett inclui a platéia na situação exposta. O que pode ser corroborado também pela lembrança da rubrica inicial de A Última Fita de Krapp 'um fim de noite no futuro'. Este futuro - aparentemente estabelecido para localizar verossimilmente o magnetofone recém-inventado na época da encenação - pode ser compreendido de um outro modo. Se a peça se passa no futuro, o passado ouvido na fita - em que tem vez um personagem orgulhoso, arrogante, auto-confiante - corresponde ao presente da audiência. Assim entendido, o futuro presentificado de Krapp observa com ironia a gente bem acomodada e até segura aposta ao palco, cujo futuro está ali anunciado.
} 


\section{Dias Felizes \\ ৯ Dissimulação əo}

"How little subject matter counts...! Subject matter is immaterial!"

Edward Weston 
A centralidade frontal de Winnie, sua indubitável pertença ao palco - que literalmente a engole - exacerba imageticamente a figura do confinamento. Ela está prisioneira do palco e inelutavelmente à mercê da demanda teatral. Ao som da campainha, abre os olhos e começa o 'seu dia'240. A campainha - que no teatro alerta atores e público para o início do espetáculo -, ao ser assimilada à cena, expõe a bizarria deste dia que não é dia, mas, sim, uma eternidade hiperiluminada. A pertença da campainha à situação ficcional sugere também o artificioso de outros elementos nomeados. A 'luz ofuscante' prescrita pela rubrica -, também nomeada por Winnie como 'fornalha de luz infernal' ou 'sol infernal' ou ainda 'santa luz'241 - que devassa a paisagem desertificada -, seria nada mais do que os refletores ligados em alta potência. Mas nem a iluminação nem o confinamento, que obrigam a personagem à máxima exposição, garantem sua inteligibilidade.

É impossível não estranhar este quadro: uma senhora de classe média, enterrada até a cintura no meio do deserto, matraqueia e remexe a bolsa, com a naturalidade de quem procura um batom para passar antes de sair. Beckett interpõe, no entanto, entre Winnie e a platéia, um casal. Este, ao mesmo tempo que espelha a inquietação da audiência - compondo um teatro dentro do

\footnotetext{
${ }^{240}$ Sempre que Winnie se refere a dia ou noite, ou à passagem do tempo, ou à morte, ela exclama o bordão "ah, o velho estilo". Como lembrando de um tempo, que já não é o seu, em que houvera dias e noites e o tempo passava e as coisas finavam.

${ }^{241}$ As citações de Dias Felizes são traduzidas por mim, com apoio da edição alemã trilingüe (Samuel, Beckett; Glückliche Tage, Happy Days, Oh les beaux jour, Berlin: Suhrkamp, 2001) e das traduções, não publicadas, de Fábio de Souza Andrade e Rubens Rusche.
} 
teatro $^{242}$ - proteje a personagem de seu olhar direto (e a platéia de ser descoberta). O casal Cooker ou Shower ${ }^{243}$ - Winnie não lembra ao certo o nome - irrompe em sua memória justamente no momento em que se sente observada $^{244}$. Trata-se do último par de humanos que passou por aquelas paragens, conta Winnie, e que, intrigado com o quadro a sua frente - o qual inclui o passivo marido -, interrompe a caminhada cheio de espanto: 'O que ela está fazendo? O que significa isso? Por que ele [o marido] não a desenterra? De que ela the serve assim? Ela veste alguma coisa por baixo? etc'. Espelhando as dúvidas da platéia, o par, no entanto, parte sem respostas. Se o tableau perturbou-o, a contradição entre o gestual cotidiano da personagem e sua situação, entre seu discurso banal e sua situação, continua a intrigar o público. Que Beckett trabalhe no campo da ironia, não há dúvida. O título, Dias Felizes, e os nomes dos personagens, Winnie e Willie, são prova disso. Pois o que se testemunha é, em verdade, uma eternidade torturante, para a qual a nada vitoriosa Winnie e o impotente Willie ${ }^{245}$ ansiariam um fim:

\footnotetext{
${ }^{242}$ Note-se, portanto, o efeito-matrioshka em nova aparição.

${ }^{243}$ Como explica Paul Lawley, Shower e Cooker são palavras de procedência germânica: schauen (olhar) e gucken (olhar, espreitar). Lawley lembra, inclusive, que Zuschauer significa, em alemão, o espectador de teatro. O espelhamento destes personagens com a platéia é, portanto, evidente. (Lawley, Paul; "From Krapp's Last Tape to Play" in The Cambridge Companion to Beckett, Cambridge: Cambridge University Press, 1996, p.97) Deve-se lembrar também que em francês o casal é nomeado como Piper, que remete ao verbo inglês peep (espreitar). Também não se pode esquecer que show, em inglês, é mostrar, apresentar.

244 "Estranha sensação - diz Winnie - de que alguém está me olhando. Estou vívida, depois esmaecida, vívida de novo, depois esmaecida e assim por diante, indo e vindo, passando e repassando no olho de alguém".

${ }^{245}$ A impotência de Willie, dentro do contexto da esterilidade geral, é analisada mais adiante.
} 
- Winnie declara ter como consolo para a sua situação o 'dia feliz' em que sua 'carne derreterá'.

- Chama de 'consolos' também aos seus pertences - que a ajudam passar 'o dia' -, dentre os quais se destaca um revólver.

- Constatando a aridez a sua volta, dá graças que nada germine, temerosa da ressurreição de 'toda esta porcaria'.

- No segundo ato, enterrada até o pescoço, alerta o abscôndito Willie da presença do revólver, como que a transferir para ele o encargo possível do fim.

Mas o fim não virá. A condição teatral é de repetição, recomeço, circularidade, e a personagem parece entender isso, ainda que anseie finar. Quando seu pára-sol entra em combustão, tem a sensação de déjà-vu. Confiante neste pressentimento, quebra também um espelhinho, profetizando ${ }^{246}$ a pronta restauração destes objetos. E não é o que ocorrerá quando a peça for reencenada? E não é o que ocorre no segundo ato? Winnie compreende inclusive o tipo de eternidade a que o personagem teatral é confiado: o presente do personagem é sua eternidade. Por isso diz: "se a terra um dia devesse cobrir os meus seios, então eu jamais teria visto os meus seios, ninguém jamais teria visto os meus seios". Ao início do segundo ato, com os seios de fato encobertos, filosofa novamente sobre o paradoxo desta

\footnotetext{
${ }^{246}$ Winnie também antecipa o seu estado futuro (o modo como aparecerá enterrada até o pescoço no segundo ato) quando diz: "Estou com - leva as mãos ao chapéu - isso, estou com meu chapéu - abaixa as mãos - não posso tirá-lo agora. Pausa. E pensar que há momentos em que não se pode tirar o chapéu, nem para salvar a própria vida". Ao aludir a sua próxima etapa (estar enterrada até o pescoço no segundo ato) como algo passado, Winnie deixa claro o movimento circular a que está submissa.
} 
condição: "Antes... agora... como é difícil para o espírito. (Pausa) Ter sido sempre aquela que eu sou - e ser tão diferente daquela que eu era". 0 passado, ao qual pode aludir, não a determina. Pois entre passado e presente há o 'intervalo'247 intransponível. Winnie será eternamente aquela que o palco, no presente, revela. Mas enquanto no inferno de Dante os pecadores encenam eternamente os mesmos horrores, Winnie tem a desvantagem de estar obrigada na rota, não de um círculo, mas de uma espiral, e pior, uma espiral degenerativa. "Eu costumava dizer [...] - confessa Winnie -, você é imutável, nunca haverá diferença entre uma fração de segundo e a seguinte". A diferença, contudo, existe e se manifesta premendo seu pescoço. A terra, de grão em grão, ou de fração de segundo em fração de segundo, avança. Não obstante, como já foi comentado sobre Fim de Partida, o monte não se completará, pois em Dias Felizes também não se conciliam os planos dramático (o encaminhamento para um fim) e teatral (repetição virtualmente sem-fim do espetáculo). "Por quê [então] dizer tudo isso de novo?", se pergunta Winnie, já sem movimentos e com poucos recursos verbais. Por quê? Por obrigação: "Eu preciso dizer mais".

A infernal condição de Winnie, que impele sua fala, depende, no entanto, da presença de um outro que a perceba. Ainda que a campainha a alerte de que deve se expor, são Willie, o casal Shower (ou Cooker) e os espectadores

\footnotetext{
${ }^{247} \mathrm{O}$ intervalo entre um ato e outro figura em termos dramatúrgicos o que se nomeou aqui de intermitência. Mesmo o coma a que é relegado o personagem entre uma apresentação e outra pode ser compreendido como decorrência da intermitência (que intervala o ciclo das apresentações).
} 
da peça que a coagem ${ }^{248}$. Por isso, às vezes, e veladamente, às vezes Winnie externa seu desejo de que Willie morra. Logo ao começo da peça, abre um tubo de pasta de dentes ao mesmo tempo em que busca 'acordar' o campanheiro. 'Coitado do Willie', comenta, 'não dura muito'. Apesar de 'não dura muito' referir-se ao tubo de pasta, o qüiproquó denuncia já seu anseio de libertação, que também comparece na sugestiva canção 'I love you so', tocada na caixinha de música e mais tarde cantarolada por ela, canção extraída da opereta A viúva alegre. Quanto aos indiscretos senhor e senhora Shower (ou Cooker), Winnie é bem explícita: "Deixem-me, em nome de Deus, e caiam fora. Caiam mortos!". Ainda que não tenha externado sua raiva ao casal no momento em que a importunavam, externaliza-a quando rememora a história deles, sob o testemunho de Willie e da audiência. Esta última, inclusive, sintase igualmente amaldiçoada, e não se engane quando, no início do segundo ato, a personagem, recém-despertada, Ihe parece agradecida: "Salve, santa luz. [...] Alguém está olhando para mim ainda. Se preocupando comigo ainda. É isso que considero tão maravilhoso. Olhos nos meus olhos". Como já foi dito, Beckett trabalha na esfera da ironia. Nem a luz é santa ${ }^{249}$, nem são

\footnotetext{
${ }^{248}$ O que se chama de coatividade é justamente a coação imposta aos personagens - que faz parte de sua condição de personagem -, de expor-se para uma audiência. Se em Dias Felizes a coatividade já se manifesta, é em Comédia, porém, que aparece explicitamente, notadamente na relação dos personagens com o refletor, como se verá mais adiante.

${ }^{249}$ Como explica Kristin Morrison, "Salve, santa luz" faz referência ao Paraíso Perdido de Milton (3:1), que também é lembrado na seguinte passagem: "Oh, fugazes alegrias [...] oh, alguma coisa, duráveis desgraças" (10:741-2). "Aqui - diz Morrison - toda a economia divina e a plenitude da criação, o grande pecado de Adão e Eva e feliz erro, a perda cósmica e ganho ficam em contraste irônico com a nulidade de Winnie". (Morrison, Kristin; Canters and
} Chronicles - The Use of Narrative in the Plays of Samuel Beckett and Harold Pinter; Chicago, Londres: The University of Chicago Pres, 1995, p.44) 
maravilhosos estes olhos escrutinadores que, em voyeurístico silêncio, a obrigam a dizer mais.

A ironia empregada por Beckett em Dias Felizes traduz-se dramaturgicamente como dissimulação. É significativo que este mecanismo apareça no corpo da peça ligado ao modo como os personagens tratam a sexualidade. Há muitos exemplos:

- Estimulada pelos classificados de jornal que Willie lê em voz alta, Winnie rememora - de modo nada lisonjeiro para o consorte - amores antigos. Um tal de Carlinhos Hunter que a botou no colo, um Johnston ou Johnstone que the deu o primeiro beijo na estufa do jardineiro, um certo Browning que gostava de 'ficar por cima'.

- E, no segundo ato, sem poder voltar-se para trás, e incerta da presença de Willie, fica à mercê da audiência, e é compelida por seus voyeurs cuja autoridade parece provir justamente de seu silêncio - a uma história mais constrangedora. Esta história é contada em terceira pessoa. Winnie dissimula ${ }^{250}$ ter sido a vítima do ocorrido, atribuindo a história a uma menina chamada Mildred. Quando Mildred tinha cinco anos, um rato subiu-lhe pelas coxas, e, apesar dos gritos, o socorro da família chegou 'tarde demais'. O que houve, não se sabe; mas toda a descrição preliminar ao fato, que dá conta da menina despindo uma boneca, depois de descer uma escadaria proibida, sugere algum tipo de agressão sexual.

${ }^{250}$ A dissimulação de si mesmo como agente da história narrada, aparece e de modo mais radical, em Eu Não. 
- A cena de uma formiga que passa inopinadamente no deserto carregando ovinhos, arranca risos do casal, ao ser nomeada de 'formicação'.

- A rejeição de Winnie à gravura pornográfica - ofertada por Willie - é atenuada pela demora com que ela a investiga, ajudada por uma lupa.

A sexualidade, contudo, neste par, que demonstra tanto interesse pelo tema, é inoperante. Haja vista o soterramento impeditivo a que a personagem está submetida. Além disso, levando-se em conta o modo reiterado com que Winnie pretere Willie em suas memórias, a favor de qualquer outro homem, Willie parece também sexualmente falto. E é ele mesmo quem define seu estado sexual ao explicar para Winnie o significado da palavra 'cevado'. "O que é mesmo um cevado?", pegunta-se a personagem, que encontra as seguintes palavras escrita em miniletras na frase gravada sobre a escova de dentes: 'cerdas de cevado'. A resposta de Willie tarda, mas é precisa: "Suíno macho castrado. [...] Criado para o abate".

Com exceção da formiga, que atravessa a cena carregando seus ovos, tudo é estéril em Dias Felizes. O gramado calcinado, a paisagem desértica, compõem com os personagens. Ele, a preencher as horas entre a leitura de classificados de jornal (notícias ultrapassadas há muito tempo) e o sono. Ela, no apego a seus objetos cotidianos e resquícios culturais (pedaços de poemas, trecho de canção ${ }^{251}$ ), últimos dejetos do mundo. A esterilidade aqui vige principalmente como inocuidade do discurso ou da palavra. O que se mobiliza

${ }^{251}$ Como diz: "Resta parte de nossos clássicos para passar o dia". 
em termos de discurso serve para distrair da morosidade decadente de um dia sem fim. Repete-se o já dito - a infrutuosa leitura do jornal antigo, as incompletas citações dos clássicos -, e o que se narra é instrumento para dissimulação. Trata-se de uma palavra (ou discurso) habituada, cuja característica fundamental, Winnie percebe ao declarar: "Há tão pouco a dizer. Pausa. E se diz tudo. Pausa. Tudo o que podemos. Pausa. E nem uma palavra de verdade, em parte alguma". Talvez seja por isso que neste universo - em que a palavra desponta como algo refratário à verdade - o olhar ganhe tanto peso cênico. Se as palavras são o véu para a dissimulação, o olhar que se sobrepõem ao ouvido, tem acesso à 'verdade'. Sem nenhum sentido metafísico, esta tem caráter quase fenomenológico: seria simplesmente um assentir ao que aparece. Pois ainda que Winnie estranhe o lugar em que está, não quer se estranhar aí, pois mantém sua rotina. Se o olhar, dos Shower e da platéia, ameaça ${ }^{252}$, mais contundente é o olhar trocado entre a personagem e Willie, gesto que encerra a peça.

Willie, durante todo o tempo escondido por um aclive que aparentemente não consegue transpor, desponta, ao final da peça, no campo de visão de Winnie (e da platéia), vestido de gala e movido por anseio ignorado. Se vem para ganhar um beijo ou pegar a arma; se vem para matar-se ou matar; se é um golpe de misericódia que pretende desferir; se quer, simplesmente, partir; não se sabe. O final é inconcludente, mas o olhar demorado trocado entre ambos, sugere a duplicação de um espelhamento no qual a platéia já se soube incluída: "Alguém está olhando para mim ainda. [...] Olhos nos meus olhos". Se

\footnotetext{
252 Uma atmosfera mais ameaçadora é sugerida no segundo ato, quando Winnie declara estar ouvindo gritos.
} 
for assim, entenda-se o além-palco também como um deserto assombrado por flatus vocis. 


\section{Peça \\ a Coatividade \&}

"Senhor, o que eu experimento, o que eu sinto, não posso e não quero dizer! [...] Creia, senhor, acredite que sou uma personagem não 'realizada' dramaticamente, e que estou mal, muitíssimo mal, na companhia deles! Deixem-me quieto!'

Luigi Pirandello, Seis Personagens à Procura de um Autor 
Vêem-se três urnas sobre o palco, encimadas por três cabeças, das quais não se identifica a idade. A impressão é que cabeças e urnas estão em simbiose há muito tempo. O confinamento radical dos personagens - duas mulheres e um homem - singulariza a cabeça como matéria dramática, mais especificamente suas falas. O confinamento facilita, ainda, o trabalho da exploração destes seres, realizado por um refletor. Localizado na ribalta, o refletor atua como um inquisidor, que retira a alocução de seus réus à medida que os ilumina. $O$ confinamento às urnas radicaliza e expõe também a própria condição do personagem dramático: encerrado num certo espaço e num certo tempo. Ainda que reportem seu passado, fazem-no na emergência de uma eterna atualidade. Por isso 'H' (o homem) confessa: “... não apenas tudo acabado, mas tudo como se... nunca houvesse acontecido"253. Para o personagem dramático o passado é aquilo que parece nunca 'ter acontecido', pois enquanto personagem encontra-se confinado ao presente da atuação. ' $H$ ', mais explicitamente do que Vladimir ou Clov ou Winnie, sabe-se partícipe de uma peça teatral: "Agora eu sei - diz - aquilo tudo foi apenas... uma peça. E isso tudo? [...] Quando é que isso tudo não terá sido... apenas uma peça?". 'Aquilo tudo' remete à primeira parte do texto, em que é relatada a experiência de um triângulo amoroso. 'Isso tudo' remete ao segundo momento do texto, em que os personagens tomam consciência da coação exercida pelo refletor. 'Isso tudo' e 'aquilo tudo', ao ser qualificado de peça - ou play, em inglês, e

${ }^{253}$ A tradução é minha, baseada nas versões francesa e inglesa (Beckett, Samuel; The Complete Dramatic Works, London: Farber and Farber, 1990. Beckett, Samuel; Comédie et actes divers, Paris: Minuit, 1990). Tive também acesso à tradução de Rubens Rusche usada em sua montagem de 1986. 
comèdie, em francês -, faz situar a experiência das cabeças falantes em um corpus scenicus inultrapassável.

A intermitência, em Peça, assim como em A Última Fita de Krapp, tem no mecanismo ocelar o seu parâmetro. Como diz 'H' para o refletor: "E agora que você é... apenas um olho. Nada mais do que um olhar. Sobre o meu rosto. Em eclipses. [...] Apenas um olho, sem mente. Abrindo e fechando sobre mim. [...] Estou pelo menos... sendo visto?" O refletor, assim como Krapp, é um interruptor (ou editor). Passa rapidamente seu foco de luz de um personagem ao outro, cortando suas falas. Estes enarram quando iluminados e se calam quando no escuro. Cada um ignora a presença do outro, e, curiosamente, mesmo interrompido, prossegue do ponto em que havia parado ${ }^{254}$. Se os personagens revezam suas aparições sob a iluminação constante mas móbil do refletor, este último também vige na intermitência de breves blackouts. Blackouts que dividem a peça em quatro momentos principais ${ }^{255}$ :

1) introdução - brevíssima - na qual as três cabeças iluminadas resumem, falando ao mesmo tempo, o que dirão na segunda parte $(+$ blackout);

2) primeira parte, em que as cabeças, individualmente iluminadas, dão suas versões de um triângulo amoroso (+ blackout);

3) segunda parte, em que buscam entender a coação exercida pelo refletor (+ blackout);

\footnotetext{
${ }^{254} \mathrm{O}$ soluço constante de ' $\mathrm{H}$ ', que pontua suas falas, reproduz em microescala a intermintência provocada pelo refletor.

${ }^{255}$ No entanto, são contados oito blackouts (de cinco segundos cada um) durante a peça.
} 
4) repetição de toda a peça até o cair do pano.

Apesar do cair do pano, fica sugerido que tudo se repetirá ao infinito. Peça revela estrutura circular e, ao mesmo tempo, de intermitência.

Da intermitência deriva-se a figura da inconcludência. Pois com o segundo blackout - entre a primeira e segunda partes -, oblitera-se o nexo que coordenaria a história do triângulo amoroso com a situação de confinamento dos personagens nas urnas. Fica supresso, portanto, pelo breve instante de escuridão, o elo que poderia explicar a passagem da condição pretérita ultramóbil dos personagens - a azáfama do triângulo amoroso - à sua condição presente, estática. Não se sabe como os personagens chegaram a esta condição, nem se indica a possibilidade de um desenlace. Alguns comentadores entenderam este gap como a passagem da vida para a morte. Gonstarski, por exemplo, entende Peça como a encenação da persistência da consciência além-túmulo, ilustrada pelos tormentos post-mortem dos três protagonistas, afligidos por uma 'luz inquisitorial'256. Preservar a lacuna, respeitar a inconcludência, parece, contudo, mais prudente. A incerteza é constitutiva da literatura de Beckett. Se a morte está em cena é mais operativo vinculá-la aos elementos da própria peça, quais sejam, vestígios dramáticoteatrais: um refletor, cabeças-falantes, clichês passionais. Afinal, até em seu título está indicado o escopo desta obra: Peça. A morte parece, assim, referirse mais ao teatro dramático. O tema do triângulo amoroso, por exemplo, é tão banal, que a rubrica pôde prescrever sua elocução em velocidade acelerada.

${ }^{256}$ Cf. Gontarski, S.E.; The Intent of Undoing in Samuel Beckett's Dramatic Texts, Bloomington: Indiana University Press, 1986, p.90. 
As palavras em Peça não são literárias ao modo tradicional, são mais falatório e não portam uma mensagem. São lançadas como resíduo, pasticho, e só alcançam seu status artístico pela completa integração aos aspectos formais da obra. Beckett investiga o teatro dramático a partir de seus elementos irredutíveis: luz e fala. E, ao fazê-lo, evidencia a morte (ou inutilidade) de toda a parafernália que, sempre que é recuperada, dissimula o caráter agônico do drama.

Se Peça se explicita naquilo que é, seus personagens dissimulam. Por mais que o refletor os atormente, os três protagonistas não revelam qual foi o seu destino após a desintegração do triângulo amoroso. Cada um deles qualifica o outro de 'coitado', mas não atribui a si o mesmo quinhão de compassividade, recusando-se a estar no mesmo 'nível' daqueles. Também o refletor, 'olho sem mente', parece dissimular, com seu trabalho frenético, a falta de sentido - ou execução puramente mecânica - de sua tarefa.

Beckett cria uma conexão explícita entre luz teatral e violência. A imagem de rostos agressivamente iluminados, de confissões retiradas à força pela projeção de luz ofuscante, é emblemática de interrogatórios policiais abusivos, e tem inúmeros exemplos que vão da Gestapo ao FBI macarthista ${ }^{257}$. Entender o tipo de violência que uma peça faz transparecer ajuda a definir o que aqui se nomeia coatividade.

${ }^{257}$ Cf. Kenner, Hugh; A Reader's Guide to Samuel Beckett, New York: Syracuse University Press, 1996, p.153. 
A coação do refletor explora os personagens até o limite de sua ficcionalidade. Não tendo como expor-se além do que são, o trabalho incansável do refletor força a circularidade do texto. Os personagens recuam para um recomeço, quando não podem prosseguir. Se almejam a escuridão final, se buscam o repouso e a paz ${ }^{258}$, alcançam, ironicamente, o frenesi e uma treva insuficiente. Nas palavras de M1 (mulher 1), o que obtêm é apenas uma 'penumbra infernal'. Mas a esta violência acresce-se outra e em forma de paradoxo: que as cabeças, devassadas por luz intensa, não sejam vistas. Como disse ' $H$ ': "E agora que você é... apenas um olho. Nada mais do que um olhar. Sobre o meu rosto. Em eclipses. [...] Apenas um olho, sem mente. Abrindo e fechando sobre mim. [...] Estou pelo menos... sendo visto?" O frenesi de iluminação deste 'olho sem mente' não garante a visibilidade de seus réus. Esta violência é sofrida na perplexidade com que 'M1' (mulher 1) comenta: "E que tudo esteja caindo, desde o começo, no vazio. Nada é perguntado. Ninguém me pergunta absolutamente nada". "M2" (mulher 2) é mais enfática: "Você está me escutando? Alguém está me escutando? Tem alguém olhando para mim? Alguém ao menos se preocupa comigo?" Se a condição de personagem é berkleyana, pois ele é quando é percebido, o registro existencial das três cabeças de Peça está ameaçado, se coagidas por uma força irracional. A violência a estes seres manifesta-se ainda pela busca de um sentido para sua situação. Como diz 'M2': "Não há dúvida de que cometo o mesmo erro de quando era o sol que brilhava, procurar sentido onde possivelmente não há nenhum". E 'M1' confessa de modo similar: "Se pelo

\footnotetext{
${ }^{258}$ Como diz H: "Quando isso mudou pela primeira vez, eu louvei a Deus, juro. Eu pensei, Está feito, está dito, agora tudo vai se apagar". E M2 declara: "Afirmar que eu não esteja decepcionada, sim, eu estou. Eu contava com alguma coisa melhor. Mais repousante".
} 
menos pudesse pensar, Não tem nenhum sentido nisto... nenhum. [Mas] Não posso." A cabeça impõe a necessidade de um sentido ${ }^{259}$ e a insistente operação do refletor obriga os personagens a uma interpretação do motivo de sua tortura: 'M1' pede perdão e questiona 'se não está dizendo toda a verdade'; 'H' também se pergunta 'se não estaria escondendo algo'; 'M2' espera que o refletor tenha pena dela e a deixe, uma vez que 'faz o que pode'.

A aflição dos personagens em descobrir o sentido da situação espelha certamente aquela da platéia. Do mesmo modo, o refletor-olho espelha o olhar voraz de uma platéia habituada a obter revelações. A platéia, pela dinâmica especular, está incluída neste jogo de coatividade: sendo ao mesmo tempo torturada (sofre a falta de um sentido) e torturadora ${ }^{260}$ (sua busca por sentido mantém os personagens em atividade). Se há nas peças de Beckett, como notou Luiz Fernando Ramos, "um constante desvendar dos mecanismos dramáticos consagrados[; as] personagens [sendo] reveladas como partes de uma engrenagem e suas ações, se alguma finalidade possuem, [sendo] a de cumprir esse desvendar"261, então, pode-se acrescentar que também a platéia é investigada e revelada como parte de tal mecanismo. Se o refletor é a força que coage os personagens, a força que pressupostamente coage a mecânica

${ }^{259}$ Como comenta M1 (mulher 1), dando conta do trabalho incansável da mente: "Não posso fazer nada... para ninguém... não mais... graças a Deus. Então deve ser algo que eu deva dizer. Como a cabeça funciona ainda!".

${ }^{260}$ Paul Lawley propõe que, do mesmo modo como Winnie em Dias Felizes vincula sentido de espetáculo à violação sexual, as três cabeças de Peça, encenando uma paródia grotesca de peças de amor, reforçam o nexo entre papel da assistência e violação. (Cf. Lawley, Paul; "From Krapp's Last Tape to Play" in The Cambridge Companion to Beckett, Cambridge: Cambridge University Press, 1996)

${ }^{261}$ Ramos, Luiz Fernando; O Parto de Godot: e outras encenações imaginárias: a rubrica como poética da cena, São Paulo: Hucitec/Fapesp, 1999, p.60. 
do refletor é a própria platéia. Se assim for, a violência que o teatro de Beckett denuncia é aquela imposta pelo hábito. Investigando a platéia no limite de sua função, Beckett questiona este postar-se em silêncio, este camuflar-se no escuro, esta contemplação cega ao mal-estar daqueles seres híbridos (fictícios, mas ao mesmo tempo de carne e osso) que pressentem a irracionalidade do próprio destino, mas ignoram seu nome: o hábito dramático, a irracionalidade dissimulada de seus receptores. A função da platéia no teatro de Beckett é questionada por um inusitado Verfremdungseffekt - que vai além daquele proposto pelo teatro épico. Beckett faz estranharem-se estes 'olhos sem mente', que por força do hábito, não vêem além das expectativas dramáticas, revelando-se nada mais do que consumidores insaciáveis de confissões. 


\section{Epílogo: Inferno}

"Por que tanto teu olhar em nós se espelha?"

Dante Alighieri, Inferno

Carla Locatelli, em seu livro Unwording the World: Samuel Beckett's Prose Works After the Nobel Prize, propõe uma divisão tripartite para a obra de Beckett $^{262}$. A primeira fase traria a marca da paródia. Em intercâmbio com outras obras, e para contradizê-las, este período, assumindo a tradição literária, seus cânones e estruturas básicas, transgrediria, contudo, no registro da fábula. More Pricks than Kicks e Murphy são exemplos desta fase, e, se parodiam a Divina Comédia ou o Bildungsroman, não subvertem, porém, o modo no qual a história pode ser contada. A noção de gênero que neste momento é preservada será, no entanto, posta em xeque na fase posterior, que Locatelli nomeia 'metanarrativa'. Aqui Beckett procede a uma corrosão interna dos gêneros. Molloy, por exemplo, pode ser entendido como um romance que visa acabar com o gênero romance. Ainda é possível neste momento encontrar uma "clara resolução do sentido, o qual implica [contudo] uma negação ou contradição da verdade de um texto (não-cômico) recebido"263. As obras desta segunda fase de Beckett, como diz Locatelli, "não precisam pressupor o mundo. Elas simplesmente pressupõem uma ontologia lingüística que será

262 Locatelli, Carla; Unwording the world: Samuel Beckett's Prose Works after the Nobel Prize, Philadelphia: University of Pennsylvania Press, 1990, pp.80-111.

${ }^{263}$ Idem, ibidem, p.83. 
posta sob constante escrutínio e desafio"264. A terceira fase, finalmente, seria de ordem discursiva e bastante complexa. Aqui a obra apresentaria uma suspensão auto-reflexiva do sentido, um discurso movediço, que enfrentaria literariamente o seguinte dilema: "o papel da linguagem não pode ser tematizado se se esquecer que é a linguagem que permite esta tematização"265. Worstward Ho e Mal visto Mal dito são exemplos deste momento.

Propondo-se mapear em três períodos as estratégias cômicas da narrativa beckettiana, a divisão proposta por Locatelli admite, no entanto, outros desígnios. Assim, é possível acomodar as cinco peças aqui analisadas à segunda fase sugerida da obra, acrescentando, porém, à sua qualidade metanarrativa ${ }^{266}$, a qualidade metadramática. Como foi demonstrado nas análises pregressas, constata-se um empenho de Beckett em denunciar os elementos intrateatrais dos textos. Se o tempo e o espaço são investigados em Esperando Godot como marco zero de qualquer pensamento sobre o teatro aparecendo duplicados nas figuras de circularidade e confinamento -, em Fim de Partida, A Última Fita de Krapp, Dias Felizes e Peça são evidenciados outros elementos do arcabouço dramático. Deste modo, o progresso dramático é questionado em Fim de Partida, e em Dias Felizes e Peça a relação entre luz e exposição do personagem está posta em relevo. De modo sutil, A Última Fita de Krapp, por sua vez, joga com as unidades de tempo e lugar,

\footnotetext{
264 Idem, ibidem, p.95.

265 Idem, ibidem, p.100.

${ }^{266}$ Pois também a narração é investigada na obra teatral, mas em segundo grau.
} 
desestabilizando-as, pois alcança concentrar três épocas diferentes no presente cênico.

Se em cada texto realça-se o papel de uma ou duas figuras (ou procedimentos formais), todas as figuras, no entanto, percorrem os cinco textos (em maior ou menor grau). Batizando-as de 'figuras infernais' faz-se jus a Beckett, quem, pela voz de seus personagens, outorga ao palco, à luz, ao drama, à platéia, tal atributo. A Divina Comédia de Dante, visitada e revisitada por Beckett ${ }^{267}$ ao longo de sua vida, marca a primeira fase de sua obra com referências ao Purgatório ${ }^{268}$; o ambiente infernal, contudo, que está espelhado principalmente em seu teatro, encontra correspondência na segunda e até terceira fases de sua obra. No ensaio "Dead heads: damnation-narration in the 'dramaticules'”, Keir Elam inventariou a presença do Inferno nos textos teatrais $\operatorname{curtos}^{269}$. Vai e vem, Eu Não, Aquela Vez e Improviso de Ohio são estudadas em sua correspondência com o Inferno dantesco. A boca em Eu Não, por exemplo, anel ou círculo solto no espaço, remeteria aos círculos do inferno, mas também ao personagem Bocca, traidor florentino, que aparece no

${ }^{267}$ Como lembra James Knowlson: “...o amor por Dante foi mantido por Beckett até o final de sua vida e influenciou profundamente sua escrita em diferentes momentos de sua carreira". (Knowlson, James; Damned to Fame, Edinburgh, Bloomsbury, 1997, p.52-3.

268 O livro Beckett's Dantes de Daniela Caselli investiga abrangentemente a pregnância de Dante em Beckett, principalmente no que tange ao Purgatório. (Caselli, Daniela; Beckett's Dantes: Intertextuality in the Fiction and Criticism, Manchester/New York: Machester University Press, 2005.) Um artigo que merece ser lembrado é "Beckett, Dante, and the Metaphorical Representation of Intangible Reality" de Rubin Rabinovitz. (Rabinovitz, Rubin; "Beckett, Dante, and the Metaphorical Representation of Intangible Reality" in Alan W. Friedman, Charles Rossman, Dina Sherzer (editors); Beckett Translation/Translating Beckett, University Park: Pennsylvania State University Press, 1987, pp.57-63.) ${ }^{269}$ Pode-se datar o surgimento dos dramaticules a partir de 1965, com a composição de Vai e Vem. 
canto XXXII, imobilizado e mutilado. Características como mutilação, escuridão, repetição, evasão, circularidade, são estudadas abrangentemente por Elam em visada iconográfica e semiológica. Sendo a visada desta tese dramatológica, o ensaio de Elam contribui, no entanto, como estímulo, para que, a partir da constatação da pregnância do Inferno de Dante na obra de Beckett, possa se pensar um inferno exclusivamente beckettiano, que se vale daquele outro para objetivos próprios, ou mesmo que sobrepuja aquele com a criação de uma nova categoria infernal.

Diferentemente de Elam, o que se identificou neste estudo é o fato de já nas primeiras peças teatrais de Beckett notar-se a utilização de recursos formais com traços 'infernais'. Existe certamente uma correspondência destes mecanismos com aqueles desenhados pelo poeta florentino. Os pecadores do Inferno estão sujeitos ao confinamento, à circularidade (que inclui repetição), à coatividade assim como os personagens do inferno teatral de Beckett. Contudo, se aqueles conhecem as razões de sua pena, e cumprem-na inequivocamente, estes padecem de incertezas e incongruências, obrigados à cadência de uma função dramática declinante. Paradoxo, inconcludência, intermitência e dissimulação dão conta desta espécie de inadequação das funções dramáticas.

O interesse da detecção das 'figuras infernais' extrapola, porém, o âmbito de cada peça analisada e pode erigir-se em instrumental crítico para a compreensão do teatro subsecutivo de Beckett, bem como de outros gêneros explorados pelo autor. $\mathrm{O}$ estudo dos dramaticules à luz destas figuras revela 
como estes se estruturam sobre aquelas. Em Eu Não, por exemplo, inventariase todas as chamadas figuras infernais:

- a repetição da narrativa (ou circularidade), haja vista a última palavra do texto, 'recomeçar';

- o confinamento ao palco (revelado pelo raio de luz - refletor - e um bulício sofrido pela personagem (a platéia);

- a dissimulação, estampada no próprio título (Eu Não), que irmana a personagem de outros dissimuladores como Winnie, M1, M2, $\mathrm{H} \mathrm{e}$ Hamm;

- a intermitência exacerbada de um discurso truncado e fragmentário;

- a coatividade, a que a condição de personagem obriga;

- a inconcludência do plano fabular, sendo relatada uma história que não se explicita, deixando em aberto para o público as possibilidades de preencher as lacunas do enredo;

- o paradoxo, que em Fim de Partida se explicita como impossível conciliação entre as lógicas teatral e aquela do (des)drama beckettiano.

Nos outros gêneros trabalhados por Beckett, verifica-se também a pertinência das figuras infernais como instrumento crítico. Filme ${ }^{270}$, por exemplo, pode ser lido na chave da dissimulação. O personagem que busca refugiar-se do olhocâmera, e de todos os olhos que Ihe possam apreender ${ }^{271}$, dialoga com Winnie,

\footnotetext{
270 Único filme de Beckett, estrelado por Buster Keaton, 1964.

271 “... com Dias Felizes, Beckett retorna ao problema filosófico explorado no Godot e em Fim de Partida, que seria retomado em Filme: a necessidade do outro, de um outro, para
} 
quando esta execra o casal Shower (“Caiam Mortos!"), que buscam interpretála. Uma variação de confinamento, exposta na canção circular de Vladimir em Esperando Godot, e ilustrada na gravura 'Galeria de Arte' de Escher, revela embrionariamente, o modo como, na terceira fase da literatura de Beckett, os personagens 'se dividem em muitos para se fazer companhia'272. O que foi analisado em Fim de Partida, com a hipótese de Hamm ser o centro irradiador das histórias e dos demais personagens da peça, pode ser transposto para a leitura de Solo e Improviso de Ohio, mas também de textos em prosa como Company e Mal visto Mal dito.

Contudo, se as figuras infernais descerram o teatro-inferno que vige, mas vacilantemente, quando os cânones obsolescem; elas revelam também o inferno de au-delà, no qual a platéia está espelhada. Como se observou nos capítulos anteriores, Beckett inclui a audiência em seu pensamento teatral, questionando juntamente com os outros elementos dramáticos a função dos espectadores. Habituada, assim como são os personagens, a platéia, pode, no entanto, ser confrontada e estranhar-se. Mas não apenas em sua função dramática. E aqui está dada a dimensão deste inferno além-palco. Pois o estudo destas cinco peças esclarece sobre a instituição de uma nova categoria

validação". (Gontarski, S.E.; The Intent of Undoing in Samuel Beckett's Dramatic Texts, Indiana: Indiana University Press, Bloomington, 1985, p.69.)

${ }^{272}$ Company, por exemplo, novela pertencente a este período, trabalha, assim como outras obras deste terceiro momento, com dúvidas e incertezas relativas à fonte da efabulação e sua validade: De onde vêm as memórias do personagem? São mesmo suas memórias? Que voz fala? Quem ouve? Para quem são direcionadas as falas? "A fábula de outro com você no escuro. A fábula de outro fabulando de outro com você no escuro. E quão melhor no fim trabalho perdido e silêncio. E você como você sermpre foi. Só." (Beckett, Samuel; Company in The Grove Centenay Edition, vol. IV, New York: Grove Press, 2006) 
mimética, que foi anunciada por Adorno, e que também pode ser chamada de nova categoria infernal. Neste universo em que a palavra não é portadora de transformação, mas propagadora do mesmo, em que não há sujeitos, mas repetidores, em que não se convive por escolha, mas por desdita, em que a empatia decresce pelo estado completo de reificação; aí o mundo se espelha. Ou melhor - pensando na imagem de Escher como modelo do proceder beckettiano - aí o mundo se inclui. Parte da relevância do teatro de Beckett se perde, quando a crítica não considera a existência destes dois infernos conjugados - o que o presente estudo pretendeu prescrever -, infernos que não se espelham simplesmente, mas se instituem a partir de idênticas configurações. 


\section{Bibliografia}

- Adorno, Theodor W.; Teoria Estética, Lisboa: Edições 70, s/d.

$\bullet$

11, Noten zur Literatur, Frankfurt am Main: Suhrkamp, 1990.

2003.

- Adorno, T.W. e Horkheimer, Max; Dialética do Esclarecimento, Rio de Janeiro: Jorge Zahar, 1985.

- Acheson, James; Arthur, Kateyrna (editors); Beckett's Later Fiction and Drama, Hong Kong: MacMillan Press, 1987.

- Alighieri, Dante; A Divina Comédia - Paraíso, Purgatório, Inferno, tradução de Italo Eugenio Mauro, São Paulo: Editora 34, 1998.

- Alison Hale, Jane; "Endgame: How are your eyes" in Connor, Steven (editor); Waiting for Godot and Endgame, Hong Kong: The McMillan Press, 1993.

- Anders, Günther; L'Obsolecence de l'Homme: sur l'âme à l'époque de la deuxiéme Révolution Industrielle, Paris: L'Encyclopédie de Nuisances, Ivrea, 2002.

- Andrade, Fábio de Souza; Samuel Beckett: O Silêncio Possível, São Paulo: Ateliê, 2001.

- Angel-Perez, Élisabeth; Voyages au Bout du Possible: Les Théatres du Traumatisme de Samuel Beckett à Sarah Kane, Langres: Klincksieck, 2006.

- Aristóteles, Poética, Lisboa: Imprensa Nacional, Casa da Moeda, 1986.

- Auerbach, Erich; Mimesis, São Paulo: Perspectiva, 1976.

- Auster, Paul; A Arte da Fome E outros Ensaios, Rio de Janeiro: José Olympio, 1996.

- Badiou, Alain; Beckett: l'increvable désir, Paris: Hachette, 1995. 
- Beall, J.C. (editor), Liars and Heaps - New Essays on Paradox, Oxford: Clarendon Press, 2003.

- Beckett, Samuel; The Grove Centenary Edition, vols. I, II, III, IV, New York: Grove Press, 2006.

; The Complete Dramatic Works, London: Faber Paperbacks, 1990.

$\bullet$ ; Esperando Godot, tradução de Flávivo Rangel, São Paulo: Abril Cultural, 1976.

$\bullet$ Esperando Godot, tradução de Fábio de Souza Andrade, São Paulo: Cosac\&Naify, 2005.

$\bullet$

-

Cosac\&Naify, 2002.

$\bullet$

-

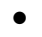

Suhrkamp, 2001
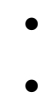

$\bullet$

-

$$
\text { - }
$$$$
\text { - }
$$$$
\text { - }
$$$$
\text { - }
$$$$
\text { - }
$$$$
\text { - }
$$$$
\text { - }
$$$$
\text { - }
$$$$
\text { - }
$$$$
\text { - }
$$$$
\text { - }
$$$$
\text { - }
$$$$
\text { - }
$$$$
\text { - }
$$$$
\text { - }
$$$$
\text { - }
$$
Warten Auf Godot, Frankfurt: Suhrkamp, 2003. ; En Attendant Godot, Paris: Minuit, 1990.

; Fim de Partida, tradução de Fábio de Souza Andrade, São Paulo: ; Fin de Partie, Paris: Minuit, 2004. ; Endspiel. Fin de Partie. Endgame, Frankfurt: Suhrkamp, 1996. ; Glückliche Tage, Happy Days, Oh les beaux jour, Berlin: ; La Dernière Bande, Paris; Minuit, 1990.

; Eu Não, São Paulo: Olavobrás, s/d.

; Catastrophe Et Autres Dramaticules, Paris: Minuit, 2005.

; Comédie et Actes Divers, Paris: Édition de Minuit, 1990.

; Oh les Beaux Jours, Paris: Minuit, 1963.

; Pavesas, Barcelona: Tusquets, 2000.

; Eleutheria, Barcelona: Tusquets, 1996.

; Como É, São Paulo: lluminuras, 2003.

; Molloy, Rio de Janeiro: Nova Fronteira: 1988.

; Malone Morre, São Paulo: Brasiliense, 1986.

; O Inominável, Rio de Janeiro: Nova Fronteira, 1989.

; El Innombrable, Barcelona: Lumen, 1966.

; Murphy, Paris: Minuit, 1997.

; Watt, Paris: Minuit, 2005.

; Mercier et Camier, Paris: Minuit, 2003.

; Primeiro Amor, Rio de Janeiro: Nova Fronteira, 1987.

; Primeiro Amor, São Paulo: Cosac\&Naify, 2004.

; Nouvelles et Textes pour Rien, Paris: Minuit, 2003.

; Detritus, Barcelona: Tusquets, 2001.

; Mal Vu Mal Dit, Paris: Minuit, 2002. 
-

$\bullet$

$\bullet$

$\bullet$ 2003.

; Têtes-Mortes, Paris: Minuit, 2004.

; Relatos, Barcelona: Tusquets, 2003.

; Pioravante Marche, Lisboa: Gradiva, 1988.

; Proust, tradução de Arthur Nestrovski, São Paulo: Cosac\&Naify,

; 'Dante...Bruno. Vico...Joyce'; in Riverrun, Ensaios sobre James Joyce, Rio de Janeiro: Imago, 1992.

$\bullet$ ; Le Monde et Le Pantalon, Paris: Minuit, 2003.

$\bullet$ ; Poèmes, Paris: Minuit, 2002.

- Berkeley, George; Dos Princípios do Conhecimento Humano, 1,3, in Pensadores: Berkeley, Hume, São Paulo: Abril, 1984.

- Berretini, Célia; A Linguagem de Samuel Beckett, São Paulo: Perspectiva, 1977.

$\bullet$ ; Samuel Beckett: Escritor Plural, São Paulo: Perspectiva, 2004.

- Blanchot, Maurice; "Où maintenant? Qui maintenant?", in Le Livre à Venir, Paris: Gallimard, 1959.

; O Livro por Vir, São Paulo: Martins Fontes, 2005.

- Bloom, Harold; O Cânone Ocidental, Rio de Janeiro: Objetiva, 1994.

- Boxall, Peter (editor); Samuel Beckett: Waiting for Godot, Endgame, Cambridge: Icon Books, 2000.

- Breuer, Rolf; "Paradox in Becketf" in The Modern Language Review, vol.88, n.3, pp.559-580, (Jstor).

- _ _ _ Samuel Beckett - Eine Einführung, München: Wilhelm Fink, 2005.

- $\quad$ Buck-Morss, Susan; Origin of Negative Dialectics, New York: Free, 1979.

- Buning, Marius ; Oppenheim, Lois (editors); Beckett in the 1990s. Selected papers from the Second International Beckett Symposium, held in The Hague, 8-12 April, Atlanda/Amsterdam : Rodopi, 1993.

- Bürger, Peter ; Teoria da Vanguarda, São Paulo : Cosac\&Naify, 2008.

- Burkman, Katherine H. (editor); Myth and Ritual in the Plays of Samuel Beckett, Associated University Presses, 1987. 
- Calderón de La Barca, Pedro ; A Vida é Sonho, traduzido por Renata Pallottini, São Paulo: Página Aberta, 1992.

- Carlson, Marvin; Teorias do Teatro, São Paulo: UNESP, 1997.

- Caselli, Daniela; Beckett's Dantes: Intertextuality in the Fiction and Criticism, Manchester/New York: Machester University Press, 2005.

- Cavalcanti, Isabel; Eu que não estou aí onde estou: o teatro de Samuel Beckett, Rio de Janeiro: 7Letras, 2006.

- Cerrato, Laura; Génesis de la Poética de Samuel Beckett, Buenos Aires: Fondo de Cultura Económica, 1999.

- Clément, Bruno; L'Oeuvre sans Qualités: Rhétorique de Samuel Beckett, Paris: Seuil, 1994.

- Cohn, Ruby; Samuel Beckett: The Comic Gamut, New Jersey: Rutgers University Press, 1962.

- _ (editor); Samuel Beckett: a collection of criticism, Várias cidades: McGraw-Hill Book Company, s/d.

- Connor, Steven; Repetition, Theory and Text, Oxford: Basil Blackwell, 1988.

- Costa, Iná Camargo; Sinta o Drama, Petrópolis: Vozes, 1998.

- Debord, Guy; A Sociedade do Espetáculo, Rio de Janeiro: Contraponto, 1997.

- Deleuze, Gilles; "L'Épuisé" in Beckett, Samuel; Quad et Trio du Fantôme, ...que nuages..., Nacht und Träume, Paris: Minuit, 1990.

- Diderot, Denis; Discurso Sobre A Poesia Dramática, São Paulo: Brasiliense, 1986.

- Descartes, René; Obra Escolhida, tradução de J. Guinsburg e Bento Prado Júnior, São Paulo: Difel, 1973.

$\bullet$

- Domenach, Jean-Marie; Le Retour du Tragique, Paris: Seuil, s/d.

- Ernst, Bruno; O Espelho Mágico de Escher, Coréia do Sul: Taschen, 2007. 
- Esslin, Martin; O Teatro do Absurdo, Rio de Janeiro: Zahar, 1968.

- Godeau, Florence; Récits en Souffrance, Paris: Kimé, 2001.

- Gontarski, S.E.; The Intent of Undoing in Samuel Beckett's Dramatic Texts, Indiana University Press, Bloomington, 1985.

(editor); Theatrical Notebooks of Samuel Beckett: Endgame, London: Faber and Faber, 1992.

- Gontarski, S.E. e Ackerley, C.J.; The Grove Companion To Samuel Beckett - A reader's guide to his works, life, and thought, New York: Grove, 2004.

- Graver, Lawrence; Beckett - Wainting for Godot, Cambridge: University Press, 1999.

- Guinsburg, J. (org.); Pirandello, do Teatro no Teatro, São Paulo: Perspectiva, 1999.

- Harmon, Maurice (editor); The Correpondence of Sameuel Beckett and Alan Schneider, London/Cambridge: Harvard University Press, 1999.

- Hawkins, Peter S. e Schoter, Anne Howland; Ineffability: Naming the Unnamable from Dante to Beckett, New York, AMS Press, 1984.

- Hegel, G. W. Friedrich; Curso de Estética - O Belo na Arte, São Paulo: Martins Fontes, 1998.

- Henz, Alexandre de Oliveira; Estéticas do Esgotamento: Estratos Para uma Política em Beckett e Deleuze (tese, mimiografada), São Paulo, 2005.

- Jacquart, Emmanuel; Le Theatre de Dérision, Paris: Gallimard, 1998.

- Janvier, Ludovic; Beckett par Lui-Même, Paris: Éditons du Seuil, 1969.

- Jay, Martin; Adorno, Harvard University Press, 1984.

- Keefe, Rosanna, Smith, Peter (editors); Vagueness: A Reader, Cambridge, London: MIT Press, 1997.

- Kenner, Hugh; Samuel Beckett: A Critical Study, London: John Calder, 1962.

- _ ; A Reader's Guide to Samuel Beckett, Syracuse: Syracuse University Press, 1996. 
Dalkey Archive Press, 2005.

- Kern, Edith ; Existential Thought and Fictional Technique, New Haven, London: Yale University Press, 1970.

- Knowlson, James; Damned to Fame, Londres: Bloomsbury, 1997.

$\bullet$ (editor); The Theatrical Notebooks of Samuel Beckett - Krapp's Last Tape, London: Faber and Faber, 1992.

Lightness and Darkness in the Theatre of Samuel Beckett, London: Turret Books, 1972

- Kowlson, James e Mcmillan, Douglas (editors); The Theatrical Notebooks of Samuel Beckett - Waiting for Godot, New York, Groove Press, 1994.

- Kott, Jan ; Shakespeare nosso Contemporâneo, São Paulo : Cosac\&Naify, 2003.

- Lawley, Paul; "Stages of Identity: from Krapp's Last Tape to Play" in Pilling, John (editor), The Cambridge Companion to Beckett, Cambridge: Cambridge University Press, 1996.

- Leopoldo e Silva, Franklin ; Descartes - A Metafísica da Modernidade, São Paulo : Moderna, 2005.

- Locatelli, Carla; Unwording the world: Samuel Beckett's Prose Works after the Nobel Prize, Philadelphia: University of Pennsylvania Press, 1990.

- Lukàcs, Georges; La Théorie du Roman, Genève: Éditions Gonthier, 1963.

- Margarit, Lucas; Samuel Beckett: Las Huellas en el Vacío, Buenos Aires: Atuel, Avispa, 2003.

- Megged, Matti; Dialogo nel Vuoto, Hestia, 1995.

- Morot-Sir, Edouard; Harper, Howard; McMillan III, Dougald (editors); Samuel Beckett: The Art of Rhetoric, Valencia: Chapel Hill, 1976.

- Morrison, Kristin; Canters and Chronicles: The Use of Narrative in the Plays of Samuel Beckett and Harold Pinter, Chicago: The University of Chicago Press, 1986. 
- O'Hara, J.D.; Twentith Century Interpretarions of Molloy, Malone Dies, The Unnamable, USA: Prentice-Hall, Englewood Cliffs, 1958.

- Pavis, Patrice; Dicionário de Teatro, São Paulo: Perspectiva, 1999.

- Pasta Jr., José Antônio; "Apresentação" in Szondi, Peter; Teoria do Drama Moderno, São Paulo: Cosac\&Naify, 2001.

- Piacentini, Gérard; Samuel Beckett mis à nu par ses auteurs, même: Essai sur le théâtre de Samuel Beckett, Mayenne, Nizet, 2006.

- Pilling, John; Bryden, Mary; The ideal core of the onion: Reading Beckett Archives, Bristol: The Longdunn Press, 1992.

- Pilling, John (editor); The Cambridge Companion to Beckett, Cambridge: University Press, 1993.

- Plimpton, George (org.); Playwrights at Work, New York: Modern Library, 2000.

- Pirandello, Luigi; O Falecido Mattia Pascal. Seis Personagens à Procura de um Autor, São Paulo: Abril Cultural: 1978.

- Rabinovitz, Rubin; "Beckett, Dante, and the Metaphorical Representation of Intangible Reality" in Alan W. Friedman, Charles Rossman, Dina Sherzer (editors); Beckett Translation/Translating Beckett, University Park: Pennsylvania State University Press, 1987,

- Ramos, Luiz Fernando; O Parto de Godot e outras encenações imaginárias: a rubrica como poética da cena, São Paulo: Hucitec/ Fapesp, 1999.

- Reynolds, Corina J.; Teatro Irlandes, Madrid: Editora Nacional, s/d.

- Ricks, Christopher; Beckett's Dying Words, Oxford: Oxford University Press, 1995.

- Rosenfeld, Anatol; O Teatro Épico, Rio de Janeiro: Buriti, 1965.

- Ryngaert, Jean-Pierre; Lire en Attendant Godot de Beckett, Paris Dunod, 1993.

- Scherer, Jacques; La Dramaturgie Classique en France, Mayenne: Nizet, 1997. 
- Sextus Empiricus; Outlines of Pyrrhonism, London: Harvard University Press, 1993.

- Staiger, Emil; Conceitos Fundamentais da Poética, Rio de Janeiro: Tempo Brasileiro, 1993.

- Szondi, Peter; Teoria do Drama Moderno [1880-1959], tradução de Luiz Sérgio Rêpa, São Paulo: Cosac\&Naify, 2001.

- _ _ _ Teoria del Drama Moderno / Tentativa sobre lo Trágico, Barcelona: Destino, 1994.

- Williams, Raymond; Drama in Performance, Philadelphia: Open University Press, 1995.

- _ _ _ _ Tragédia Moderna, São Paulo: Cosac\&Naify, 2002.

- _ _ _ El Teatro de Ibsen a Brecht, Barcelona: Península, 1975.

- _ _ _ _ "Formas", in Cultura, Rio de Janeiro: Paz e Terra, 1992.

- Wood, Rupert; "An Endgame of Aesthetics: Beckett as essayst" in Pilling, Joe (editor); The Cambridge Companion to Beckett, Cambridge: Cambridge University Press, 1993.

- Worth, Katharine; The Irish Drama of Europe from Yeats to Beckett, New Jersey: Humanities Press, 1978.

- Worton, Michael; "Waiting for Godot and Endgame" in Pilling, John (editor), The Cambridge Companion to Beckett, Cambridge: Cambridge University Press, 1996.

- Zeller, Patricia; Beckett's Cartesian Dilemma, tese (mimiografada), 1979.

- Zuidervaart, Lambert; Adorno's Aesthetic Theory - The redemption of illusion, Massachusetts: MIT, 1994.

- Zurbrugg, Nicholas; Beckett and Proust, New Jersey: Barnes and Noble, 1988.

- Cahier de l'Herne: Samuel Beckett, Édition de l'Herne, 1976.

- Les Critiques de Notre Temps et Beckett, Paris: Garnier, 1971.

- Revue d'Esthetique (hors série), Paris: Jean Michel Place, 1990.

- Europe - Revue Littéraire Mensuelle (770-771), Paris, 1993. 
- Critique (519-520), Paris: Minuit, 1990. 